\title{
Observações sobre fauna e flora na "Relação da Viagem, que fez o Conde da Azambuja da cidade de S. Paulo para a Villa do Cuyabá no anno de 1751" (cod-546 da Biblioteca Nacional de Portugal)
}

\author{
Nelson Papavero ${ }^{12}$ \\ 1 Universidade de São Paulo (USP), Museu de Zoologia (MZUSP). São Paulo, SP. Brasil. E-mail: pavotnel@gmail.com. \\ 2 Pesquisador Sênior do Conselho Nacional de Desenvolvimento Científico e Tecnológico (CNPq).
}

\begin{abstract}
Antônio Rolim de Moura, Conde de Azambuja (1709-1792), was appointed in 1748, by his cousin, the king of Portugal D. João V, as Governor of the Captaincy of Mato Grosso. He arrived in Brazil (Recife) in April 1749, heading in June to Rio de Janeiro. In the beginning of 1750 he was in the city São Paulo. From April $1^{\text {st }}$ to May $1^{\text {st }}$ he undertook a short trip to Parati, in the state of Rio de Janeiro. Returning to São Paulo he occupied himself with the preparatives for the adventurous fluvial voyage to Cuiabá (Mato Grosso). Embarking on August $5^{\text {th }}$, he arrived in Cuiabá on January 12, 1751. In that same year he wrote a relation of his voyage addressed to $D$. João $\mathrm{V}$, narrating the dangers and vicissitudes of the undertaking, with comments about the regions covered, animals, plants and Indians. That manuscript (cod-546), now in the Biblioteca Nacional de Portugal, is here transcribed and commented.
\end{abstract}

Key-Words. Antônio Rolim de Moura; Conde de Azambuja; Biography; Trip to Parati; Fluvial voyage from São Paulo to Cuiabá; Vicissitudes of navigation; Animals; Plants; Indians; MS in the Biblioteca Nacional de Portugal (cod-546).

\begin{abstract}
Resumo. Antônio Rolim de Moura, Conde de Azambuja (1709-1792), foi nomeado em 1748 por seu primo, o rei de Portugal, D. João V, Governador da Capitania de Mato Grosso. Chegou ao Brasil (Recife) em abril de 1749, dirigindo-se em junho ao Rio de Janeiro. No início de 1750 chegou a São Paulo. De $1^{\circ}$ de abril a $1^{\circ}$ de maio desse ano fez uma viagem a Parati, no estado do Rio de Janeiro. Regressando à cidade de São Paulo ocupou-se com os preparativos para a aventurosa viagem fluvial até Cuiabá (Mato Grosso). Embarcou a 5 de agosto, chegando em Cuiabá aos 12 de janeiro de 1751. Ainda nesse ano escreveu o relato de sua viagem, dirigido a D. João V, narrando os perigos e vicissitudes da empresa e tecendo comentários sobre as regiões percorridas, animais, plantas e índios. Esse manuscrito (cod-546), atualmente na Biblioteca Nacional de Portugal, é aqui transcrito e comentado.
\end{abstract}

Palavras-Chave. Antônio Rolim de Moura; Conde de Azambuja; Biografia; Viagem a Parati; Viagem fluvial de São Paulo a Cuiabá; Vicissitudes da navegação; Animais; Plantas; Índios; MS na Biblioteca Nacional de Portugal (cod-546).

\section{INTRODUÇÃO}

Antônio Rolim de Moura' (Fig. 1) nasceu na Vila de Moura, no Baixo Alentejo, no ano de 1709. Foi seu pai D. Nuno de Mendonça, IV Conde de Val de Reis, senhor de Póvoa e de Meadas, Comendador e Alcaide-Mor das Comendas e Alcaidarias. Sua mãe foi D. Leonor de Noronha, filha do I Marquês de Angeja, D. Pedro de Noronha. Por linha de varonia, vinha da família antiquíssima e nobilíssima dos Mendonças, apesar de não ter usado o nome, por sucessão à casa dos Azambujas, por ter o último varão renunciado o nome da família. Desde cedo, o futuro Governador de Mato Grosso foi dado aos estudos. Aplicado nas Filosofias, leitor dos escritos bíblicos e teológicos, das Matemáticas puras, Ciências e Artes mais úteis. E ainda, estudou os princí-

1 Moura (1982) publicou uma biografia do Conde de Azambuja. 


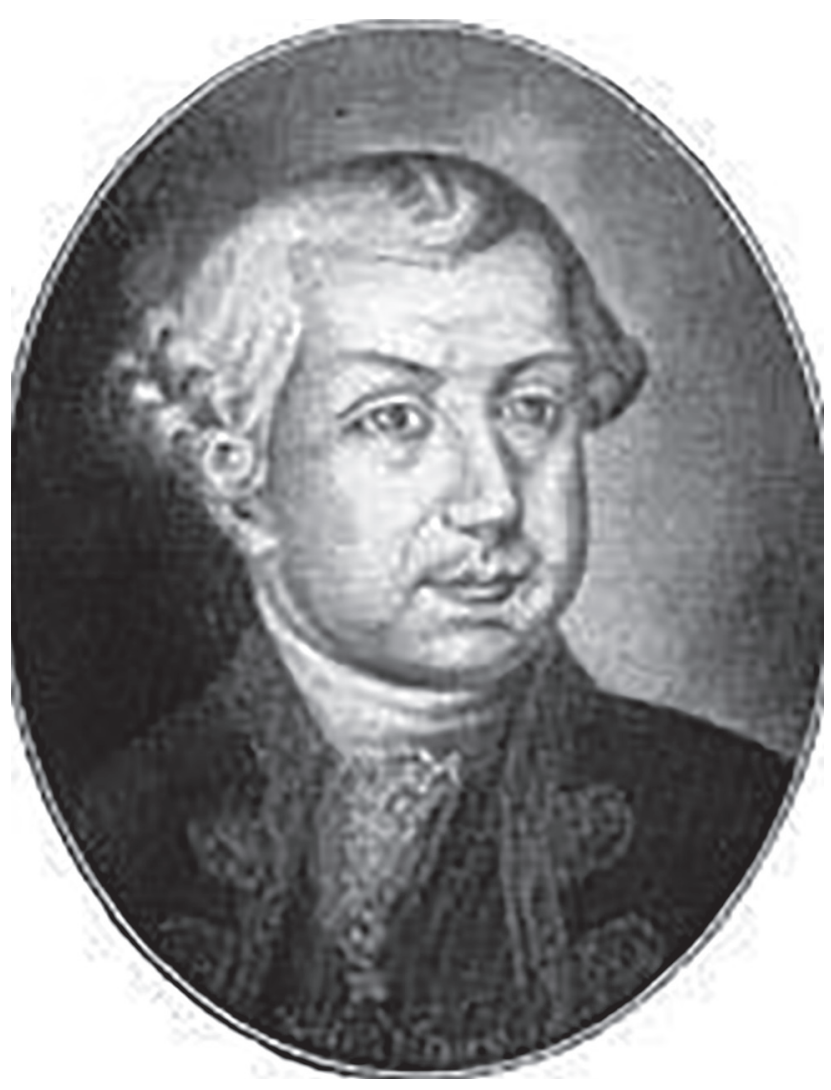

Figura 1. Antônio Rolim de Moura, Conde e Azambuja.

pios da Mecânica, Estática, Hidráulica, Marinha, Pilotagem e Fortificação. Era aplicado às leituras da História Universal e da História de Portugal e se aperfeiçoara na arte da Retórica.

Ao tratar das qualidades políticas do futuro governador, o rei D. João V (1748) deixa em seu parecer considerações sobre seus merecimentos e serviços e a que dará inteira satisfação a tudo o que lhe for encarregado e escreve com o fim de nomeá-lo para tão nobre função: Hey por bem nomeallo Governador, e Capitão General da Capitania do Mato Grosso por tempo de três annos.

Rolim de Moura embarcou em Lisboa em fevereiro de 1749 e dois meses depois chegou a Pernambuco. Dali, em junho, continuou para o Rio de Janeiro. Só no início do ano seguinte dirigiu-se a São Paulo para organizar sua monção² e depois partir com destino a Cuiabá (Canova, 2008a: 80-81).

O caminho seguido pelo Conde de Azambuja corresponde ao " $2^{\circ}$. roteiro" representado na figura abaixo 3 (Fig. 2).

Chegou à Vila Real do Bom Jesus do Cuiabá apenas em 12 de janeiro de 1751, tomando posse do cargo de Governador a 17 do mesmo mês. Permaneceu nesse cargo até $1^{\circ}$ de dezembro de 1765 . De sua atuação destacou-se pela garantia da posse e da expansão dos domínios da Coroa portuguesa na fronteira oeste, tendo priorizado o povoamento e a defesa da região, especialmente dos ataques espanhóis. Nas instruções governativas em 1749, a rainha Dona Maria Ana de Áustria diz: Por se ter entendido que Mato Grosso é a chave do propugnáculo do sertão do Brasil pela parte do Peru.... Com isso, ela incumbe D. Antonio Rolim de Moura de construir uma Vila-Capital que plantasse definitivamente as bases do domínio português sobre o novo território do Extremo Oeste, articulando o comércio com a Metrópole e assegurando a posse da região mais indefinida de toda a colônia (Canova, 2008a: 79).

A 3 de novembro de 1751, D. Antonio Rolim de Moura partiu para as minas ao norte de Mato Grosso. A 7 de dezembro chegou ao Guaporé e no dia 14 do mesmo mês estava no sítio de Pouso Alegre, o lugar em que seria fundada a futura Vila Bela da Santíssima Trindade (Figs. 3 e 4), a primeira Vila-Capital de Mato Grosso, erigida a essa condição, em 19 de março de 1752, na margem direita do Guaporé. Nesse dia de festividade cristã, o do Patriarca São José, Rolim de Moura fundou a cabeça de governo na fronteira, lugar mais próximo do Guaporé e entre os seus dois principais afluentes (Sararé e Galera) e sua escolha, o sitio de Pouso Alegre. A Vila-Capital foi erigida em terreno alagadiço, pois o rio Guaporé costumava derramar água em tempos de cheia. Porém, o lugar foi estrategicamente pensado e sua edificação consolidou o início da ocupação lusitana no extremo oeste da América portuguesa. Ali, em Vila Bela, passou a administrar a Capitania e muito

2 As chamadas monções foram expedições fluviais que, entre a segunda década do século XVIII e a primeira metade do século XIX, mantiveram contato entre a capitania de São Paulo e a capitania de Mato Grosso. Monção é uma palavra de origem árabe (مسوم mausin, que significa "estação do ano em que se dá determinado fato") e é como se chamam os ventos característicos do Sudeste Asiático. No Brasil, a nomeação foi escolhida por determinar o período entre o final de março e o início de junho, quando acreditavam ser a melhor época para uma expedição (que passou a ser denominada monção) pelo Tietê e outros rios, quando o nível de suas águas era maior. A descoberta de ouro nas regiões do rio Cuiabá foi o que impulsionou as navegações que aumentaram a comunicação com Mato Grosso. Taunay (1953) fez uma excelente compilação dos relatos monçoeiros.

3 Um bom resumo desse trajeto foi publicado por Barbosa ([1792] 1843). 


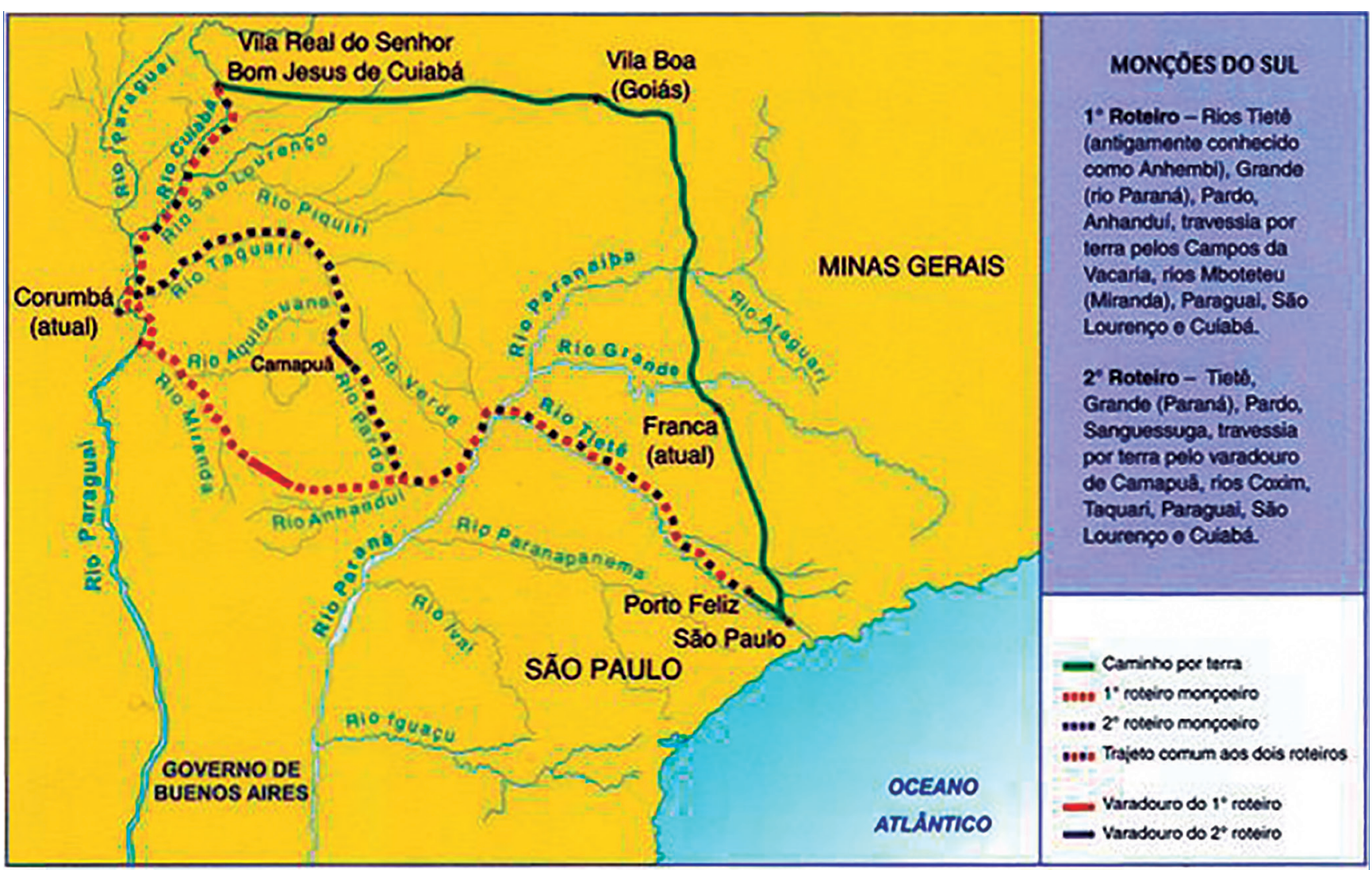

Figura 2. Segundo roteiro das monções, por Camapuã (https://cuiabanidade1.wordpress.com/as-moncoes/os-rios).

se correspondeu com os seus superiores. A Vila no princípio era apenas sinalizada por um tronco de piúva, que servia de pelourinho. Fincado no meio do descampado, esse tronco apresentava-se como um marco da futura praça. Rolim de Moura aguardou até o dia de São José, para constatar o nível da cheia do rio e fundou, enfim, Vila Bela, convocando autoridades, homens bons e o povo para levantarem o pelourinho. Antes de sua vinda, ali se achavam apenas uns ranchinhos construídos no barranco do rio, lugar onde os pescadores faziam seus postos quando vinham às pescarias. Entretanto, passados cinco anos, observou-se certo crescimento. Na borda do rio se fez a capela de palhoça. Já no primeiro ano foi destruída pela força das águas, quando o rio Guaporé saiu de sua madre e arruinou aquela que seria a primeira capela da Vila-Capital. Foi então que Rolim obrigou-se a edificar outra, essa construída na praça principal a custa da Real Fazenda, porque para fazê-la a despesa só do povo da vila seria encargo demasiado, além de afugentá-lo, ao mesmo tempo em que se tentava por todos os meios e empenho, atraí-lo para o Guaporé. A estrutura da Vila aumentou e em torno da praça central distribuíam-se os edifícios públicos, tais como a matriz, a Casa da Câmara, a Cadeia, a Casa de Fundição, a Real Fazenda. A Igreja da Matriz abrigava duas capelas, a de Santo Antônio e a Nossa Senhora Mãe dos Homens. Nos cinco primeiros anos de investimento na capital foram construídas trinta e quatro casas cobertas de telhas e outras trinta mais ou menos cobertas de capim. Na vila e nos arredores, existiam vinte e tantas roças entre grandes e pequenas. As pessoas de confissão, segundo contagem feita pelo vigário, chegavam a setecentas, "pessoas de todas as qualidades". Nos arredores da Vila se achavam vários engenhos de farinha de milho, mandioca, açúcar, aguardente, melados, "com o que vai se aprofundando as raízes da vila", segundo observações do governador. Outro dado significativo sobre a região foi a criação de bovinos e de carneiros, que também se avolumava significativamente (Canova, 2008a: 81, 82-83).

Durante o seu governo, Rolim de Moura expulsou os missionários espanhóis da margem direita do rio Guaporé, estabeleceu uma política de incorporação das populações indígenas ${ }^{4}$, e teve" ainda importante papel na criação da Companhia Geral do Grão-Pará e Maranhão; abriu estradas para o Maranhão e Bahia, e foi o iniciador da cultura de açúcar com fins comerciais e industriais.

Em 1751 redigiu a Relação da viagem que fez, de São Paulo a Cuiabá (Fig. 5), dirigida ao rei de Portugal D. João V, manuscrito atualmente depositado na Biblioteca Nacional de Portugal (cod-546), que é aqui transcrito em leitura diplomática ${ }^{5}$. Em 1754 apareceu em Lisboa outro relato dessa aventura, de conteúdo muito diferente, a Relaçaõ da chegada, que teve a gente do Mato Groço, em companhia do senhor D. Antonio Rolim desde o porto de Araritaguaba, até á esta Villa Real do Senhor Bom Jesus do Cuyaba (Anôn., 1754) [Ver Apêndice abaixo].

4 Sobre suas relações com os índios, ver Canova (2008b, 2016).

5 Esse manuscrito foi editado, mas não com a grafia original, por Varnhagen (1846) e Vilhena (1935; este reproduzido em Anôn., 1977: [81]-137]. Sobre essa viagem, cf. também Canova (2010, 2011). 


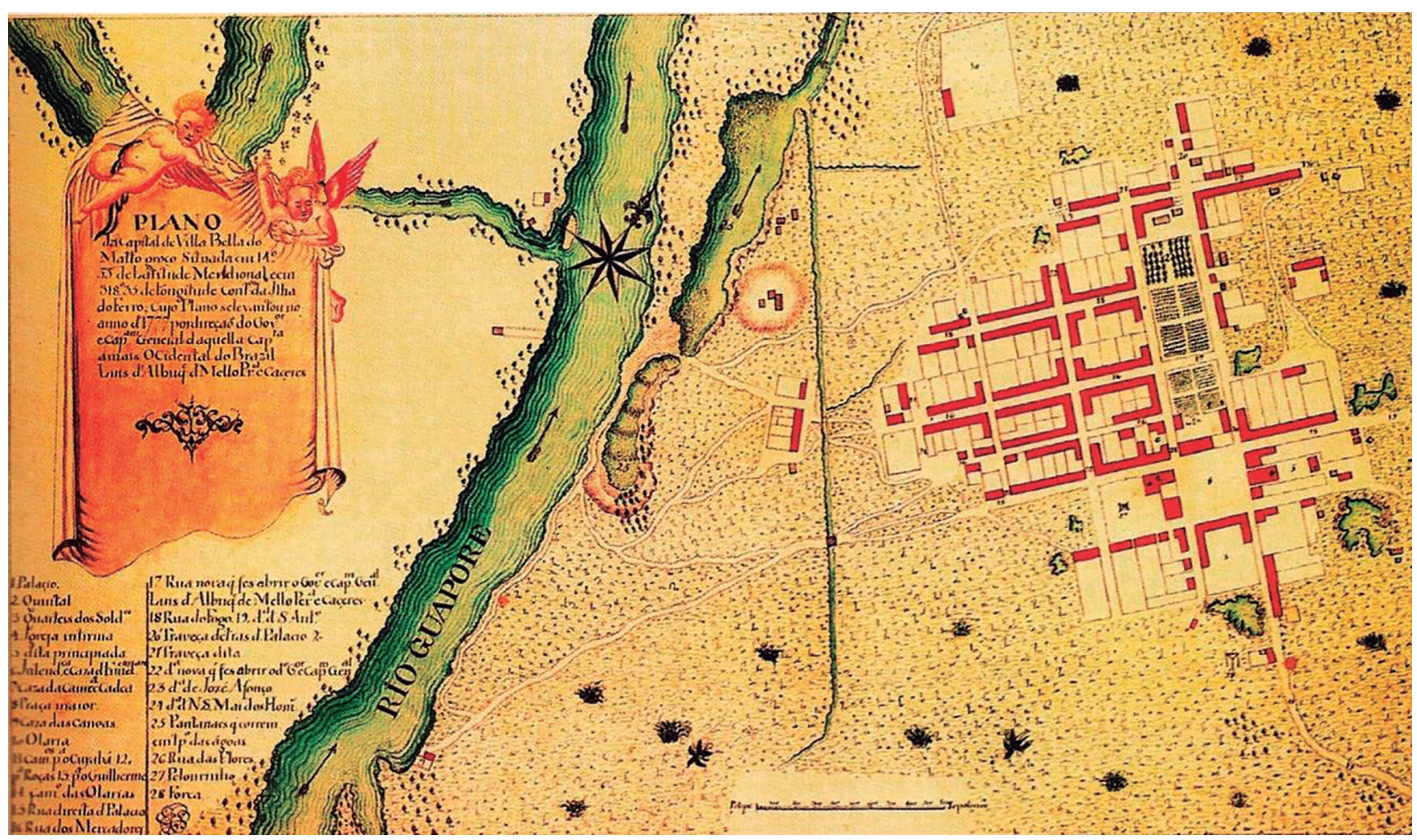

Figura 3. A Vila Bela da Santíssima Trindade em 1777.

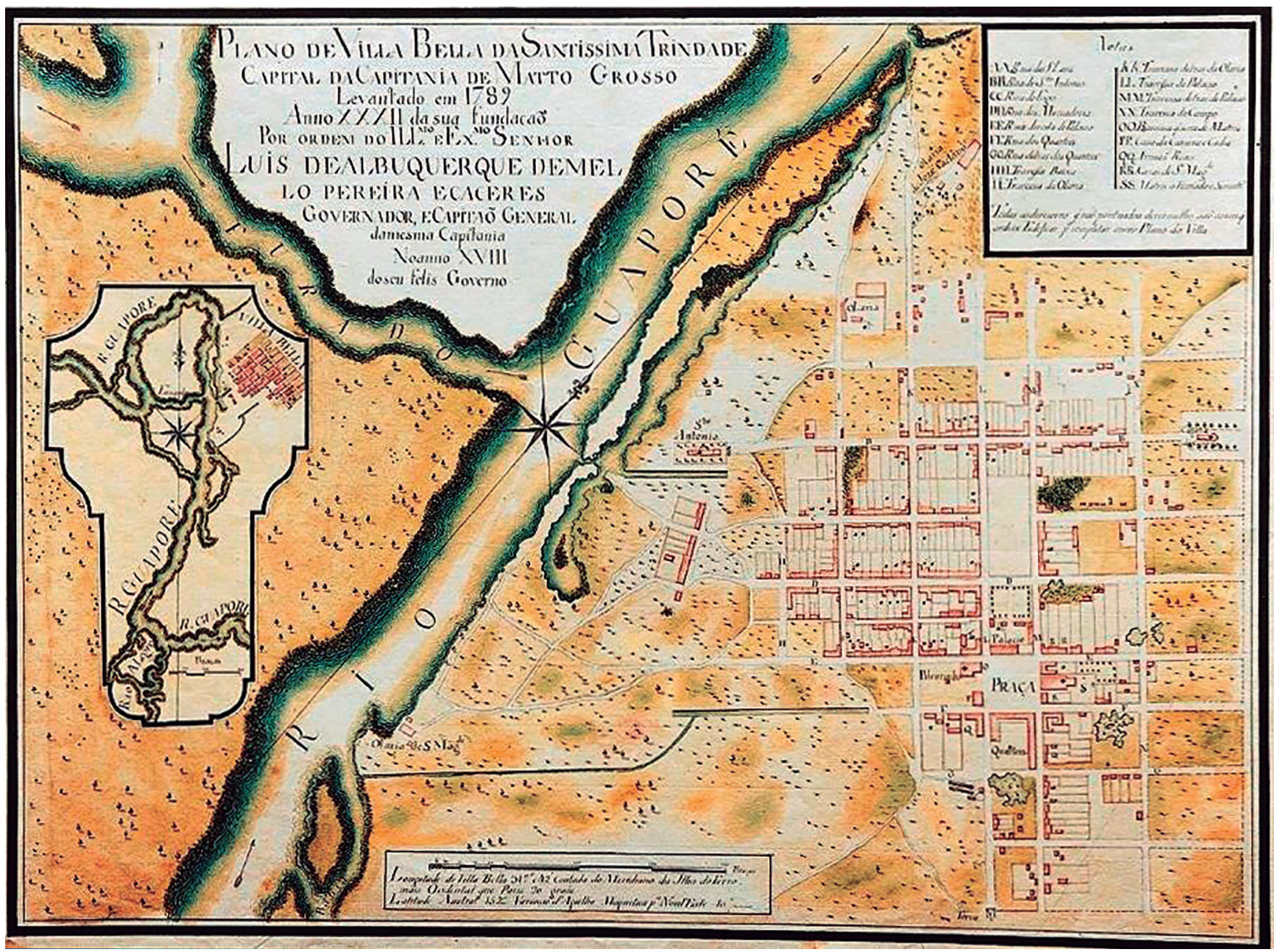

Figura 4. A Vila Bela da Santíssima Trindade em 1787. 


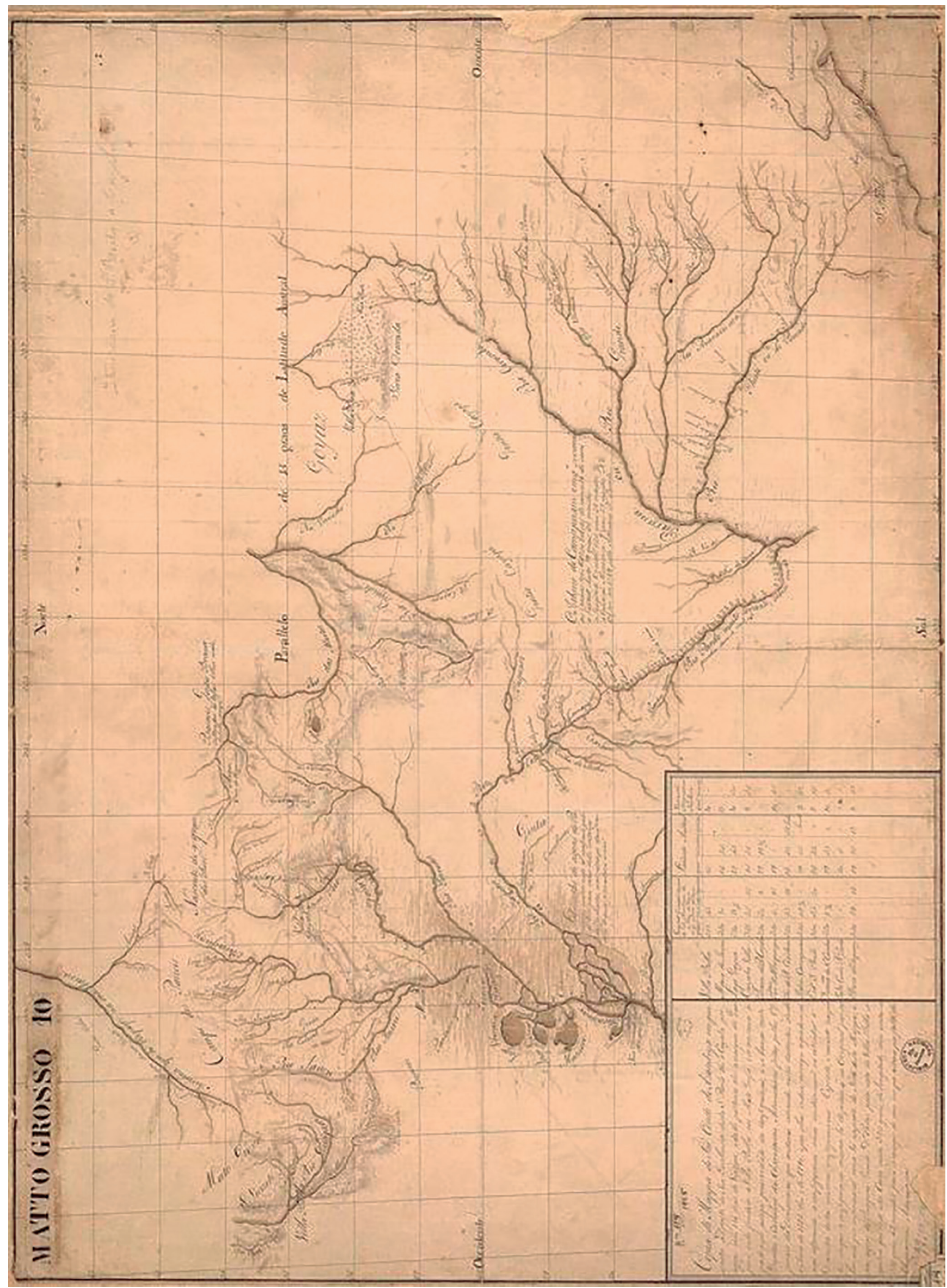

Figura 5. Copia do Mappa do snr. Conde de Azambuja em que se nota a derrota de sua Excellencia desde S. Paulo thé o Cuyaba por agoas com 114 dias de viagem, edalhi por terra the a margem do Guaporé onde fundou a Villa Bella em Mato Grosso (Biblioteca Nacional do Rio de Janeiro; desenho a tinta ferrogálica e a nanquim; $48,2 \times 64,3 \mathrm{~cm}$ em f. $51,1 \times 66,3)$ 
Em 1763 Rolim de Moura recebeu do rei de Portugal D. José I o título de conde de Azambuja ${ }^{6}$ e em 15 de fevereiro de 1765 partiu de Mato Grosso em direção à Bahia, pela rota do Pará. Entregou o seu posto ao seu sobrinho e sucessor João Pedro da Câmara. Sofrendo de surdez, vertigens, papadas, obstruções e ainda pobre e empenhado, dirigiu-se à Bahia para mais uma aventura política, exercer a função de governador (1766-1767), uma obrigação vassálica do comando imperial de D. José I (Canova, 2008a: 85).

Assumiu depois os cargos de Vice-Rei do Estado do Brasil e Governador do Rio de Janeiro (17 de novembro de 1767 4 de novembro de 1769). Ao tomar posse do cargo de Vice-Rei, no Rio de Janeiro, foi saudado com uma Falla que no feliz dia 17 de Novembro de 1767 em que tomou posse do governo desta capitania do Rio de Janeiro o il. ${ }^{\text {mo }}$ e exc. ${ }^{\text {mo }}$ senhor $D$. Antonio Rolim de Moura Conde de Azambuja, do Conselho de Sua Magestade Fidelissima... Vice-Rei, e Capitaõ General do Mar, e Terra do Estado do Brasil... offerece ao mesmo senhor em nome de todo o corpo da Relação o doutor Manoel Francisco da Silva e Veiga Desembargador de Agravos, e Juiz Intendente do Real Confisco (Veiga, 1769: 35-64).

Retornou a Portugal em 1769, onde foi nomeado presidente do Conselho da Fazenda (1770), governador das Armas de Lisboa e da Província da Estremadura (1789), e vedor da rainha.

Foi sócio da Academia Real das Ciências, classe de ciências de cálculo.

Morreu em Lisboa, Portugal, em 8 de dezembro de 1782. 
LEITURA DIPLOMÁTICA DO MANUSCRITO

Fólio $1 \mathrm{r}$

Relaçaõ

Da

\section{Viagem, que fez}

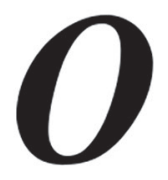

Conde da Azambuja Da Cidade de

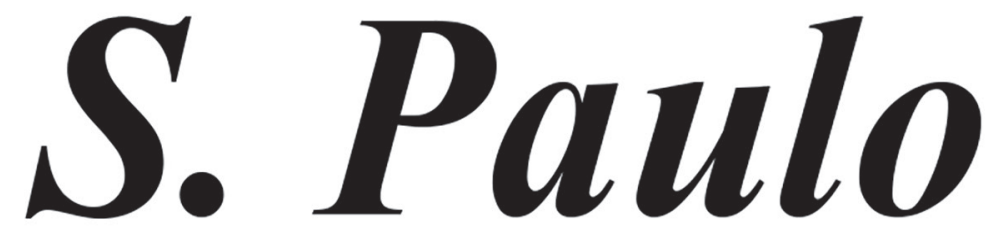

Para a Villa do

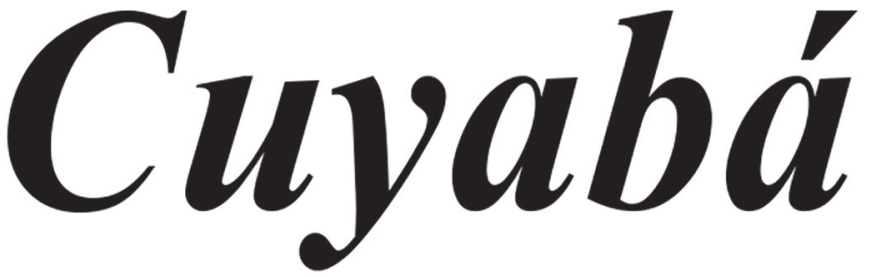

No anno de $\underline{1751}$ 


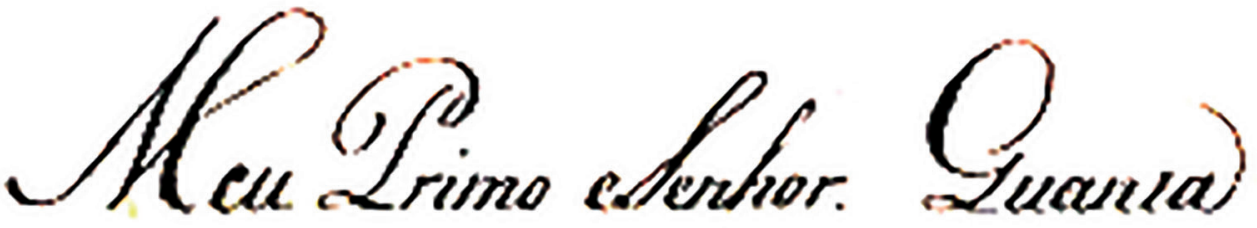

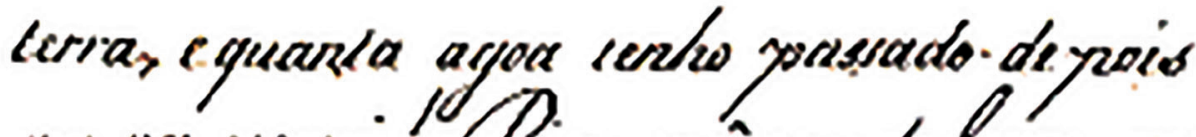

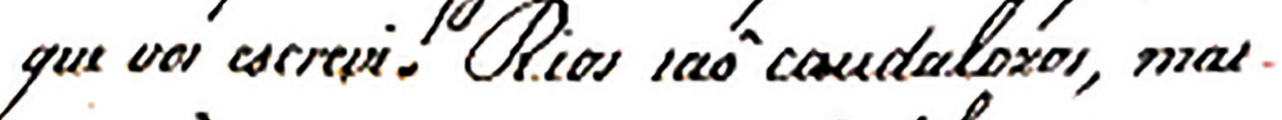
101,100 cspresson, c crumper $100 \hat{0}$ dilnuades, que

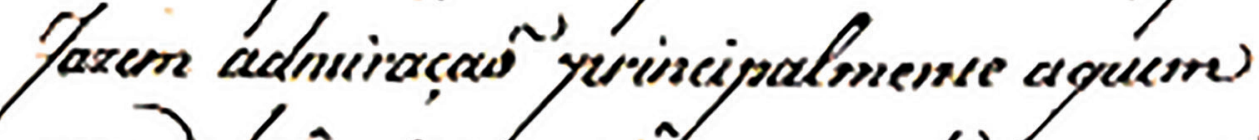

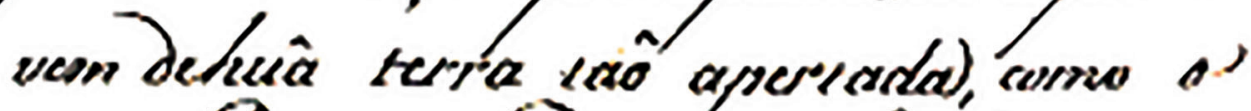
vaber ordenar sude, quarero pacessei, sui, ol

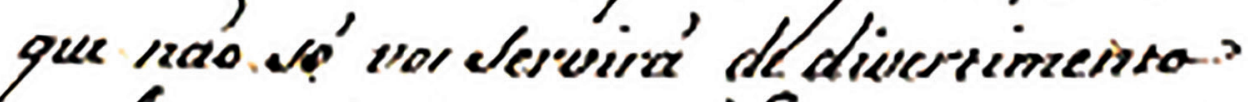
pele novidade; mas raobem umime de des rafogo, alivio.

Lo acabado de encraserds emel Lase.

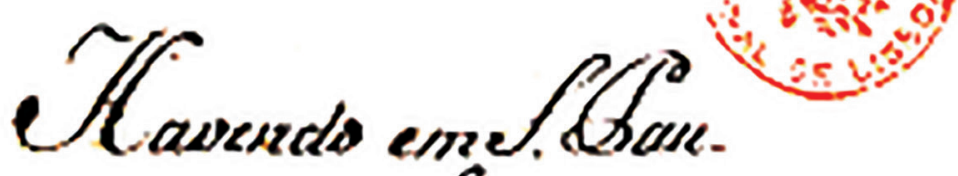

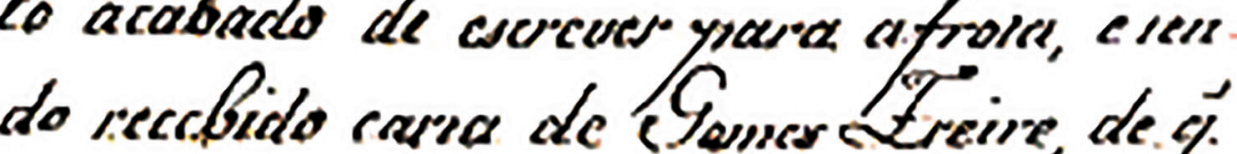

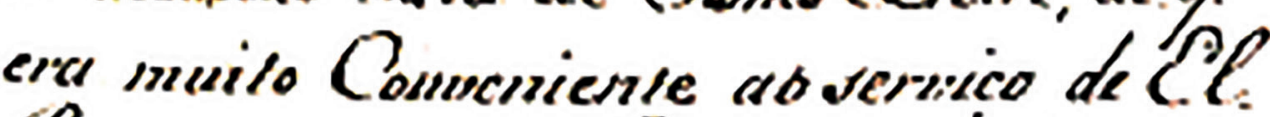

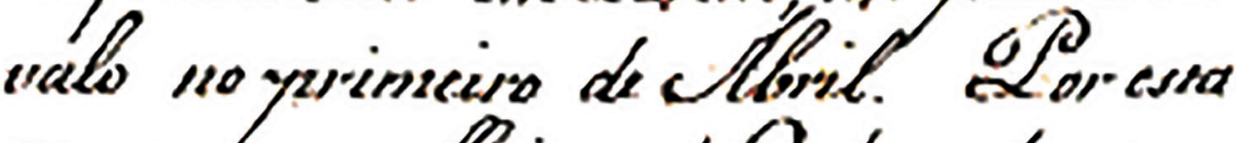

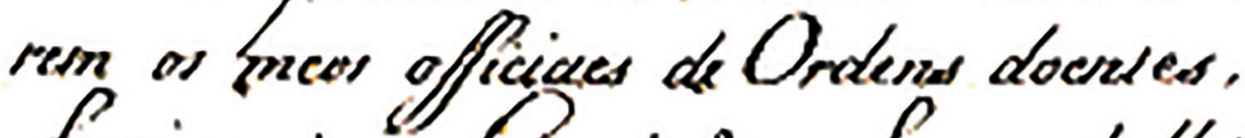

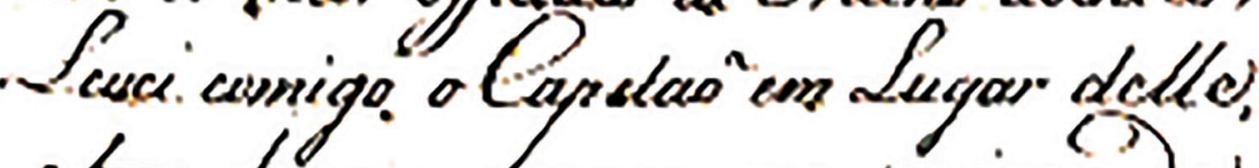

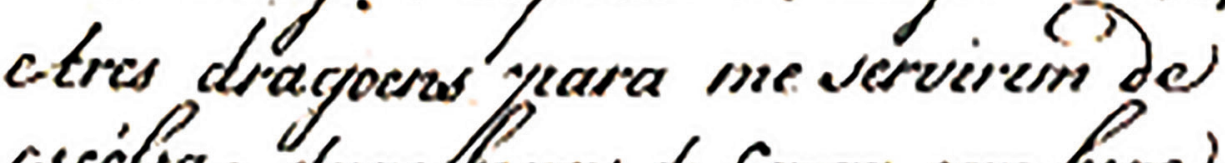
scilin: Lusus besras de curga combern your- 


\title{
Fólio 2r [01.04.1750] (Fig. 6)
}

\begin{abstract}
Meu Primo 7 e Senhor. Quanta/ terra, e quanta agoa tenho passado de pois/ que vos escrevi! Rios taõ caudalozos, mat-/tos taõ espessos, e campos taõ dilatados, que/ fazem admiraçaõ principalmente a quem/vem de hũa terra taõ apertada, como o/ nosso Reino. Desejara Lembrar-me, e saber ordenar tudo, quanto passei, e vi, o/ que naõ só vos Servirá de divertimento/ pela novidade; mas taõbem a mim de de-/ zafogo, e alivio.

Havendo em S. Pau-/lo acabado de escrever para a frota, e ten-/do recebido carta de Gomes Freire, de q.'/ era muito Conveniente ao serviço de El/ Rey vermo-nos em Parati, me púz a ca-/minho no primeiro de Abril. Por esta-/rem os meos officiaes de Ordens doentes,/levei comigo o Capitaõ em lugar delle,/e tres dragoens para me servirem de/ escólta: duas bestas de carga com bem pou-/
\end{abstract}

pou-

7 Antônio Rolim de Moura era primo do rei de Portugal D. João V.

8 António Gomes Freire de Andrade (Juromenha, concelho de Alandroal, distrito de Évora, Portugal, 1685 - Rio de Janeiro, 1 de janeiro de 1763) foi um nobre militar e administrador colonial português. Foi feito primeiro conde de Bobadela por carta de 20 de dezembro de 1758.

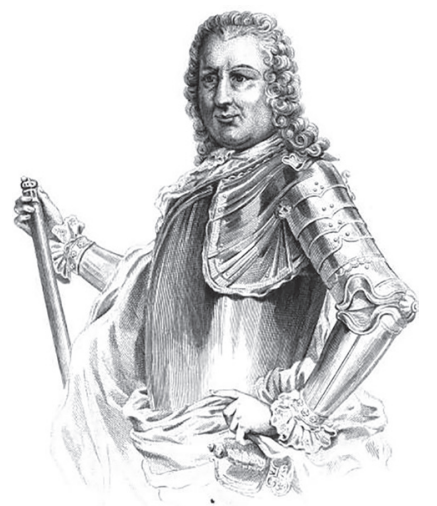

Antônio Gomes Freire de Andrade, Conde de Bobadela.

Filho de Bernardino Freire de Andrade e de D. Joana Vicência de Meneses, foi moço fidalgo com exercício, acrescentado a fidalgo escudeiro, do Conselho do rei D. João V de Portugal e do rei D. José I de Portugal. Foi governador e capitão-general do Rio de Janeiro durante trinta anos, entre 1733 e 1763. Estudou no Colégio das Artes da Universidade de Coimbra, período em que assentou praça, progredindo na carreira militar durante a Guerra de Sucessão da Espanha. Provido de comando superior, terminada a campanha, teve 0 encargo de comissões importantes e, em 1733 foi nomeado Capitão-general da Capitania do Rio de Janeiro, tomando posse do cargo em 26 de julho. Comissário e primeiro plenipotenciário de Portugal nas conferências sobre os limites da fronteira ou parte meridional do Estado do Brasil com as colônias espanholas da América do Sul, que alcançava desde Castilhos Grandes até a foz do rio Jauru. General da Divisão portuguesa e depois comandante em chefe das tropas auxiliares de Espanha e Portugal que foram ao Rio Grande do Sul e ao Uruguai, Buenos Aires e Colônia do Sacramento, sujeitar os índios rebeldes instigados contra o domínio português e espanhol, pelo predomínio dos jesuítas, apoiados na influência do governo inglês, que desde 1740 perscrutava a maneira de assentar o domínio da Inglaterra no rio da Prata, dominar toda a América do Sul e acabar para Portugal 0 domínio do Estado do Brasil. Em 1735 recebeu 0 encargo de administrar também as Minas Gerais, e em 1748, havendo aumentado a população de Goiás, Cuiabá e Mato Grosso, incumbido de administrar as duas novas capitanias que se fundaram. Assim, enviado ao Brasil para ser governador da Capitania do Rio de Janeiro, acumulando sob seu comando os territórios de Minas Gerais, São Paulo, Mato Grosso e sul do Brasil. No Rio de Janeiro, junto ao sargento-mor José Fernandes Pinto Alpoim, realizou obras como o Aqueduto da Carioca, a Casa dos Governadores terminada em 1743, e o chafariz ou fonte pública da praça do Carmo. Incentivou também a construção de importantes obras religiosas, como o Convento de Santa Teresa e 0 Convento da Ajuda (demolido). Permitiu a abertura da primeira tipografia da colônia, criada no Rio de Janeiro em 1747 por Antônio Isidoro da Fonseca, mas que teve de ser fechada por ordem do governo português. Incentivou a cultura também pela criação de academias de intelectuais: a Academia dos Felizes (1736) e a Academia dos Seletos (1752), ainda que nenhuma teve vida longa. Depois da atuação notável como governador, uma vez denunciadas ao governador em 1744 pelo guarda-mor J.R. Froes as riquezas do distrito diamantino de Paracatu, cuidou logo de explorar os terrenos. Agiu para o aproveitamento das minas de Paracatu, recém descobertas, esforçando-se para tentar acabar com a falta de controle da circulação do ouro e a desorganização da coleta dos quintos. Reprimiu o contrabando, articulado a partir do Rio, estabeleceu um sistema de taxas sobre 0 ouro de Minas, determinou a imposição de um contrato sobre os diamantes do Tijuco, distrito que Portugal mantinha rigorosamente fechado, supervisionou a renovação urbana do Ribeirão do Carmo rebatizada Cidade Mariana em homenagem à Rainha D. Maria Ana de Áustria. Atuou intensamente em favor da cultura e instrução na colônia. Em decorrência do Tratado de Madrid (1750), o governador deslocou-se em 1752 junto com Fernandes Alpoim à região sul para delimitar as fronteiras com as colônias espanholas. Comandou as tropas luso-espanholas que venceram os índios guaranis durante a Guerra Guaranítica (1754-1756), em que lutou contra o líder guarani Sepé Tiaraju. Ao mesmo tempo que prestava atenção aos interesses materiais do país sujeito a seu domínio, atendia à instrução e ao amor pela literatura, empregando os meios possíveis para o seu desenvolvimento. A ele se deve o estabelecimento da oficina tipográfica do Rio, de que foi proprietário Antônio Isidoro da Fonseca. A tipografia durou pouco, porque a iniciativa desagradou ao governo da metrópole, temeroso da demasiada ilustração dos colonos, que censurou muito que o capitão general concedesse autorização para que se fundasse e ainda não satisfeito com a censura, ordenou que se fechasse. Os primeiros escritos impressos foram: "Relação da entrada que fez o exmo e revmo senhor Dom Frei Antônio do Desterro Malheiros, bispo do Rio de Janeiro, em $1 .{ }^{\circ}$ do ano de 1747, havendo sido seis anos bispo de Angola, d'onde por nomeação de Sua Majestade e bula pontificia foi promovido para esta diocese", composta pelo doutor Luís Antônio Rousado da Cunha, juiz de fora, etc.'; 'Em aplauso do exmo e revmo sr D. Frei Antônio do Desterro Malheiros, dignissimo bispo d'esta cidade”, romance heróico in folio"; "Coleção de 11 epigramas e 1 soneto, aqueles em latim, êste em português, sobre idêntico assunto". Tais composições não têm grande valor, porém são muito apreciadas no Brasil por serem os primeiros trabalhos tipográficos no Rio de Janeiro. Foi ainda durante seu governo que se fundaram duas academias, a dos Felizes e a dos Seletos. Auxiliava os que se dedicavam ao estudo e entre os muitos que mandou educar no seminário de São José esteve José Baślio da Gama que, depois de concluir sua educação à Europa, reconhecido à sua memória, escreveu o poema Uruguai ou 0 Uraguai, cujo herói é Gomes Freire, publicado em Lisboa em 1769. Como militar se distinguiu na guerra do Rio Grande do Sul contra os índios, de 1750 em diante, derrotando em menos de seis meses os inimigos que os jesuítas dirigiam ocultamente. Foi responsável por grandes contribuições para a tecnologia militar, destacando a criação, em 1762, da "Casa do Trem da Província do Rio de Janeiro", local destinado ao abrigo e reparo do equipamento de Artilharia do Exército Colonial. A Casa do Trem é o marco de origem das atividades da indústria bélica no Brasil Colônia, além de ser a precursora dos atuais Arsenais de Guerra do Exército Brasileiro. Depois do Pacto de Família, Portugal declarou guerra à Espanha, de que resultou D. Pedro de Cevallos tomar a cidade do Sacramento, que arrasou e à qual nunca chegaram socorros do Rio de Janeiro. Diz-se que este fato lhe causou tão poderosa impressão que recebeu a notícia em dezembro de 1762 e adoeceu gravemente, morrendo em 1 de janeiro seguinte. Está sepultado na capela do convento de Santa Teresa, no Rio de Janeiro. Deixou em testamento um valiosíssimo morgado em favor do irmão, José António Freire de Andrade, pois não se casou nem teve filhos. Graças a seus serviços à Coroa, D. José I (rei de 1750 a 1777) concedeu-Ihe em 1758 o título de conde de Bobadela. 0 título foi herdado por seu irmão, José Antonio Freire de Andrade, que 0 transmitiu a seus descendentes. 0 $3 .{ }^{\circ}$ conde de Bobadela foi Gomes Freire de Andrade e $04 .^{\circ}$ e último titular D. Nuno Manuel (28|9\1828). No testamento, confirmou a instituição de morgado que por escritura de 13 de março de 1761 fizera nas Notas do Tabelião do Rio, Salvador Antônio Velasco, em favor do irmão José Antônio, em bens no valor de 88:066\$400, que deveria ser ainda aumentado por ocasião de seu falecimento, pelo modo que determinara, e foi aprovado e confirmado por provisão do Desembargo do Paço em 21 de julho de 1778. Por proposta do senado da câmara do Rio, fora ordenado em aviso de 13 de agosto de 1760 que o retrato do conde fôsse colocado na sala do referido senado. (https://pt.wikipedia.org/wiki/Gomes_Freire_de_Andrade,_1. $0^{\circ}$ Conde_de_Bobadela). 


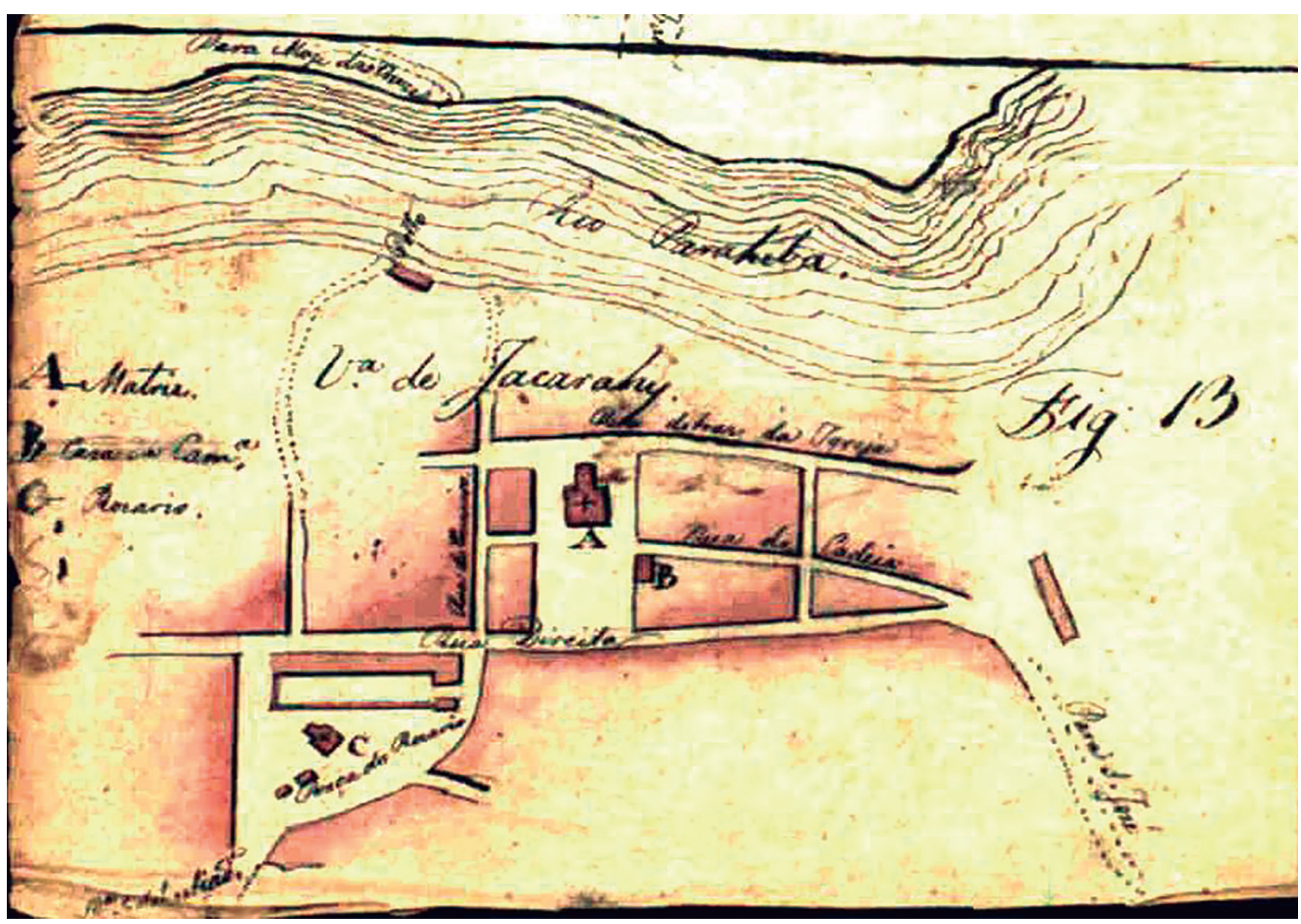

Figura 7. Vila de Jacareí e antigo leito do rio Paraíba do Sul (Arnauld Julien Pallière, 1821; Coleção Yan de Almeida Prado, Instituto de Estudos Brasileiros, Universidade de São Paulo).

Fólio 2v

pouco provimento, para poderem acompa-/nhar-me dois Criados; e alguns pretos./

Este pequeno trém, custou bastante a pôr/prompto, sendo-me necessario comprar a/maior parte dos Cavalos pelos naõ haver na-/quella terra de aluguer. Acompanhou-/me taõbem o Ouvidor de S. Paulo; belo/ para similhantes funçoens; por que naõ a-/tura sol, nem está na sua maõ o madrugar.

Sahimos em fim da Cidade já tar-/de por amor delle, e para mais ajuda erra-/mos o caminho, por cuja cauza andamos de/noute hũas poucas de horas, por estrada/que ainda de dia se passa com dificuldade,/ cheia de más pontes, de Ribeiros, e de atolei-/roa terriveis. Estas dificudades me emba-/raçaraõ chegar ao Sitio; que assim chamaõ/ cá aos Cazaes, aonde me esperavaõ; e/ fiquei noutro, em que naõ havia nada/ que comer para a gente, nem para os $\mathrm{Ca}-/$

valos

\section{Fólio $3 r$ [02.04.1750]}

Cavalos. No dia seguinte fui jan-/tar a Mogi [Mogi das Cruzes] marchando hum grande pe-/daço a otravéz de vargeas larguissimas, mas/ inuteis pela opinião, em que está a gente/ da America de que só em rossas se pode se-/mear, ou plantar: a Villa hé pequena, co-/mo todas as que vi na Comarca de S. Pau-/lo; por que a maior parte dos moradores as-/sistem nos seus sitios, aonde lhe vai o tempo/ em cachimbar, o embalançarse na rede em/Camiza, e cilouras; seu vestido ordinario./ e mandando os Seus Carejós, adquiridos/pelo Sertaõ ${ }^{9}$ com grandes trabalhos, e naõ/menos offenças de Deos. Daqui fui dor-/

9 Os portugueses utilizavam o termo sertão desde o século XIV para referirem-se a lugares do reino que fossem distantes de Lisboa. No século XV, passaram a chamar de sertão também aquelas localidades vastas, interioranas, pouco conhecidas e habitadas, situadas em suas colônias. É um vocábulo antigo, trazido ao Brasil pelos portugueses e que continuou a ser utilizado pelos viajantes e cronistas na descrição do cenário e imaginário colonial. Analogamente, a palavra sertão está nas correspondências oficiais entre os administradores lusos radicados na Colônia, embora, aqui incluísse um dado novo: aludia-se a lugares onde uma estruturação político-administrativa já havia sido estabelecida, haja vista a presença de núcleos de povoamento, de vilas e de aparatos burocráticos, podendo ser no mais interior da Colônia (Amado, 1995; Canova, 2011). 
mir a hũa fazenda dos Pes do Carmo, e no/ outro dia a Jacaray [Jacareí] (Fig. 7), que taõbem falando/ mal, hé Villa; parece-me terá meia duzia/ de cazas; taõ pobre que a Camera me es-/perou de Capote. Seis Legoas antes de/chegar a ella todo o caminho hé por morros/muito altos, muito a pique, e de hũa quali-

dade

\section{Fólio 3v [05-06.04.1750]}

qualidade de barro, como o Sabaõ, quando cho-/ve, o que aconteceu nesta occaziaõ; por cuja/ cauza passamos com bastante risco de que-/brar as pernas; escorregando a cada passo/os Cavalos; mas andaõ taõ destros, que pa-/rece incrivel as partes por onde se seguraõ./ Eu naõ hiria a pé por ellas, sem cahir hũa/ quantidade de vezes. Ao Sahir daquella/Villa há hum pedaço de caminho, que parece/ rua de quinta, muito direito, Largo, e cheio de/ boa sombra. Depois se dá em campos de per-/dizes, em que com effeito vi Levantar alguas $\mathrm{sem} / \mathrm{me}$ afastar da estrada. Nessa noite, que foi/ a quarta, dormi bastantemente mal acomo-/dado em sitio, que está dentro de hum Ca-/paõ de matto de quatro Legoas de Comprido./ Na seguinte fiquei na Villa de Taubaté, a/ melhor, que vi naquelle caminho, bem assentada com boas ruas, largas, e compridas ale-/gre; e os seus moradores mais civilizados.

No dia $6 .^{\circ}$ jantei em/

Pida/l

Fólio 4r [07.04.1750]

Pidáminhangaba [Pindamonhangaba], Villa quaze igual á de Ja-/caray; nella Comi paõ do mesmo trigo da ter-/ra muito semilhante ao paõ francês, no/gosto, no feitio, eno amassado. No dia se-/guinte ao jantar cheguei a Goratinguitã [Guaratinguetá] Ha-/vendo na noute antecedente ficado em sitio/ bom á vista dos mais; porem o caminho, que/ nelle me conduzio, héra cheio de más pontes,/ atoleiros, e caldeiroens, que saõ hũas covas,/ que os Cavalos fazem, com a continuação/de andar, as quaes, quando chove se en-/chem de agoa e lama, ficando entre cova/ e cova, como hũa parede de barro duro,/ de sorte, que hé necessario, que os Cavalos/vaõ por estes Lugares muito socegados, pon-/do os péz dentro nas mesmas covas; por/que se assim naõ o fazem, infalivelmente/Cáem com o grande risco de quebrar as per-/nas ao Cavaleiro. Este taõ bom caminho/passei com tanto escuro, que nos não via-/mos huns aos outros.

A Villa/l

\section{Fólio 4v}

A Villa de Goratinguitá, em que fiquei na-/quelle dia por ser necessario mandar diante/ avizar os Sitios por onde havia passar, hé/já mais Rica, do que as outras por ser para-/gem para as Minas daquelles, que vem bus-/car a estrada do Paratî; pela qual me segu-/raraõ andavaõ mil, e trezentos Cavaleiros con-/duzindo cargas. Aqui deichei o Caminho/da esquerda, que vai á Serra da Manti-/quera (Figs. 8 e 9), e dahiás Minas, e tomando a direita/ fui dormir ao Sitio da Paratinga [São Luís do Paraitinga], marchã-/do todo o dia môrro abaixo, môrro assima,/ taõ altos e empinados, que quaze todos os ca-/valos agoaraõ, até os que hiaõ á maõ, e foi/precizo Sangralos, o que me causou a demo-/ra de dous dias, ao que me sugeitei por saber/ahi, que Gomes Freire naõ podia sahir do/ Ryo de Janeiro no dia, que me tinha aviza-/do. Occupei esse tempo em andar pelo ma-/to atirando aos Papagaios, e aos Tucanos,/ de que havia boa quantidade. Da/

qui//

\section{Fólio $5 r$}

Daqui a Paratígastei dois dias: no primei-/ro fui ao Sitio da Apariçaõ ${ }^{10}$, em que se experi-/menta o mesmo frio do Reino, o Segundo me/Levou toda a Serra de Paratí(Fig. 10), que na opinião/Cõmum hé a pior, que

10 Município de Cunha, SP. Em 1597, uma expedição portuguesa comandada por Martim Correia de Sá saiu do Rio de Janeiro, desembarcou em Paraty e passou pela região de Cunha através da Trilha dos Guaianás visando a combater os tamoios, que estavam aliados aos franceses contra os portugueses. Desde o final do século XVII, a região já era conhecida como "Boca do Sertão", por ser um ponto onde se subia a serra em direção às Minas Gerais. Em 1730, viajantes se fixaram na região e fundaram um povoado. No povoado, a família portuguesa Falcão ergueu a capela da Sagrada Família. Por este motivo, o povoado passou a ser conhecido como "freguesia do Falcão". No início do século XVIII foi erguida, entre a freguesia do Falcão e Paraty, a Barreira do Taboão, que era um posto destinado a controlar o fluxo de ouro procedente de Minas Gerais. 0 povoado foi elevado a vila em 3 de setembro de 1785 pelo então governador da Capitania de São Paulo, Francisco da Cunha e Meneses, com o nome de Nossa Senhora da Conceição de Cunha, em homenagem ao político. No século XIX, as antigas trilhas foram calçadas e ampliadas visando a transportar a grande riqueza da época: 0 café. Foi elevada a município em 1858 com a emancipação de Guaratinguetá, já com a denominação atual. 


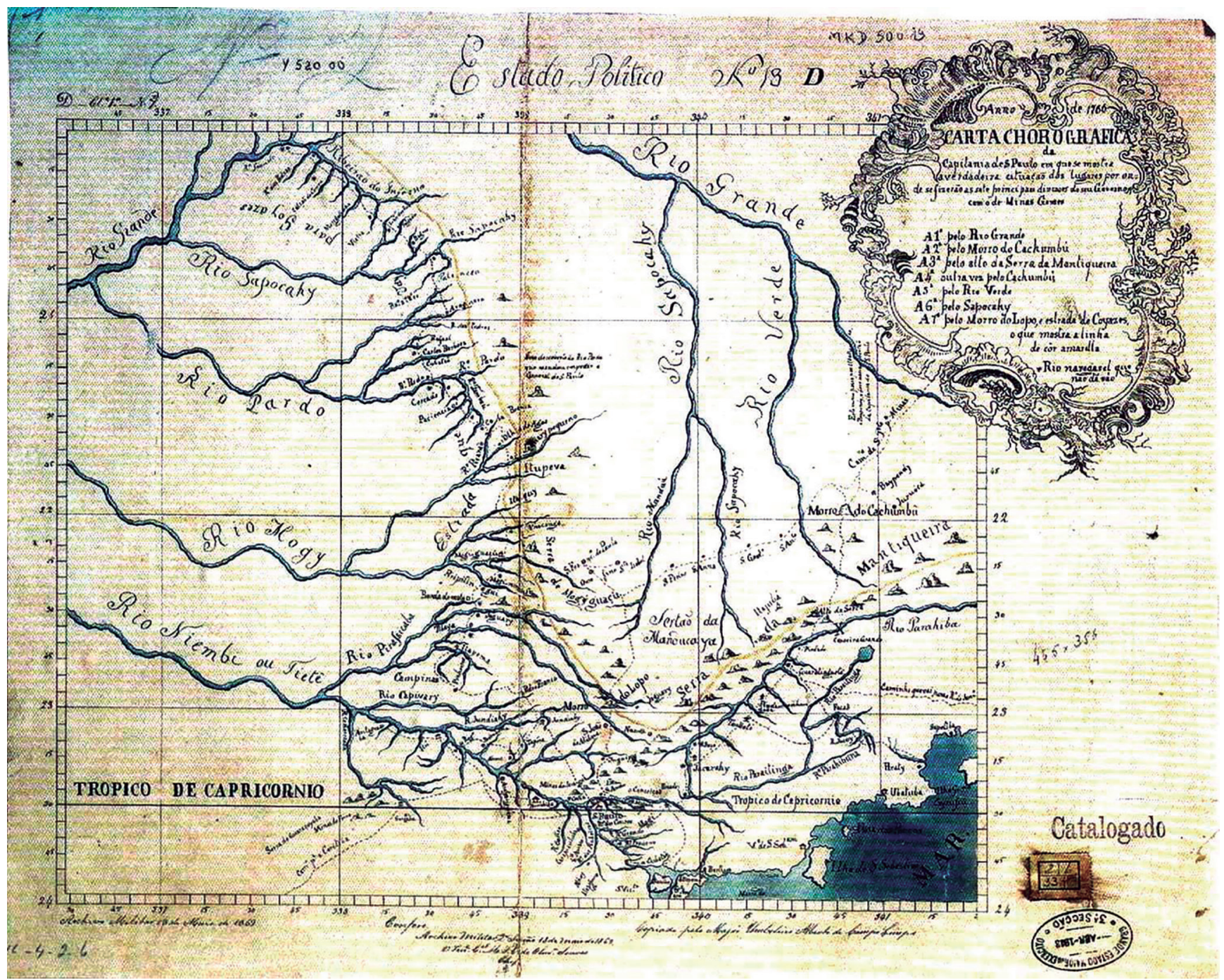

Figura 8. Mapa de São Paulo (1776).

se conhece. A estra-/da em partes hé taõ apertada aberta em Ro-/cha, que me hera necessario Levantar os péz/ até os pôr na garupa do Cavalo, e nem com/ tudo isso escapei de dar muito boas topadas./ Tanto a pique, que oito dias me ficarão doen-/do as Cadeiras de me indireitar. O chaõ es-/tava calçado, ou alastrado de pedras Soltas, / e deziguaes com muitos sabros, e barrocas; e a-/onde este faltava, era atoleiro grande, e cal-/deiroens muito fundos. Continuamente/ chove; e faz em certos tempos frios taõ ex-/traordinarios, que tem já morto alguns/ passageiros, porque como ella naõ hé ca-/paz de se andar de noite, aquelles a quem/ o dia falta antes de a vencer, ficaõ expóstos a/ este perigo, pois naõ podem reparar o frio/

com//

\section{Fólio 5v}

com o fogo por estar sempre o mato por mo-/lhado incapaz disso. Alem disto tem duas/passagens de rio bastantemente más.

Na Villa me receberão, como/ se fosse o proprio General; a passagem, que/ por ella se faz para as Minas, e a quan-/tidade de agoardente de cana, que ali se/fabrica, Ihe daõ algũa opulência. Fica qua-/ze Norte Sul com a llha Grande, e dis-/tante della dez Legoas, cituada á borda de/ hũa grande Bahia, que ali forma o mar/com fundo capaz de ancorarem naos de/guerra; taõ abrigada, por cauza das muitas/ilhas, que a amparaõ da banda do mar,/ que em Canoas de pá se vae por entre ella/ até a Supetiva [Sepetiba], que saõ vinte Legoas, el dahi ao Ryo de Janeiro: quatorze, Cami-/nho sumamente frequentado pelas muitas/Cargas, que por ali passaõ para as Mi-/nas.

O tempo, que Gomes Freire tardou/ 


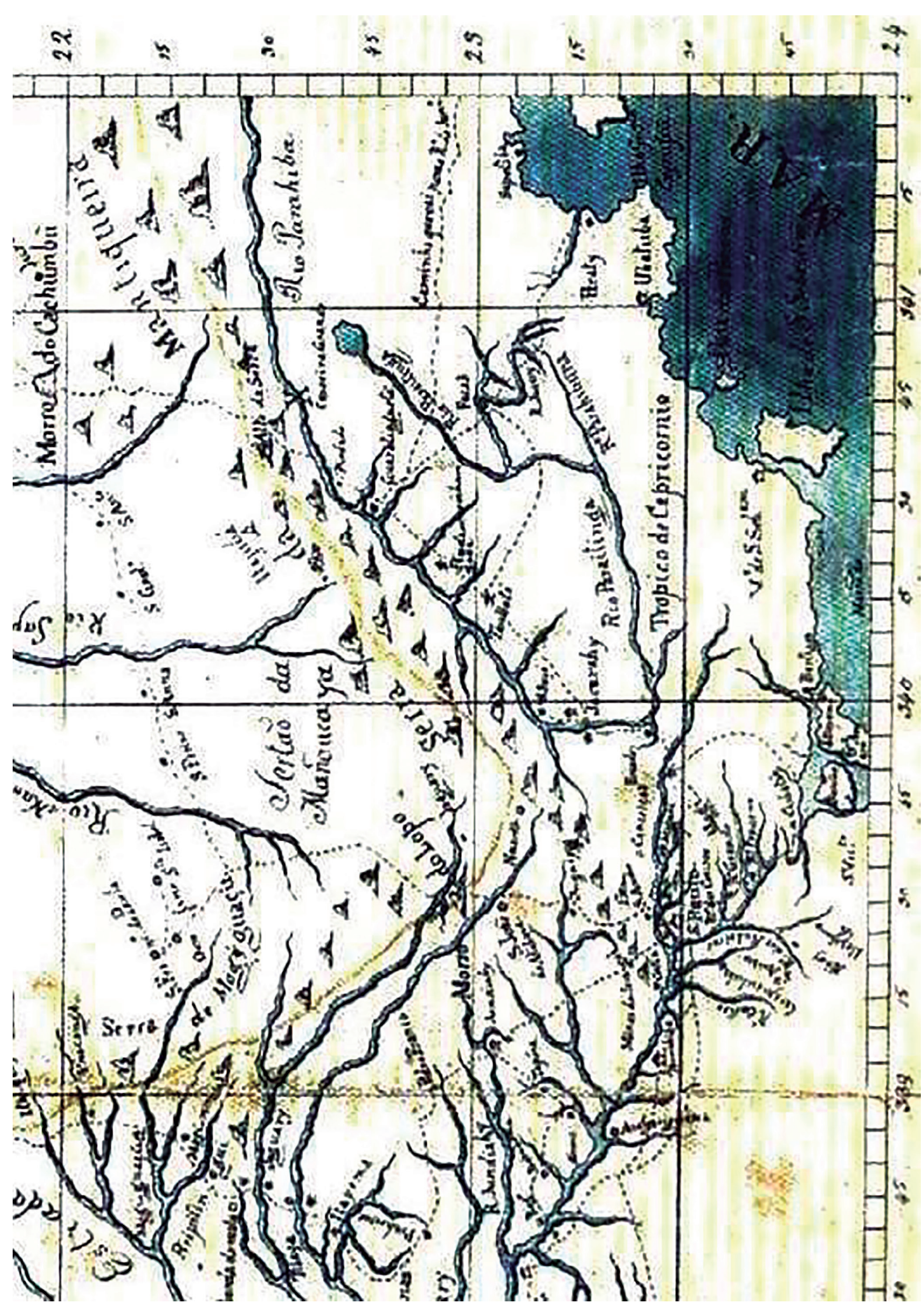

Figura 9. Detalhe do mapa anterior, mostrando a Serra da Mantiqueira e, ao sul dela, as cidades por onde passou o Conde de Azambuja de São Paulo a Parati. 


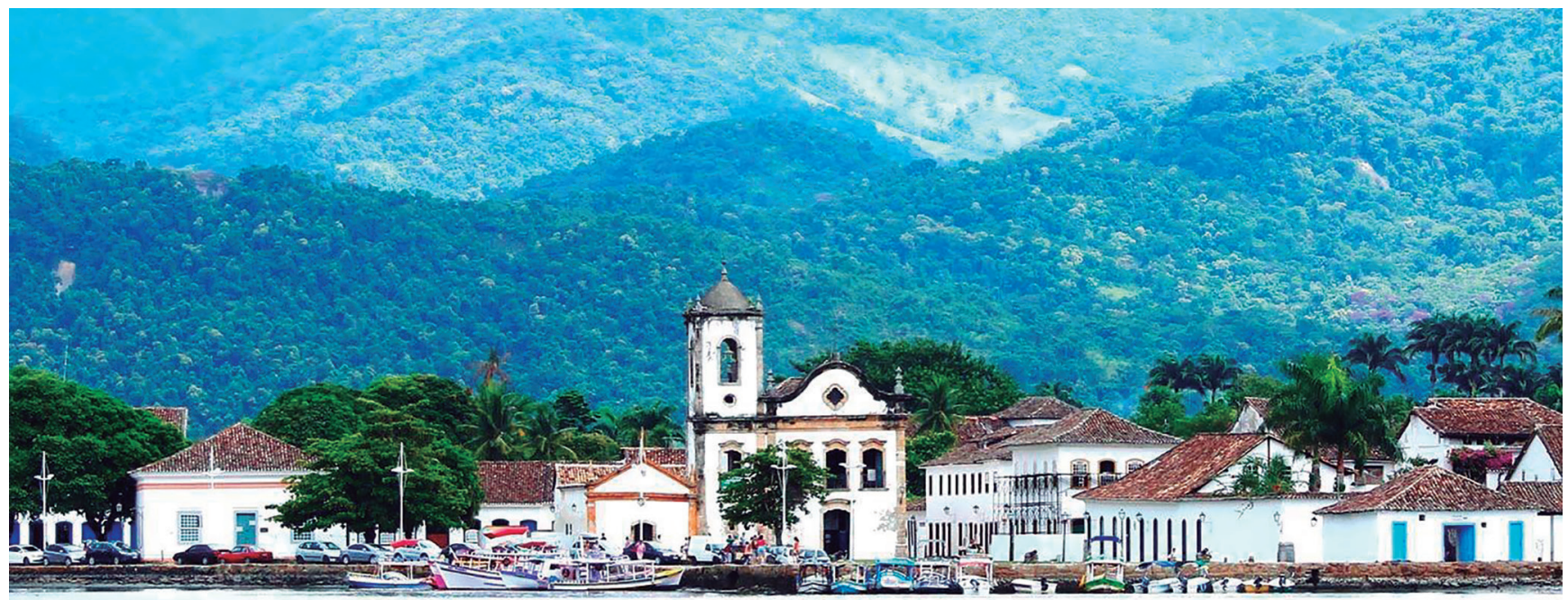

Figura 10. Vista atual de Parati, RJ.

\section{Fólio 6r}

por cauza da Frota me servio de divertimento/ e passear por esta baýa em hũa Canoa, que/ sem embargo de me segurarem ser a menor/ de tres, que se haviaõ tirado do mesmo pao,/Levava Seis remos de voga; e na poupa aco-/modava seis, e sette pessoas; finalmente se/ naõ diferençava de hum escaler de seis re-/mos. Gomes Freire quando chegou me/ fez muita festa, e agazalho. Achei-lhe a mes-/ma viveza, desembaraço, e a muita despozi-/cão, com que sempre o conheci. Todas as/menhaãs me foi buscar a Caza, aonde conferiamos até ás dez horas; hiamos á mis-/sa, e dahi para sua Caza, aonde jantei,/e Ceei sempre com os seus officiaes, e as pesso-/as, que havião hido comigo; o que me naõ/ hera possivel na minha, tendo me sido/ precizo vir àquella jornada taõ escuteiro,/Como já disse. Naõ se lhe pode duvidar a/ Capacidade, nem o Zelo, com que Serve a/ El Rey, e com grande dezinterece e Lim-/

peza/l

\section{Fólio 6v [01.05.1750]}

Limpeza de mãos, e se elle tiver algũa cou-/za, em que a consciencia o accuze, parece-me/ será mais da preça por puchar demaziado/ para a Fazenda Real, que por deichar/ perder couza algũa della. Hé activo, e/ prudente, sofredor, quando hé necessario;/ naõ obra couza algũa sem tençaõ: hé po-/lido, e attenciozo com os seus subditos. Final-/mente, tenho-o em conta de bom Governador.

No primeiro de Maio/ me puz a cavalo, e a onze cheguei a S. Pau-/lo, cuja jornada fiz com grande descanço, ha-/vendo Largado a Companhia do Ouvidor/ por ficar Logo em Goratinguita começando a/ Correiçaõ. Ao amanhecer me punha em mar-/cha e ao meio dia té a hua hora me arrancha-/va, com o que me livrava do maior Calor,/ que nestas terras começa do meio dia, el dura quaze até o pôr do Sol. Porem/ tive Lugar de marchar assim, por que ha-/

via//

\section{Fólio 7r}

havia mandado um proprio adiante por to-/das as Villas, e sitios com avizo do dia, em que a/ elles chegava para terem milho prompto, e/ capim para os cavalos; pois sem esta pre-/venção hé precizo Largalos ao pasto, de onde/ se naõ podem tirar sem amanhecer, e ás ve-/zes se espera por elles a té muito tarde, e ou-/ tras naõ aparecem de todo, e este hé o maior dis-/comodo, e ambaraço, que tem as jornadas por/ estas terras, e as dificulta extraordinariamen-/te, fazendo-se com grande commitiva.

$\mathrm{Em} / \mathrm{S}$. Paulo me demorei dez dias, que foraõ pre-/cizos para dispor algũas couzas perten-/centes á viagem dos Ryos. Parti para/ Araritaguaba11, aonde cheguei em dois di-/as e meio. O Juiz de Fóra

11 Atual Porto Feliz, na margem esquerda do rio Tietê. A Vila de Porto Feliz foi criada no reinado de Dona Maria I, rainha de Portugal. 0 documento de criação foi assinado pelo governador da Capitania de São Paulo, António Manuel de Melo e Castro de Mendonça, no dia 13 de outubro de 1797.0 povoado às margens do rio Tietê, chamado anteriormente Freguesia de Araritaguaba, pertencera até então ao termo da vila de Itu. 


\begin{abstract}
Theotonio da/Silva Gusmaõ ${ }^{12}$ tinha muito adiantado o a-/presto das Canoas; porem como dahi nun-/ca se tinha feito hũa semilhante expe-/diçaõ, e a experiencia hé que foi mostran-/
\end{abstract}

\title{
Fólio 7v
}

mostrando a necessidade de muitas couzas, as/ quaes pelas naõ haver ali se mandarão vir/ do Ryo de Janeiro, Foi necessario esperar por/ ellas, e taõbem dar Lugar a que crescece o mi-/lho, e feijão e se fizessem as Farinhas, e touci-/nhos; hũa e outra couza me demorou a-/té a Agosto.

Grandes Foraõ as contradiçoens,/ que desde o Ryo de Janeiro experimentei a/ fazer a jornada por esta parte, e era tal sem-/pre o correr, com que todos falavaõ nella tan-/to naquella Cidade, como em Santos, em S./Paulo, e ainda na Araritaguaba, que receei/ muito me fugissem os Soldados todos por es-/ ta Cauza, o que foi hũa das que me mo-/veraõ a ella, e depois de tomada esta re-/zoluçaõ, sempre em publico me mostrei/firme neste propozito, para que elles se/ animassem.

Tanto por estes receios, co-/mo por outros muitos embaraços, que se-/

12 Teotônio da Silva Gusmão. Paulista nativo de Santos e formado em Coimbra, era sobrinho do embaixador Alexandre de Gusmão. Sabe-se que, no ano de 1735, Teotonio da Silva Gusmão era fiscal do ouro em Goiás, onde atuou de dezembro do mesmo ano até junho de 1737. Nesse período "foi mandado pelo mesmo governador [Conde de Sarzedas] a criar a Intendência das minas do Tocantins, cujo emprego serviu até setembro de 1738". Após um período de dez anos, em que provavelmente tenha advogado no reino, Teotônio da Silva Gusmão, em 1747, chegou à Vila de Itu para assumir o posto de juiz de fora. Em carta de 1748 chegou uma ordem do Conselho Ultramarino para que o cargo de juiz de fora fosse extinto na Vila de Itu e para que se criasse um na Vila de Guaratinguetá, com alçada nas vilas vizinhas de Pindamonhangaba e Taubaté. Ordenou-se também que o juiz de fora que então estivesse atuando em Itu - no caso, Teotônio da Silva Gusmão -, realizasse as eleições para juiz ordinário e que passasse logo para a vila do Mato Grosso a servir de juiz de fora com a mesma carta e provisões que foi para aquela vila [de Itu], e vença o mesmo ordenado que tem na Provedoria de Santos e na nova vila com as mesmas propinas e aposentadoria que tinha na Itu com a promessa de atender aos seus acrescentamentos no serviço que lhe fizer no estabelecimento da nova vila, e mandando-Ihe dar por uma vez 500 mil réis de ajuda de custo para se transportar à Vila do Cuiabá e dali à do Mato Grosso, que se pagará na provedoria das mesmas minas. Enquanto esperava pelo período das monções, organizou a expedição que acompanharia o governador Antônio Rolim de Moura para a capitania de Mato Grosso. De acordo com o governador, além de preparar a viagem, responsabilizou-se ainda "por sua conta acompanhar as canoas que depois de mim saíram daquele porto [Araritaguaba] com cargas de munições e fardos pertencentes à Real Fazenda". Na Vila do Cuiabá, a despeito de estar doente, realizou "várias diligências do serviço de Vossa Majestade", e, a mando do governador, foi designado a escolher o sítio mais oportuno para a nova vila que o rei havia mandado erigir para cabeça de governo. Após chegar ao termo do Mato Grosso continuou a procura pelo local adequado descendo o Rio Guaporé, "0 que nenhum sertanista até aquele tempo tinha feito, pelo temor das cachoeiras e outros perigos" naturais dos caminhos fluviais. Os aventureiros tinham como parâmetro de comparação o caminho de Araritaguaba, no porto de Itu, até o porto geral da Vila de Cuiabá, que era repleto de perigos naturais e humanos e imaginavam que o caminho novo conteria as mesmas dificuldades. Até então apenas um criminoso havia feito o percurso do Rio Guaporé e o resultado dessa viagem era desconhecido. Teotônio Gusmão realizou a viagem por rio e, para sua surpresa, encontrou apenas uma cachoeira no inicio da viagem, sem que houvesse maiores dificuldades posteriores. Encontrou "0 melhor caminho para comunicação com aquelas minas [distrito do Mato Grosso] com a do Cuiabá, e tendo também achado um sítio muito próprio para a fundação da nova vila que a criou o governador (...)". Segundo afirmou em um requerimento ao rei, datado de 20 de maio de 1757, tendo obtido autorização para ir ao Reino, resolvera gastar a ajuda de custo que recebera para a viagem, concretamente 2 mil cruzados, bem como uma boa parte de seu próprio pecúlio, com o estabelecimento de uma nova povoação que assegurasse a posse portuguesa do rio Madeira. Representava ainda que, com aprovação do governador de Mato Grosso, passara à cachoeira do Salto Grande do rio Madeira, a penúltima, rio abaixo, paragem havida por mais cômoda aos viandantes que navegavam com negócio entre as duas capitanias, conduzindo "a sua Custa mais de sessenta pessoas, brancos, e mulatos forros, solteiros, e cazados, pretos e índios de serviço". Assim, por se ter lançado a tarefa tão útil ao Real Serviço, qual fosse a criação dessa povoação chamada Nossa Senhora da Boa Viagem, da maior importância para consolidar a rota fluvial entre Vila Bela e Belém, para o que "se sacrificou voluntario a viver em hú dezerto, athe alli innhabitado, e só visto de passagem, p. a fazer exemplo a outros", requeria o ordenado de 4 mil réis anuais com o título e lugar de superintendente geral das cachoeiras dos rios Madeira e Mamoré, a beca e passe em um dos lugares da Relação do Porto, e a mercê de três hábitos de Cristo para dois filhos seus e para quem casar com sua filha. Desprovido de recursos e impaciente com a resposta do poder central, remeteu uma carta mais incisiva ao governador do Pará em 1758, que referiu o caso ao de Mato Grosso e, sem entrar no teor do papel, disse que preferira"guardalo na m. ${ }^{\text {` }}$ gaveta". Entretanto, Teotônio da Silva Gusmão fora nomeado para ouvidor das minas de Cuiabá, o que não agradou a Francisco Xavier de Mendonça Furtado que, em carta a Rolim de Moura, manifestava

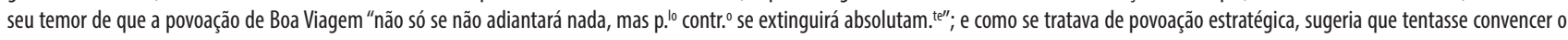
ministro de que ele podia "ser despachado à sua satisfação, sem sair daquelle importante lugar". De fato, Teotônio da Silva Gusmão abdicou do cargo de ouvidor do Cuiabá, provavelmente na expectativa de que a Coroa concederia as mercês mais interessantes que requisitara. Em 1761, a povoação de Boa Viagem foi abandonada, e Teotônio da Silva Gusmãoapareceu no Pará reclamando seus vencimentos. Morreu três anos depois (Almeida, 2014; Carvalho, 2014).

Próximo a cidade de Porto Velho, capital do estado de Rondônia, no rio Madeira, até o final de 2011, podíamos encontrar a cachoeira do Teotônio, que foi submersa pelo reservatório da Usina Hidrelétrica Santo Antônio.

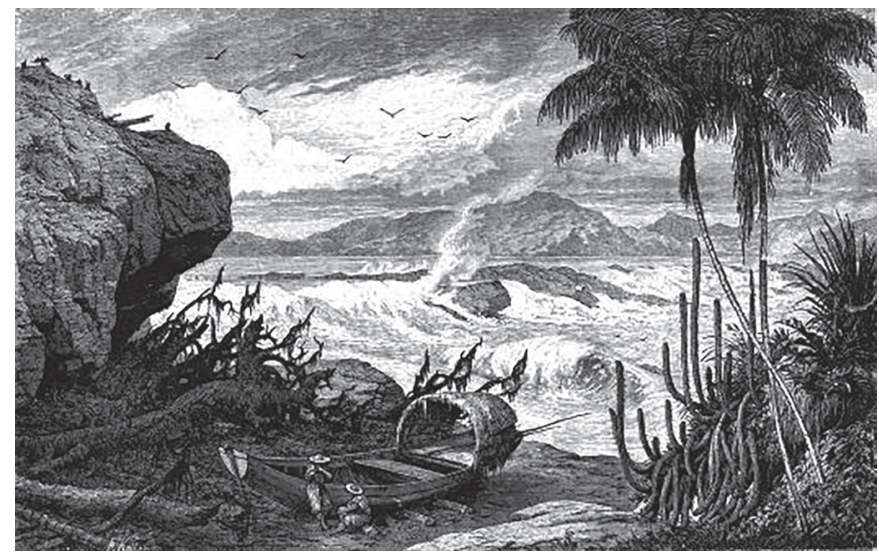

Cachoeira do Teotônio (Keller-Leuzinger, 1874, figura entre as pp. 46 e 47). 
Fólio 8r [05.08.1750]

seriaõ impossiveis de vencer, naõ vindo eu por/ onde vim, principalmente naõ achando no/ Rio de Janeiro a Gomes Freire, me pares-/se naõ chegava cá soldado nenhum, e nes-/tas Minas naõ seria taõ facil reclutar-/se a Companhia, como nas outras pela/ falta de gente, e por que os Soldos saõ pouco/ sufficientes pela grande carestia da terra./

Embarqueime final-/mente a cinco de Agosto (Fig. 11) havendo antes dis-/to ouvido missa na Freguezia, e toda a Com-/mitiva, e acabada ella salvou a Companhia/ de Dragoens com tres descargas a Nossa Se-/nhora da Penha ${ }^{13}$, Invocaçaõ da dita Igreja. Na primeira Canoa me embarquei eu/ só, na segunda os dois Missionarios: na/ terceira os Officiaes da Sala com o Secreta-/rio: na quarta o Capitaõ com metade da/ Companhia. Entre esta, e a do Tenente,/ que marchava na retaguarda com a outra/ metade, hiaõ as de carga; que eraõ só seis/

per-//

\section{Fólio 8v}

pertencentes a EIREy, e quatro a mim, e/ porque ainda naõ poderão acomodar to-/do o mantimento necessario, se tomou mais/ hũa por emprestimo, que me acompanhou/ oito dias. Porem naõ somente estas cha-/madas de carga a levavaõ, mas em todas/ se meteu a que podiaõ acommodar. Nas/ dos Soldados sem embargo de Levar cada/ huma vinte e tantos homens, fóra remeiros,/ e Piloutos, se meteraõ os cunhetes ${ }^{14}$ de balla,/e pederneira, e a roupa perciza para o Cami-/nho, rede, e mosqueteiro de cada Soldado, sem/cujo traste, que Logo explicarei, se naõ po-/de fazer esta jornada; mas sem embargo/ de acommodarem as canoas tanto, como te-/nho dito, havendo algũas que chegarão a/ levar noventa sacos de mantimento, e/ trinta e tantas cargas de barris, e frasquei-/ras, e tendo eu deichado para vir de aluguer/ em outras tropas a maior parte das cargas/tanto de EIRei como minhas, e dos Officiaes/

Sem-//

\section{Fólio 9r}

sempre vos ha de fazer dificuldade, que em/ taõ pouco se acommodasse o mantimento, que/ haviaõ gastar cento e noventa homens em cin-/co mezes, o que procede constar este de feijaõ/ farinha e toucinho, e algũas galinhas só para/ os doentes de maior perigo. Ainda para a/ minha meza este hera o fundamento; por/ que o mais, que levava de paios, prezumptos,/ biscouto, e carnes de vinha dalhos hera á por-/porção do que as canoas podiaõ, e naõ do/ que era percizo./

Supre muito esta falta a/ montaria, e pescaria para o que Levava tres/ canoas pequenas, as quaes vaõ diante pa-/ra pescarem, e cassarem Longe do ruido, que/faz a tropa, e quando se chega ao rancho,/ que ordinariamente hé com duas horas de/ sol vaõ á mesma deligencia, por cuja cau-/za chamaõ estas

13 A primeira capela de Porto Feliz, segundo o livro tombo da igreja, afirma que foi erigida aos pés do rio Tietê e foi dedicada a Nossa Senhora da Penha. A imagem de Nossa Senhora da Penha ainda conservada, feita em terracota, está no altar-mor protegida numa redoma de vidro. Como a freguesia crescia muito foi necessário construir uma grande igreja (a atual), obra iniciada em 1747, em pau a pique e pilão de taipa. A nova padroeira da igreja (naquela época) e atual, entretanto, foi Nossa Senhora Mãe dos Homens. Uma lenda conta que essa imagem de Nossa Senhora Mãe dos Homens chegou à cidade para aguardar a partida de uma monção para ser levada a Mato Grosso. No dia da partida a imagem tornou-se tão pesada que não foi possível levá-la ao batelão e as pessoas entenderam que seu desejo era permanecer em Araritaguaba (ou Porto Feliz). Um azulejo, pintado pelo artista Bruno de Giusti (1920-2011), que se encontra no interor da igreja, ilustra essa lenda.

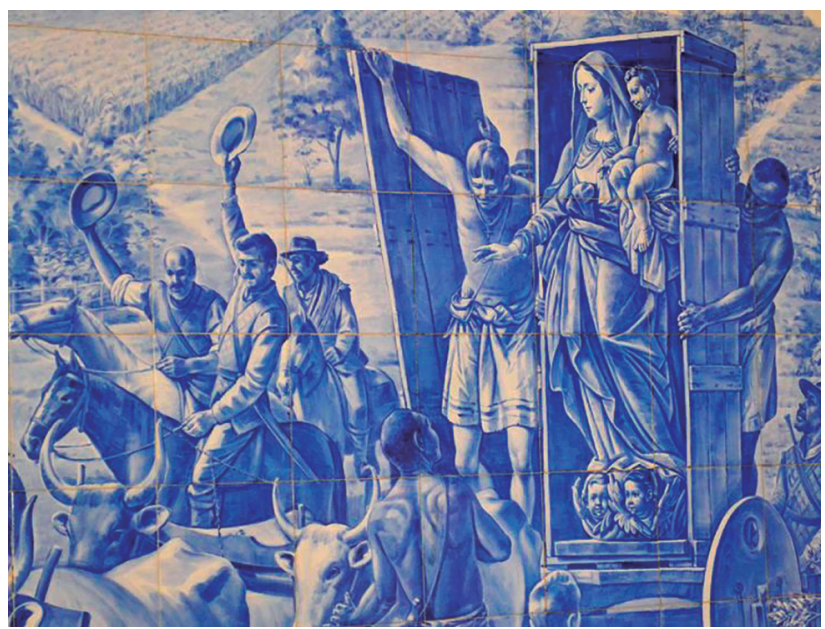

14 Cunhete - caixote de madeira para transportar armas e/ou munição. 


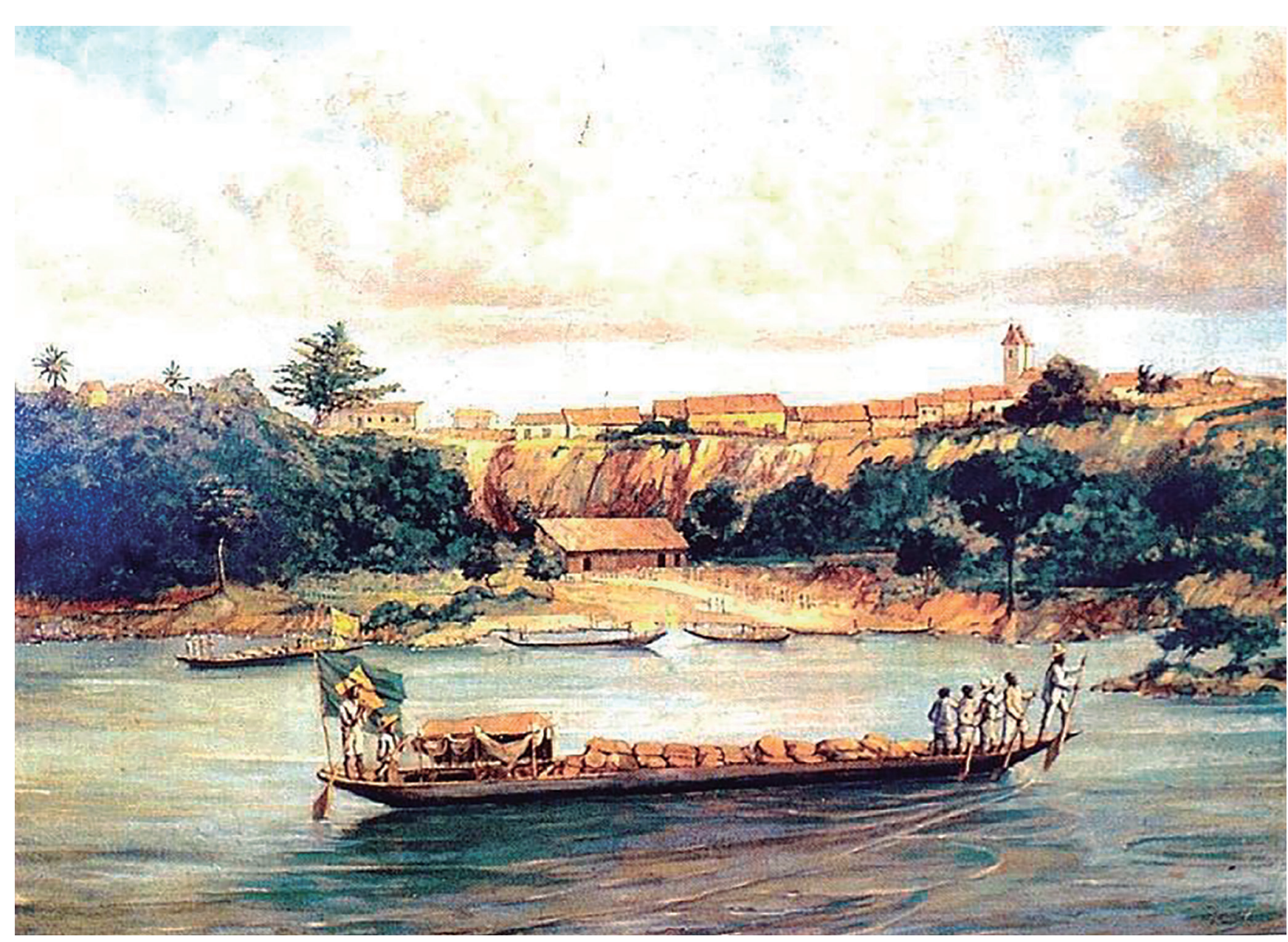

Figura 11. Partida de Porto Feliz (Araritaguaba) (Quadro de Oscar Pereira da Silva, Museu Paulista, Universidade de São Paulo).

canoas de montaria, que/ alem deste serviço saõ precizas a muitos outros,/ como esta narração hirá mostrando. $\mathrm{Va}-\mathrm{I}$

mos//

\section{Fólio 9v}

Vamos á esplicaçaõ dos mosquiteiros. Bem sabe-/reis o grande uzo, que tem nesta terra a rede, a qu-/ al hé a cama mais prompta, e mais facil/ de conduzir; porem como esta só naõ basta/ para Livrar das muitas chuvas, que necessa-/riamente se apanhaõ em hũa travecia como grande de Sertaõ como esta; naõ guarda taõ-/bem da immensidade de mosquitos, que em/ partes se encontrão; para suprir esta fal-/ ta inventarão os viandantes deste cami-/nho o mosqueteiro, que vem a ser hũa Cober-/tura de Linhage, ou de outra droga Leve,/ a qual Lançaõ por sima de hũa Corda,/ que prendem dos mesmos páos, a que attaõ/a rede, por sima della dois palmos. Esta/Cuberta chega até o Chaõ por todas as par-/tes, fechada pelos Lados, e pelas Cabeceiras,/ deichando-Ihe nestas hũas mangas para se/ enfiarem os punhos da rede. Quando cho-/ve cobrem esta máquina com hũa baeta/Cingela da Largura, que baste para alcan-/

çar//

\section{Fólio 10r}

alcançar algũa couza mais abaixo da altu-/ra, em que a rede fca, depois de seu dono deita-/do nella. He incrivel, o que isto reziste ain-/da nas maiores chuvas, do que eu me naõ/ podia capacitar, em quanto o naõ vi, e o vaõ,/ que fica entre a rede, e o chaõ serve como de pequena barraca para todos os uzos da/ vida.

Ao dezamarrar Salvaraõ outra véz/ os Dragoens a N. Senhora com tres descar-lgas, e marcharão as canoas na ordem que/tenho dito, Levando todas bandeiras á pou-/pa com as Armas Reaes. A que hia na/ Canoa da Missaõ as Levava, só de hũa/ parte e da outra o Padre Anchieta. A-/companharaõ-me neste dia 
até o outro ao/jantar o Juiz de Fóra de mato grosso, e outras/pessoas mais. Este primeiro Rio, a que cha-/ maõ Teeté, hé o mais cheio de cachoeiras, e/ das peiores ${ }^{15}$.

O fundo delle he quaze todo/

pe-//

\section{Fólio 10v}

pedra quando esta hé assentada por igual;// mas com pouco fundo de modo, que algũas par-/tes era calhao: ou rossaõ as Canoas, chamaõ a/isto ltaupaba ${ }^{16}$; quando hé dezigual, e com pedras/espalhadas, e em altura debaixo d'agoa que as/canoas correm risco de se virarem, topando nel-/las, Ihe chamaõ Sirga ${ }^{17}$ porque hé necessario lan-/çarem-se os Piloutos, e remeiros á agoa, e levarem/ as canoas ás mãos para as irem desviando de/ vagar sem as deicharem tomar força com a cor-/renteza, que ali hé sempre maior (Fig. 12). Se em al-/gũa parte deichaõ estas pedras canal aberto/fundo, hé as que chamaõ cachoeira, que ordina-/riamente os há, aonde há Sirgas; mas mui-/tas vezes se servem destas, quando achaõ dificul-/dade grande nos Canaes. Estas differenças es-/taõ debaixo d'agoa, e os Piloutos as Conhecem tan-/to pela experiencia, e memoria, como pelo mo-/vimento da mesma agoa, o qual se mostra aon-/de hé fundo, ou baixo, aonde há canal ou pedras./Porem alem desta Siencia necessitaõ taõbem/

15 Teotônio José Juzarte (1769) (cf. Papavero \& Teixeira, 2007: 245-246) listou as cachoeiras do rio Tietê:

\begin{tabular}{|c|c|}
\hline Nomes das Caxuras & Tradução \\
\hline 1 Caxur Avarémanduava & Onde foi a piq' hũ Jezuita \\
\hline 2 Caxur Itanhaem & Pedra q'falla \\
\hline 3 Caxura $^{\text {Ixaxirica }}$ & Agoa q'ferve \\
\hline 4 Caxur Itagaçava & Lage $q^{\prime}$ atravessa o $\mathrm{R}^{0}$ \\
\hline 5 Caxur $^{\text {a Pirapóra }}$ & Onde saltaõ os peixes \\
\hline 6 Caxura Bujuyquara & Buraco de Cóbra \\
\hline 7 Caxura Diangoá & Piloens \\
\hline 8 Cacur ${ }^{\mathrm{a}}$ Itapema & Pedra quebrada \\
\hline 9 Caxur $^{\mathrm{a}}$ Dugarcia & Perdeo-se este homẽ nela \\
\hline 10 Caxur ${ }^{\mathrm{a}}$ Mathias peres & Perdeo-se este homẽ nela \\
\hline 11 Caxur Itabucava & Pedras de Espingarda \\
\hline 12 Caxur ${ }^{a}$ Ipicú & Estiraõ comprido \\
\hline 13 Caxur Putunduva & Onde a vista se faz escura \\
\hline 14 Caxura Ibauruguassú & Onde se perdeu um baú grde \\
\hline 15 Caxur ${ }^{\mathrm{a}}$ Baruery mirim & Frutas Barueris pequenas \\
\hline 16 Caxura Baruery guassú & Frutas Barueris grãdes \\
\hline 17 Caxura Gyaymicanga & Óssos de Velha \\
\hline 18 Caxur ${ }^{\mathrm{a}}$ Avenhandava & Onde correm os homens \\
\hline 19 Caxura Bracaé & Escramuça do Gato \\
\hline 20 Caxur Itúpanema & Caxueira falhada \\
\hline 21 Caxura Yayvapirú & Mato seco \\
\hline 22 Caxur Icacoara quassú & Ondas grandes \\
\hline 23 Caxur ${ }^{\mathrm{a}}$ Funil & Há duas deste nome \\
\hline 24 Caxur ${ }^{a}$ Vacurituba & Onde há palmitos \\
\hline 25 Caxur $^{\mathrm{a}}$ Arassaruva & Frutas do Arassá \\
\hline 26 Caxura ${ }^{\text {A }}$ raracanguara mirm & Cabeça de Arara pequena \\
\hline 27 Caxur ${ }^{a}$ Araracabguara guassú & Cebeça de Arara grande \\
\hline 28 Caxur ${ }^{\text {It tupeva }}$ & Caxur ${ }^{\mathrm{r}}$ raza \\
\hline 29 Caxura Anhangaratá & Canal do Inferno \\
\hline 30 Caxur ${ }^{\text {Y Ytupeva mirim }}$ & Caxura baixa e pequena \\
\hline 31 Caxur Itupirú & Caxur baixa e seca \\
\hline 32 Caxur ${ }^{\mathrm{a}}$ Ytaipiranga & Pedra Vermelha \\
\hline 33 Caxura Itapura mirim & Ponta de Pedra pequena \\
\hline 34 Caxura Itapura quassú & Ponta de Pedra grande \\
\hline
\end{tabular}

Estas saõ as Caxurass $q^{\prime}$ passamos de mayor perigo, alem de outras q' tambem saõ de perigo, q' abaixo declaro.

\begin{tabular}{|c|c|}
\hline Nomes das Caxueiras & Traduçaõ \\
\hline 35 Caxur ${ }^{\mathrm{a}}$ Decó & da Róssa \\
\hline 36 Caxur $^{2}$ do Cubas & Perdeo-se este homẽ nella \\
\hline 37 Caxura Yvauru mirim & Perdeo-se nella um baú \\
\hline 38 Caxura Sapetuva mirim & Tetal pequeno \\
\hline 39 Caxur $^{\mathrm{a}}$ Cogoanhan & Congonhas \\
\hline 40 Caxura Jacaré pepira & Sobrancelhas de Jacaré \\
\hline 41 Caxura da Ilha & da llha \\
\hline 42 Caxur ${ }^{\mathrm{a}}$ Cambalhetuva & Astes de Fréxas \\
\hline 43 Caxur ${ }^{\mathrm{a}}$ Tambay & Vazo dem er cheyo de agoa \\
\hline 44 Caxur ${ }^{\mathrm{a}}$ Tambapiririca & Vazo dem ${ }^{\text {er }}$ que ferve \\
\hline 45 Caxur ${ }^{\text {a }}$ Cambagevoca & Cana raxada \\
\hline 46 Caxur ${ }^{\mathrm{a}}$ tupereva & Caxura da ferida \\
\hline
\end{tabular}

16 Itaipaba ou itaipava - banco de seixos ou pedregulhos nos leitos dos rios.

17 Um caminho de sirga é um caminho ao longo das margens de um rio ou canal e que tem como objetivo permitir a tração de barcos por meio de animais ou pessoas. A sirga era o cabo (corda) de sisal utilizado para rebocar os barcos a partir da margem. Esta solução era frequentemente utilizada quando a navegação à vela era impossível, por exemplo, devido à existência de correntes fortes. 


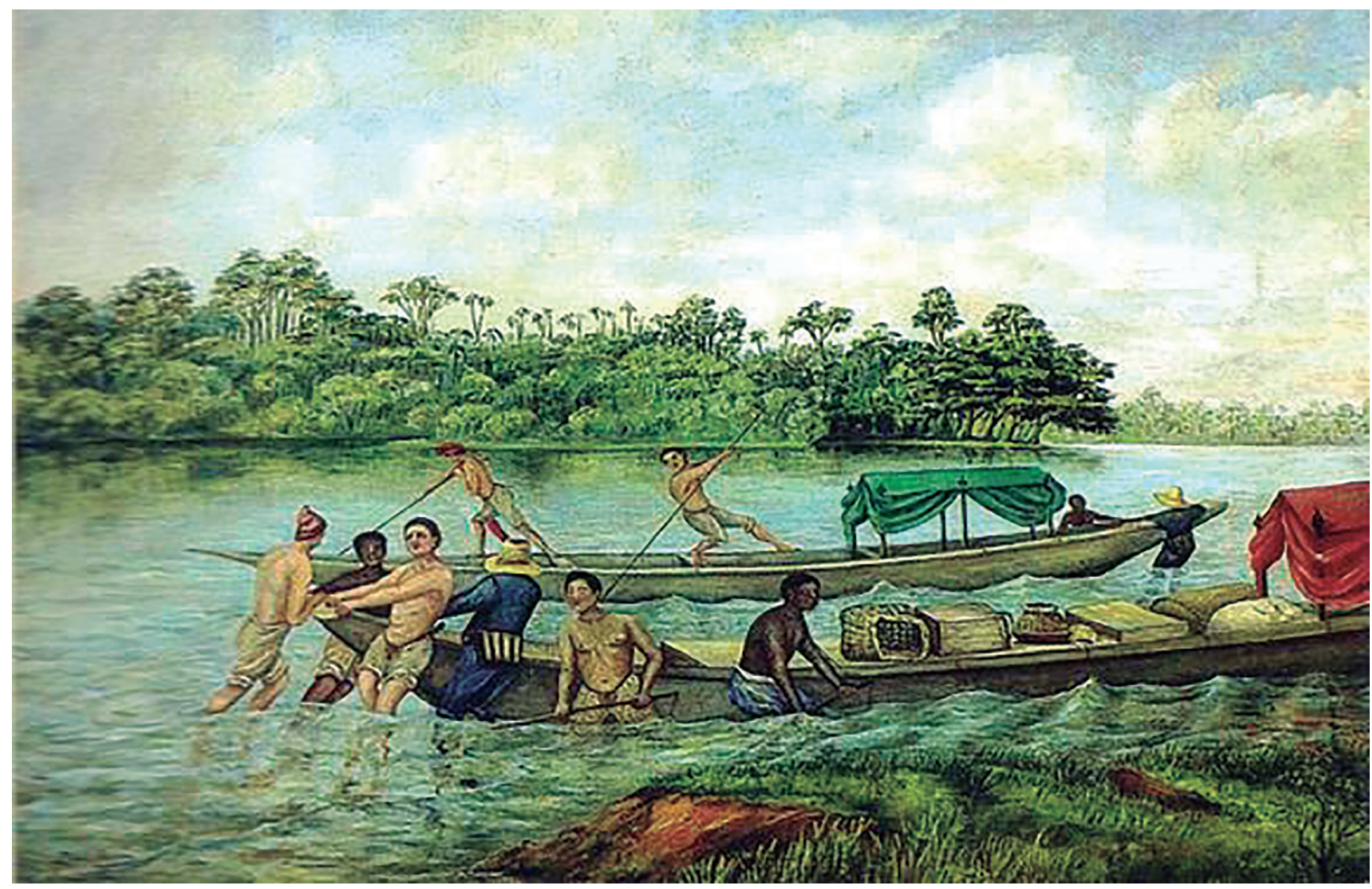

Figura 12. "... porque hénecessario lan-/çarem-se os Piloutos, e remeiros á agoa, elevarem as canoas ás mãos para as irem desviando de vagar sem as deicharem tomar força com a correnteza, que ali hé sempre maior" [Fólio 10v].

\section{Fólio 11r}

da que Ihes encina a regular forma porque/ se haõ de haver em todos estes passos. Huns vaõ/ buscar da mesma sorte, e com a mesma gente,/ que trazem, em outras poem nas canoas tu-/do piloutos em Lugar de Remeiros, em alguns/se tiraõ ás canoas meias cargas, e em outros/todas. Para dispôr todas estas manobras se/ escolhe sempre hum Pilouto mais capaz, a/ que chamaõ guia, o qual vai diante para os ou-/tros se hirem governando por elle. Nas Cacho-/eiras deficultozas passaõ estes muitas vezes só/ diante em canoa pequena para as examina-/rem fazendo entre tanto parar a tropa, a qu-/al vem buscar depois estando já certos do co-/mo se hão de haver. Finalmente hé hũa/ arte esta maior do que se reprezenta á pri-/meira vista; pois hé necessario estarem es-/tes homens com Lembrança em hũa via-/ gem taõ comprida de mais de Cem cachoei-/rãs, que ella tem e da parte, e forma porq'/ as hão de tomar, sendo taõ diversas, naõ só/

entre//

\section{Fólio 11v}

entre si, mas cada hũa de si mesno á medida que/os rios Levaõ mais, ou menos agoa, e havendo al-/gũas taõ compostas, que parte se passa á Sir-/ga parte a remo. \&a. Hũa houve que por es-/ta cauza gastei nella tres dias.

Duas Lego-/as abaicho do porto está aquella Celebre/ Cachoeira, a que chamaõ na Lingoa da terra/ Avaré-manduaba ${ }^{18}$, que quer dizer - Lembrã-/ça do Padre Anchieta-, escapando elle mila-/grosamente, como relata a sua vida, e hé tra-/diçaõ constante naquellas partes./

18 Segundo o "Roteiro verdadeiro das minas do Cuiabá, e de todas as suas marchas, cachoeiras, itaipavas, varadouros e descarregadouros das canoas, que navegam para as ditas minas, com os dias de navegação, e travessia, que se costumam fazer por mar e terra, de autor anônimo" (cf. Papavero \& Teixeira, 2007: 202): "Daqui a meia volta do mesmo rio [Tietê] se vai sempre à mão esquerda entrando 0 boqueirão até avistar a cachoeira, chamada Abaremanduaba, que quer dizer lugar ondeo Padre mergulhou. Deu-lhe este nome o Ven. Padre José de Anchieta, quando voltando-se-lhe a canoa neste lugar, e buscando-o de mergulho o gentio, 0 acharam no fundo rezando um breviário....". E segundo Teotônio José Juzarte (1769; cf. Papavero \& Teixeira, 2007: 229): ". . . chegamos a hũa cachoeira chamada Abaramanduaba q' quer dizer em Portuguez a onde cahio hũ Padre. Em outro tempo navegou por esta Caxueira um Religiozo da Compa de JESUS, de virtude chamado o Pe Jozé de Anxeta, o qual andava Catequizando aos Indios, e pregando-lhe Missão, os quaes vindo com elle em hũa Canoinha a emborcarão no meyo desta Caxueira, largando ao Pe no fundo da mesma; passado $\mathrm{m}^{\text {to }}$ tempo vendo $\mathrm{q}^{\prime}$ o $\mathrm{p}^{\mathrm{e}}$ naõ surgia acima e cuidando estaria já morto margulhou hũ dos Indios ao fundo, e o achou sentado em hũa Pedra rezando no seu Breviario, e por isso ficou a esta esta Caxueira de Abaramanduaba". 
Dali/ hum dia de viagem se encontra outro Prodi-/gio ainda que de diferente especie. Haverá/ huns poucos de annos se cituou naquella/paragem hum homem taõ só, e dezacompa-/nhado, que nem ainda cão, nem espingarda/ tinha com sigo, por cuja cauza chamavaõ/ ao mesmo Citio do - Homem só, sem embar-/go do que fazia horta, plantava, cassaval

tanto//

\section{Fólio 12r [10.08.1750]}

tanto a caça do ar como a do Chaõ, tudo com arte, e/ e [sic] engenho, que Ihe facilitava estas couzas. Fazia Canoas, em que andava para baixo, e para si-/ma estando no meio de hũa das peiores cacho-/ eiras, que há no caminho. Alguas vezes se-/metia ao mato quinze e vinte dias sem espin-/garda nem cão, como já dice. Quando eu/passei já estava cazado, mas fora essa naõ/ tinha outra Companhia.

A dez fiqueil arranchado ao pé de hum morro, aonde ouvi/ por duas vezes estrondos, como de Artelha-/ria, e parecendo-me que serião trovoens, me/ segurarão os Piloutos, serem estalos, que dava/ o mesmo morro, e que alguns praticos tinhaõ/ aquillo por signal de haver ali ouro, e que/ querendo-o examinar varias vezes, se naõ/ atreverão a chegar perto pelo horror, que/ Ihe fizeraõ os ditos estrondos. Na verdade/ o Ceo estava mais, como defumado, e se-/milhante ao que se vé na altura de Cabo ver-/

\section{Fólio 12v [18.08.1750]}

que he de trovoada. A doze passei pelo ul-/timo Sitio, que se encontra até Camapuan,/ aonde estaõ vivendo dois moradores com al-/guns carijós fóra de toda a communicaçaõ/mais do que com aquelles, que fazem o ca-/minho de Cuiaba [sic]: chamaõ a este Lugar/Pitunduba.

A dezouto passei por hum La-/ranjal, que está dentro do mato sem cul-/tura algũa, e com tudo as Laranjas saõ/ maravilhozas, e no mesmo dia cheguei ao Salto de Avenhamdaba ${ }^{19}$ (Fig. 13). Neste Lugar/leva já o Ryo maior Largura, que o al-/cance de hũa bala de espingarda, e de-/pois de hir bastante distancia por si-/ma de pedras fazendo grandes Cachoens,/ cahe toda aquella agoa de mais altura/ que hũa Lança, formando a pedra pela es-/querda a figura de hũa concha aonde se/ vê estar o peiche continuamente saltando/ para sima para apanhar altura, $q^{\prime}$ '

ali//

\section{Fólio 13r [02.09.1750]}

ali hé menor. Hera aqui tanta a quantida-/de de peiche, que com fisgas, e paos se matava./Neste e outros semilhantes Lugares se tiraõ/ as cargas ás Canoas, e se passa hũa, e outra/ couza por terra, o que cauza grandes demoras.

A dois de Septembro che-/guei ao salto de Itapura (Fig. 14), aonde taõbem de-/pois de hum baixio de Lage, forma ella/ Como hum tanque ovado aberto só pela/ parte de baixo, e em roda delle cahe a agoa/ de muito maior altura, que no anteceden-/te. No meio se levanta hũa llha, ou/ reducto de pedra. Aqui foi tanta a quan-/tidade de peiche, que se pescou, que muito/ se tornou a deitar ao Rio por naõ haver já/ quem o quizesse, sem embargo de que ali ti-/vemos tres dias de demora. Matou-se taõ-/bem hua cobra securi20 de dezassete palmos de/ comprido, e no mais grosso como a coixa da/ perna. Estas ordinariamente andaõ n'agoa,/Sahem alguas vezes á terra, naõ saõ peçonhen-/

tas//

\section{Fólio 13v}

peçonhentas; o mal, que fazem, he tendo aonde/ segurar o rabo, aquillo em que se enroscaõ, in-/ falivelmente o puchaõ para a agoa (Fig. 15). Alem/ destes dois saltos passei neste rio entre Ita-/puiabas, cachoeiras, e sirgas secenta e hum, em algũa das quaes se tirarão meias cargas/ás canoas, e em muitas houve grandes de-/moras. A isto se ajuntava naõ poder sa-/hir do pouzo ordinariamente antes das no-/ ve horas por cauza da nevoa, o que dilata/ muito esta viagem.

19 Avanhandava.

20 Sucuri - Eunectes murinus (Linnaeus, 1758). A crendice de que certas cobras enroscam o rabo numa árvore para poder atacar uma presa, notadamente veados, aplicava-se sobretudo à jiboia (Boa constrictor Linnaeus, 1758), por tal razão também conhecida na antiga literatura como cobra-de-veado. 


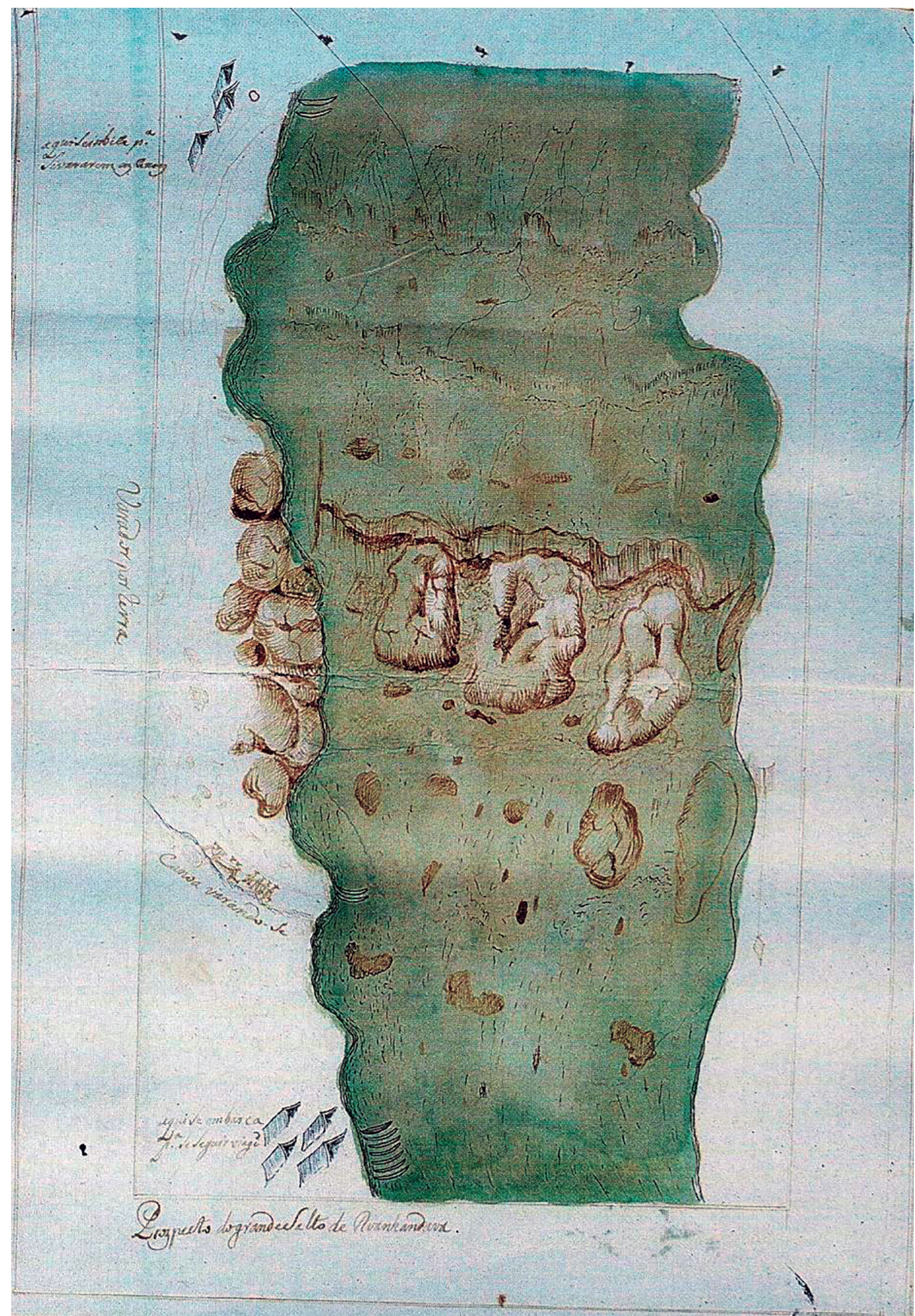

Figura 13. Estampa s/nº de Teotônio José Juzarte (1769), em Souza \& Makino (2000: 385): “Prospecto do grande Salto de Avanhandava, [No lado esquerdo da estampa estão assinalados os pontos onde foram embicadas as canoas no barranco, para passarem o trecho pelo varador por terra e o ponto abaixo do Salto, onde se embarcou para seguir viagem]". 


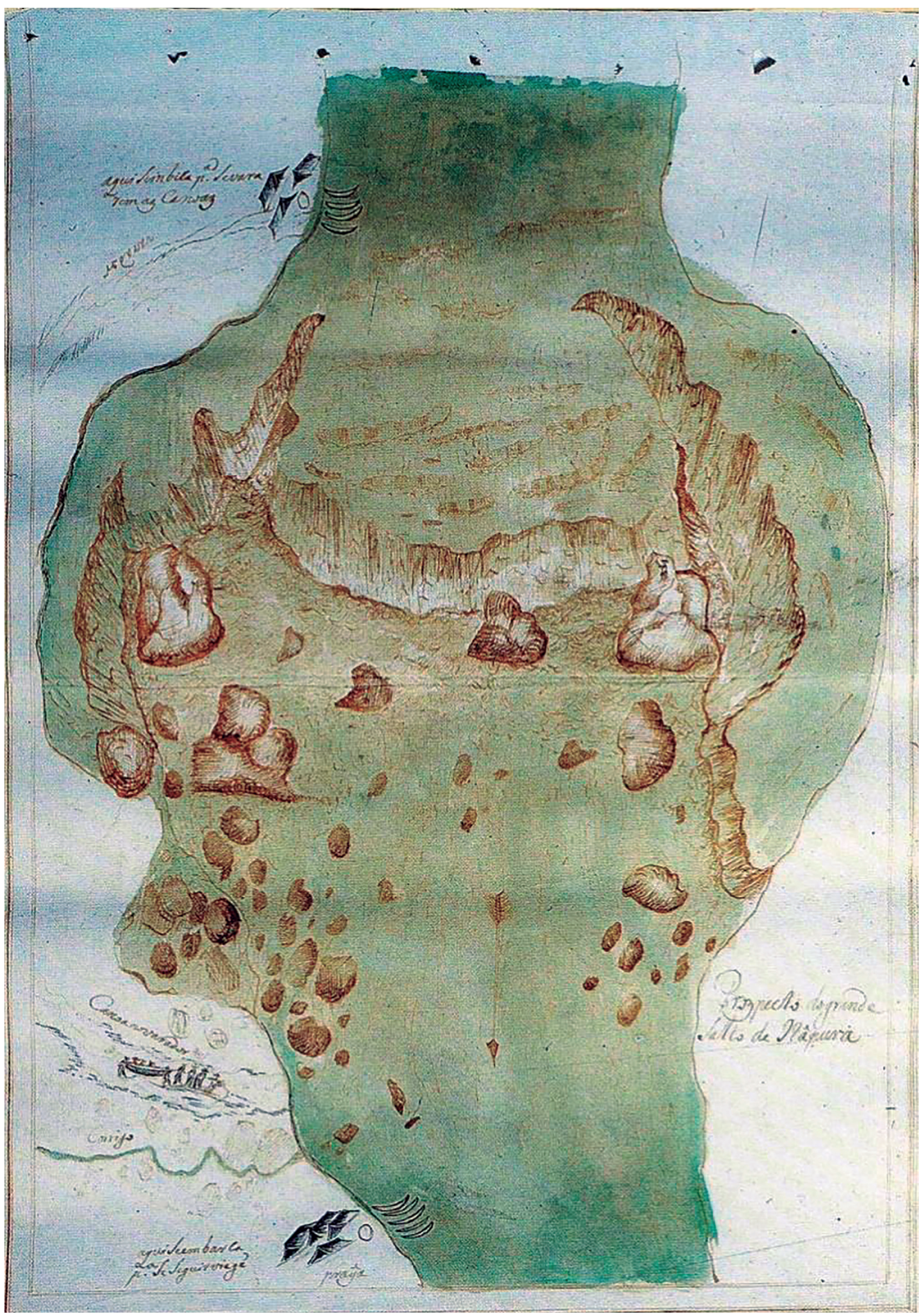

Figura 14. Estampa s/no de Teotônio José Juzarte (1769), em Souza \& Makino (2000: 394):"Prospecto do grande Salto de Itapura. [No alto da estampa lado esquerdo: "'Aqui se embica para se vararem as canoas', depois é indicado o local do varador e logo abaixo, também no lado esquerdo, Juzarte desenhou homens arrastando uma canoa no varador. No canto inferior esquerdo está anotado: 'Aqui se embarca para se seguir viagem']". 


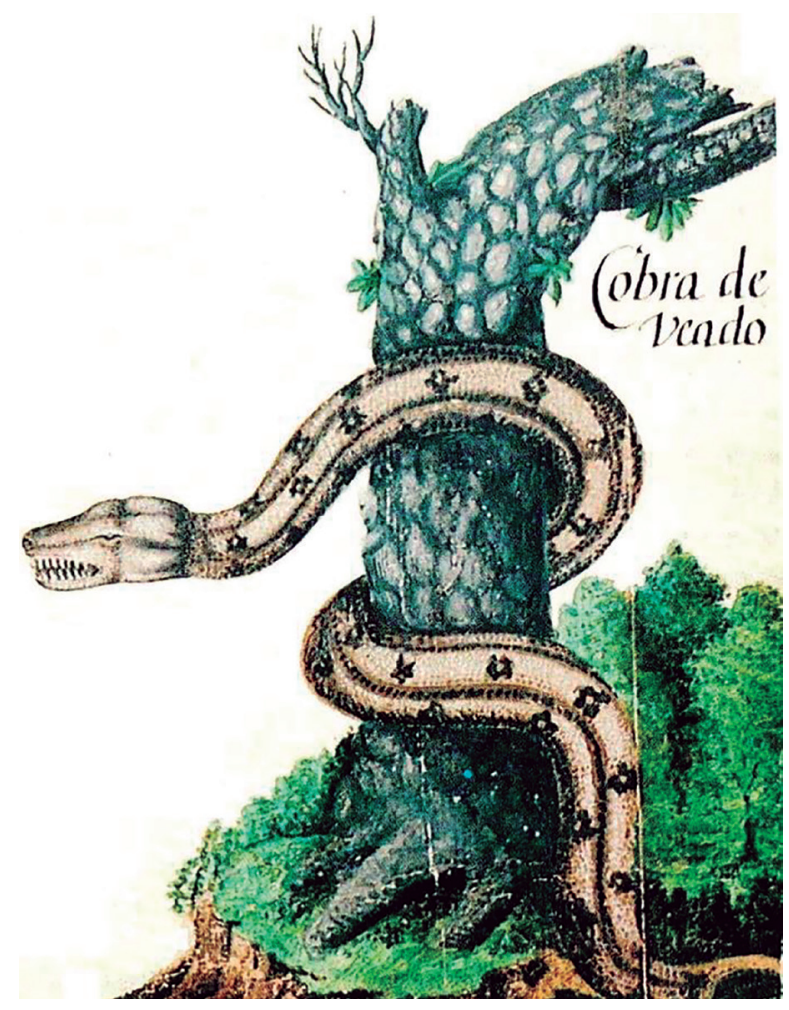

Figura 15. "Sahem alguas vezes á terra, naõ saõ peçonhentas: o mal, que fazem, he tendo aonde segurar o Rabo, aquillo em que enroscaõ, infalivelmente o puchaõ para a agoa" [Cobra-de-veado, Zacharias Wagener, Thier Buch, séc. XVII), in Teixeira (1997: 161)].

De onze de Agos-/to por diante comessei a ter cassa, e depois/poucos foraõ os dias, em que me faltou./ Patos bravos maiores, e mais gostozos, do q'/ os do Reino; e outra Casta de pássaros, a que/ chamaõ Joos ${ }^{21}$ (Fig. 16) [sic] do tamanho de perdizes, e com/ algũa semilhança no gosto; em certas paragens muita quantidade de Papagaios,/ os quaes naõ saõ maos com arróz. Há/ em algũas partes hũa casta de barro/

que//

\section{Fólio 14r}

que os passaros comem; mas nem todos gostaõ/do mesmo, e lhe chamaõ barreiros daquella es-/pecie de passaros, que ali vaõ. Topando-se/ com elles, sem hua pessoa se tirar de hum/ lugar, mata a quantos quer; por que elles/se naõ afastaõ. Alem destes se mataraõ/outros, que naõ saõ Capazes de se comerem,/ entre os quaes foraõ huns, que se chamaõ Tui-/uius ${ }^{22}$ (Fig. 17), que postos em pé saõ mais altos, q'/ hum homem. Da caça de pello neste/ rio só vi Pacas ${ }^{23}$ (Fig. 18) e Capivaras $^{24}$ (Fig. 19). As primei-/ras saõ do tamanho de hum Leitaõ com/os péz curtos, o pello como de caõ pardo es-/curo. Das outras o feitio hé de rato prin-/cipal-mente a Cabeça: o pello na aspereza/ hé de porco, mas pardo: saõ do tamanho de/ hum marrão, e o gosto naõ hé bom, a Paca/ sim, he mui gostoza./

Naõ foi menor a/abundancia de peixe, ainda fóra dos Lugares,/ que já disse, a maior parte Dourados ${ }^{25}$ (Figs. 20 e 21). Alguns/

\section{Fólio 14v [05.09.1750]}

se pescaraõ, que custava a hum homem le-/vanta-los; os communs eraõ como gorazes./ Há outra espécie, a que chamaõ Jaús ${ }^{26}$ (Figs. 20 e 22), que/ saõ de pele, muito maiores, que os dourados:/ para me trazerem hum á mostra, foi ne-/cassario carregarem-no dois homens./

21 Jaó - Crypturellus noctivagus (Wied, 1820). “Jacus", erroneamente, na leitura de Varnhagen (1846: 478).

22 Tuiuiú - Jabiru mycteria (Lichtenstein, 1819).

23 Paca - Cuniculus paca (Linnaeus, 1758).

24 Capivara - Hydrochoerus hydrochaeris (Linnaeus, 1766).

25 Dourado - Salminus brasiliensis (Cuvier, 1816).

26 Jaú - Zungaro jahu (Ihering, 1898). 


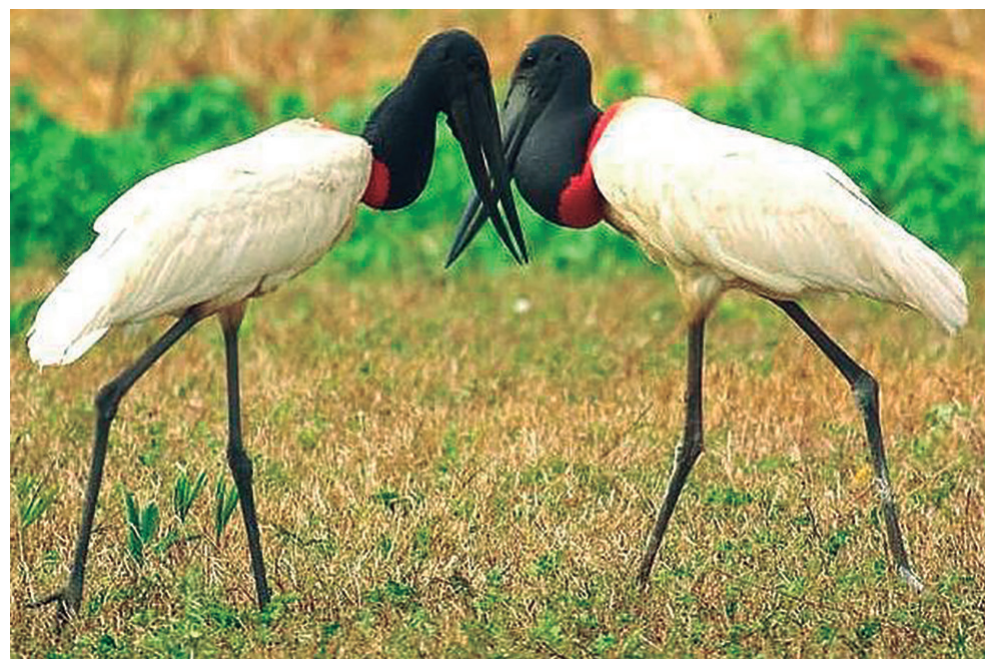

Figura 16. Jaó.

Figura 17. Tuiuiús.

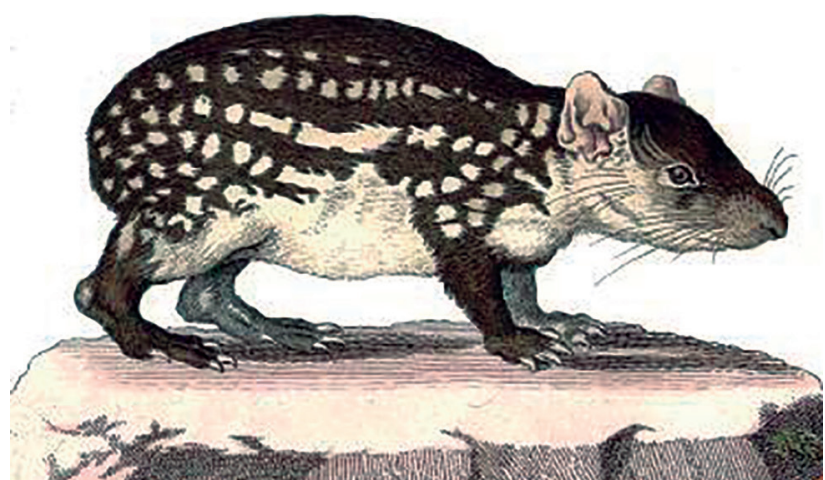

Figura 18. Paca.

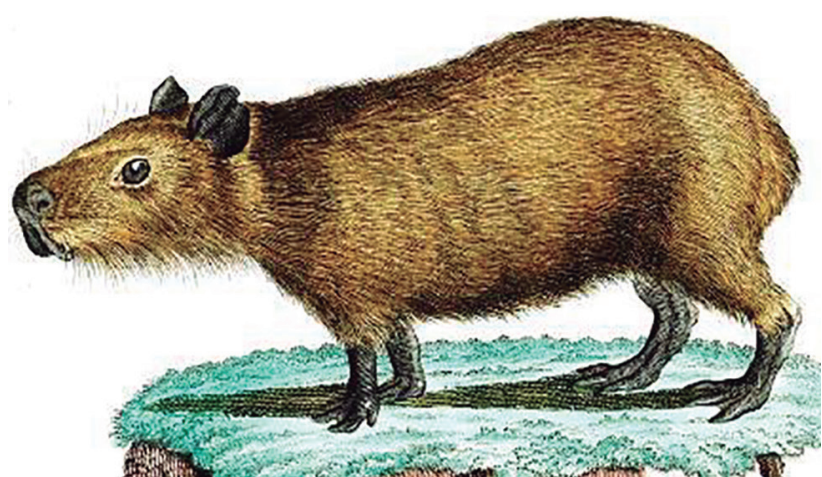

Figura 19. Capivara.

Porem tudo isto faltou tanto que em-/trei no Rio Grande, que foi a cinco de Septem-/bro de tarde. A sua grande Largura, que em/ partes hé de meia Legoa, e os estiroens mui-/to compridos, que tem, daõ Lugar a que o ven-/to faça nelle maior impressaõ, principalm ${ }^{\text {te }}$ o Sul, que as Canoas naõ podem rezistir/ ás ondas, que Levanta. Se está perto algũa/ abrigada, hé o unico refugio; mas como estas/ saõ raras, se tem visto naquelle rio muitas/ alagaçoens, e poucos foraõ os piloutos da mi-/nha comitiva a quem a naõ tivesse suce-/dido, ou ao menos se naõ vissem em gran-/de perigo. Este Rio hé o mesmo, que nos/mapas vem com o nome de Paraná, quel

se-/

\section{Fólio 15r}

se vai meter no Paraguay junto a Cidade de/ Corrientes. Forma como o Teeté hum angu-/lo agudo da parte das cabeceiras, o qual en-/tra nella pella sua esquerda. Dizem os Ser-/tanistas, que abaixo da barra do rio Pardo/tres dias de viagem se some todo por baixo da/terra em hũa grande Cachoeira chamada/ as Sette quedas ${ }^{27}$. A sua agoa hé turba; $e /$ mal cheiroza, e nas vazantes costuma cau-/zar sezoens malignas./

Há nelle hum celebre/ passo, que chamam Jupia ${ }^{28}$ (quer dizer covo/na Lingoa da terra) o qual hé hum rede-/moinho, aque a agoa faz nesta figura bas-/tante Largo, e fundo, e a agoa corre com vio-/lencia para aquella parte de tal sorte,/ que hé necessario passar o mais distante/daquella parte, que pode ser, e

270 Salto de Sete Quedas, também chamado Sete Quedas do Rio Paraná, em espanhol: Saltos del Guairá, foram as maiores cachoeiras do mundo em volume de água, com $13.300 \mathrm{~m} / \mathrm{segundo}$, sendo 0 dobro de volume d'água das Cataratas do Niagara na divisa EUA/Canadá e treze vezes mais caudalosas que as Victoria Falls na Zâmbia. Seu som poderia ser ouvido a 30 km de distância, seu canal principal possuía 4 km de comprimento e profundidades que variavam entre 140 e 170 metros. Desapareceram com a construção da Usina Hidrelétrica de Itaipu.

28 Jupiá - nome indígena que significa redemoinho, voragem. 


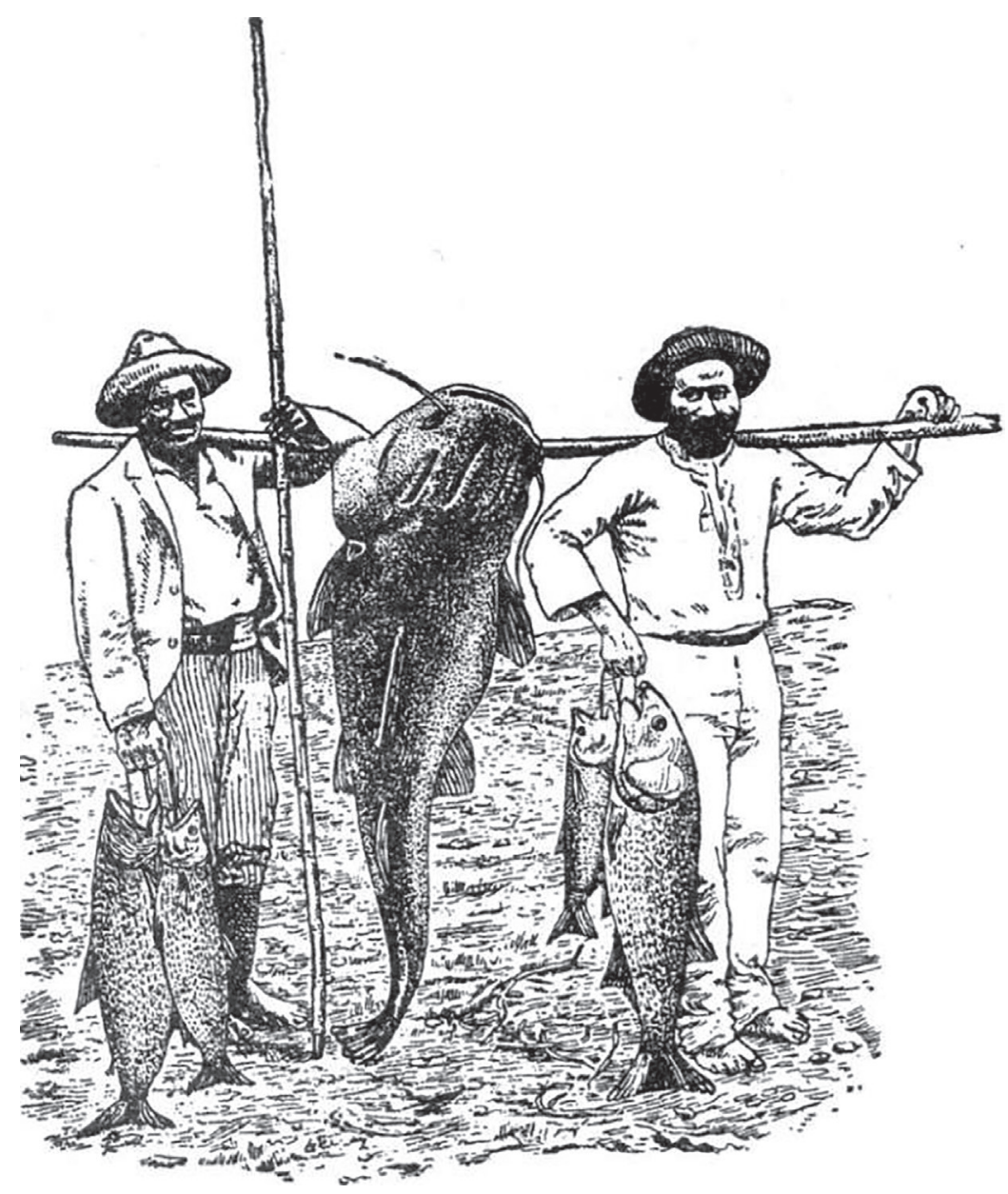

Figura 20. Jaú e dourados (Rodolfo von Ihering, 1940: 437).

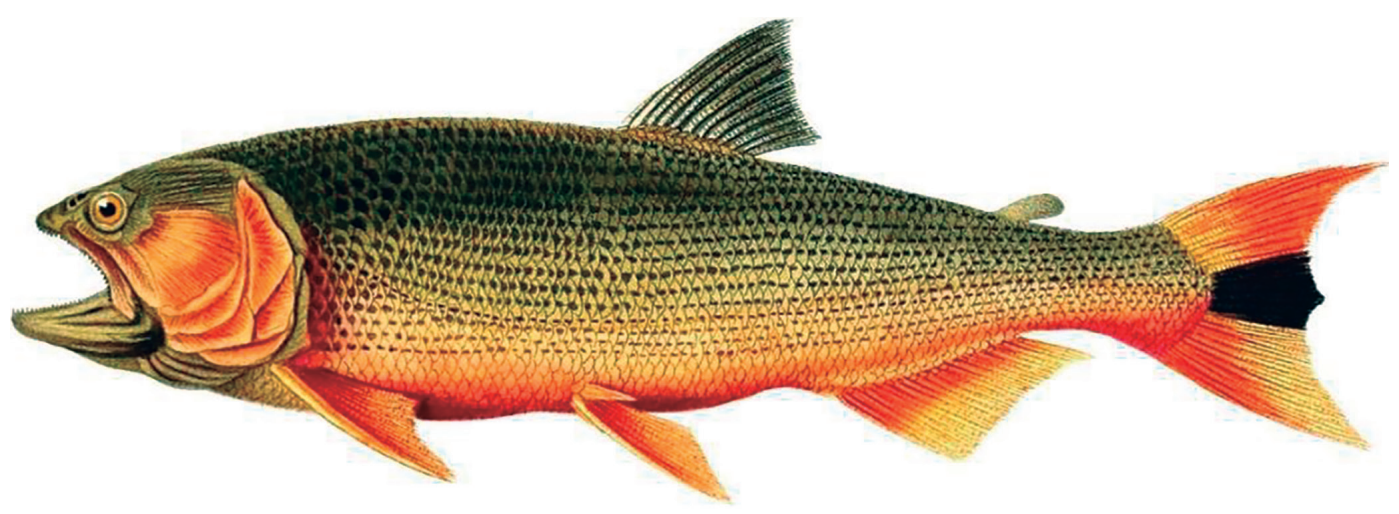

Figura 21. Dourado.

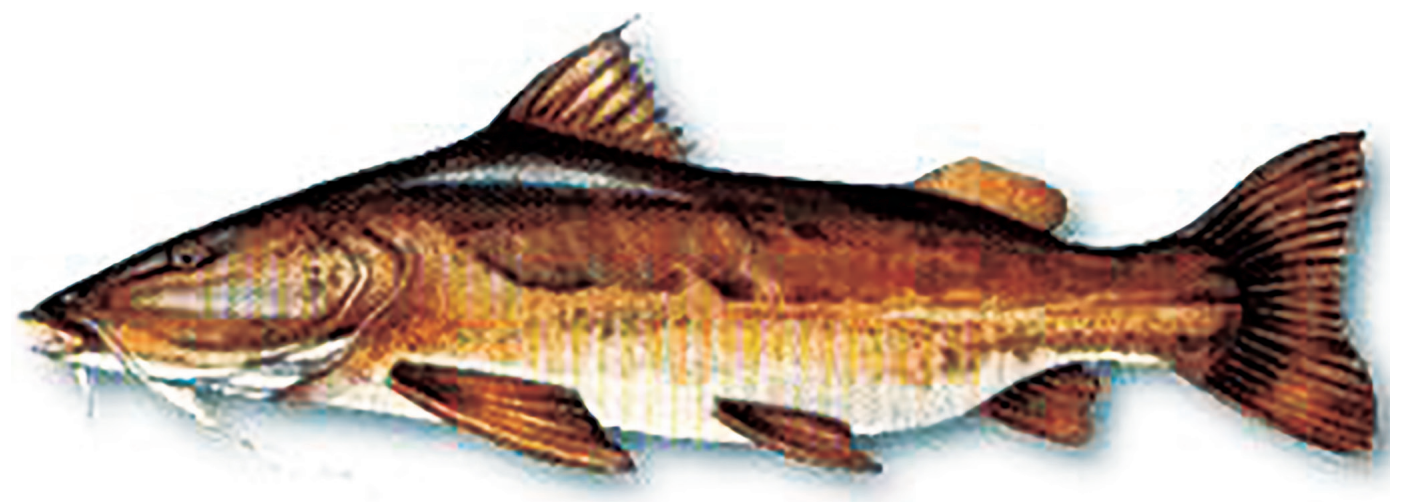




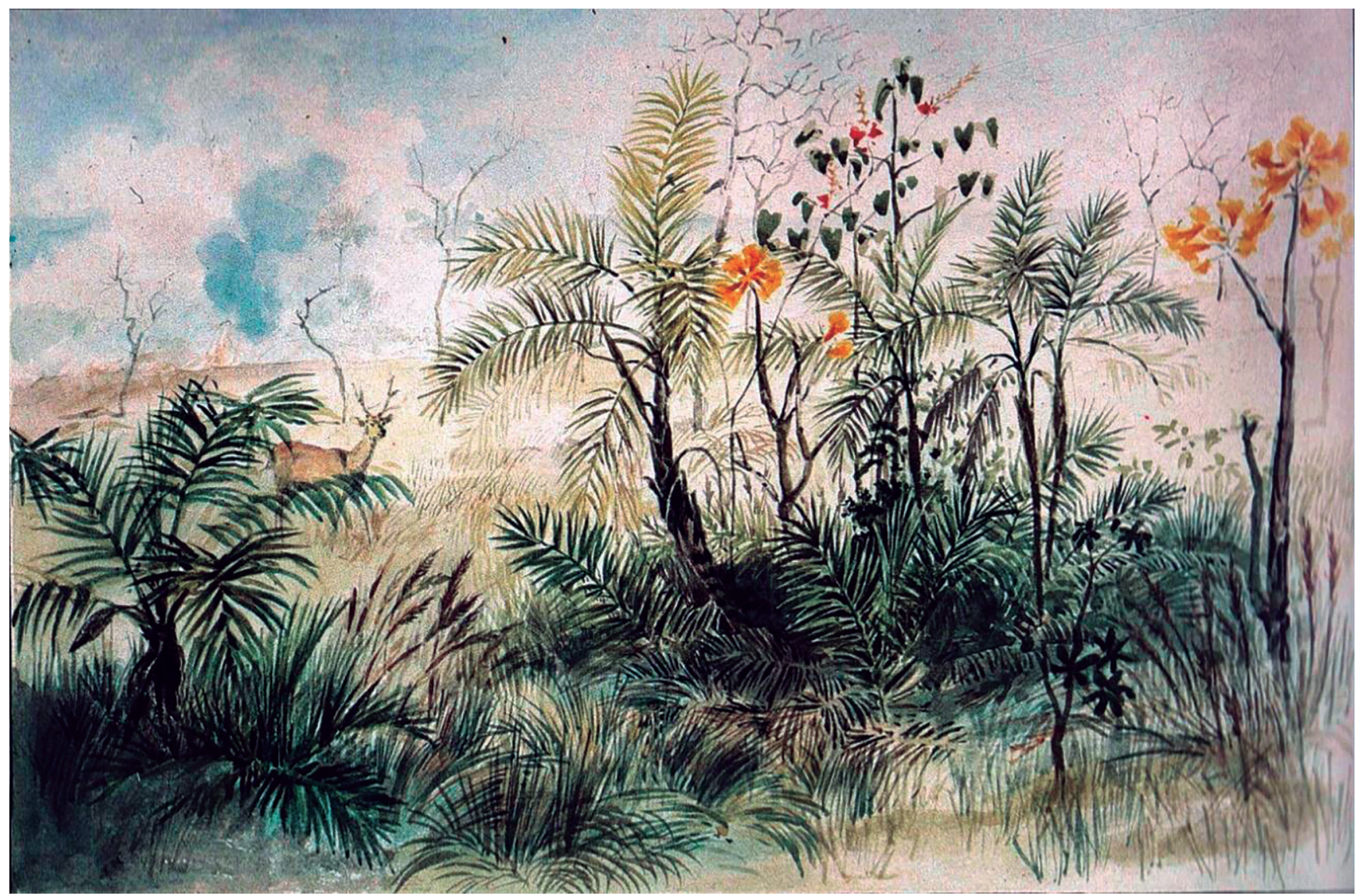

Figura 23. Campo perto do Rio Pardo (Aimé Adrian Taunay, 1826 [Taunay (A.A.), 1988 108]).

fazendo/grande força de remo, porque se chegaõ a/ dar ali as Canoas, infalivelmente as sorve a a-/goa. Esse perigo e o de vento encontrei no dial

seis//

\section{Fólio 15v [09.09.1750]}

seis, mas de ambos Livrei com bom sucesso.

A nove ao/ jantar entrei no Rio Pardo, que hé sumamen-/te trabalhozo para os Piloutos, e Remeiros. So-/be-se ás varas com muito custo pela grande/violencia da Corrente. Passei nelle cincoenta e qua-/tro Cachoeiras (Fig. 24), nove vezes se descarregarão as/Canoas de todo, e quatro se passarão com me-/ias cargas, varando-se huas vezes por terra,/ e outras por sima de pedras no mesmo Rio./ A agoa delle hé maravilhoza ao principio,/ e em quanto as trovoadas para a parte do ver-/melho a naõ perturbaõ: há hum pequeno/ ribeiraõ, que se mete no rio Pardo pouco abai-/xo do Porto da Sambexuga. Quando nelle/ Chove com força tinge o rio Pardo até á barra/de vermelho, que hé a cor, que o dito Ribeiraõ/trás sempre. Porem como os mais ribeiros,/ e Corrigos, que nelle se metem, que saõ mui-/tos tem todos excelentes agoas, naõ faz aquil-/lo prejuizo aos passageiros; pois tem sem-/

pre//

\section{Fólio 16r}

sempre aonde se proverem á sua vontade. As/margens deste Rio saõ campinas muito Lar-/gas com seus Capoens de mato de distancia em/ distancia (Fig. 23), as quaes trazem bastantes perdizes ${ }^{29}$ (Fig. 25),/ Saõ da mesma Côr das nossas, mas naõ tem/ pena real, nem as pernas vermelhas: $O$ ta-/manho hé de hũa galinha, e ainda que naõ/ chegaõ ás nossas no gosto, sempre saõ bastan-/temente saborozas. Os embaraços e vagares do/ rio me deraõ Lugar muitas vezes de hir a es-/te divertimento, para o que a terra 


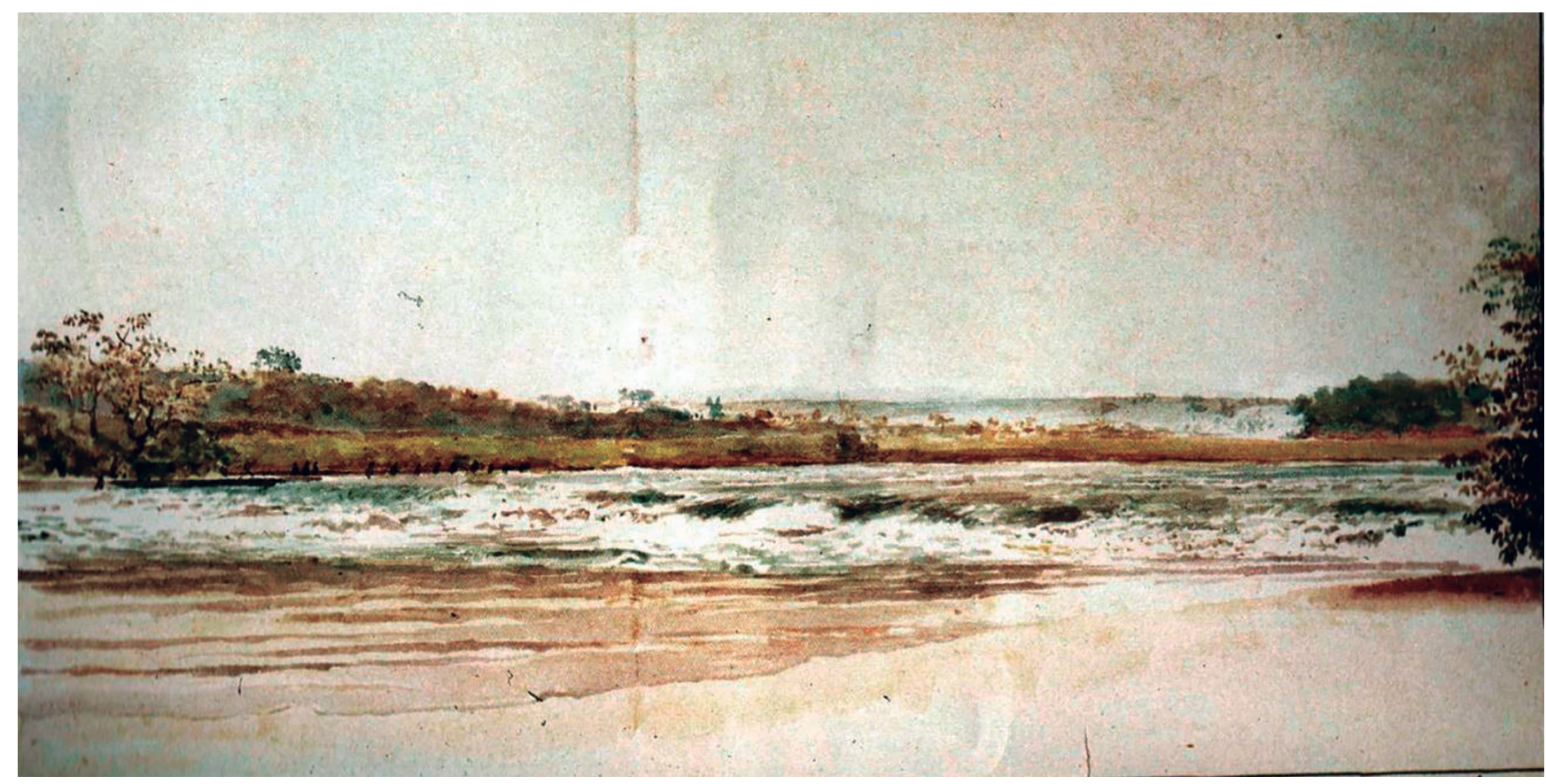

Figura 24. Cachoeira no Rio Pardo (Aimé Adrian Taunay 1826 [Taunay [A.A.), 1988: 109]).

hé su-/mamente Cõmoda por ser muito plaina,/ cortada de Corrigos de excelentes agoas, e/ cheia de varias futas [sic, frutas], que nascem em ra-/minhos Curtos por entre o capim. Destas as/mais especiaes saõ os cajúz, e taõbem as del que há maior abundancia. Alem desta Cas-/sa há Cervos, que saõ do mesmo feitio, e pouco mais pequenos, que os nossos viados. Há vi-/ados do tamanho de Cabras, mas a carne ma-/is tenra, e gostoza, que a dos nossos. Émas ${ }^{30}$ (Fig. 26)/

\section{Fólio 16v [10.09.1750]}

e Serièmas ${ }^{31}$ (Fig. 27), que saõ da mesma especie [sic], mas/mais pequenas. De toda se viu bastante, e se/ matou; porem a que tem mais gosto foi hũa/ Anta ${ }^{32}$ (Fig. 28) pelo muito, que se rezistio.

Começan-/do este rio em Largura de dois tiros de espin-/garda, dias antes de Chegar ao porto da/ Chambexuga, naõ passa em partes de ter/ tres braças. Os principaes rios, que neste/ se metem he do Anhanduy, e Anhandui-/mery, ambos pela parte esquerda, indo pa-/ra sima, como eu hia. Da barra do primeiro/ á Vacaria, saõ cinco dias de jornada. Cha-/maõ - Vacaria - hũas Campanhas, aonde an-/ da infinito gado, o qual dizem os Sertanis-/tas, que Lá o tem hido buscar, que fora a/hi posto pelos Castelhanos, que occuparaõ a-/quellas terras, que saõ as que ficaõ entre o/ Rio Grande, e o Rio Paraguai, aonde elles/tem infinitas Missoens./

A déz sel

$m a-/ /$

\section{Fólio 17r}

matou o primeiro Cervo 33 (Fig. 29), e como o modo de caçar es-/tes, e aos Viados hé taõ diferente do do Reino, naõ/ quero deichar de o explificar aqui. Estes comũ-/mente andaõ pelos campos, quando os cassado-/res os avistaõ, despem a camiza, e a poem pe-/la Cabeça, e se vaõ chegando desta sorte, fazen-/ do varias vizagens, com o que a cassa pára,/ e ás vezes vem reconhecer o que aquillo hé, e/ em chegando á pequena distancia, Ihe atiraõ/ ordinariamente com chumbo grosso, ou bastardo, pois de outra sorte naõ sabem. Para ma-/tarem as Émas, a buscaõ Levando hum ramo/diante da cara com o que deichaõ Chegar o caça-/dor de forma, que Ihe atira quaze á queima rô-/pa./

\footnotetext{
30 Ema (Rhea americana (Linnaeus, 1758).

31 Seriema (Cariama cristata (Linnaeus, 1766).

32 Anta (Tapirus terrestris (Linnaeus, 1758)).
}

33 Cervo (Blastocerus dichotomus (Illiger, 1815)). 


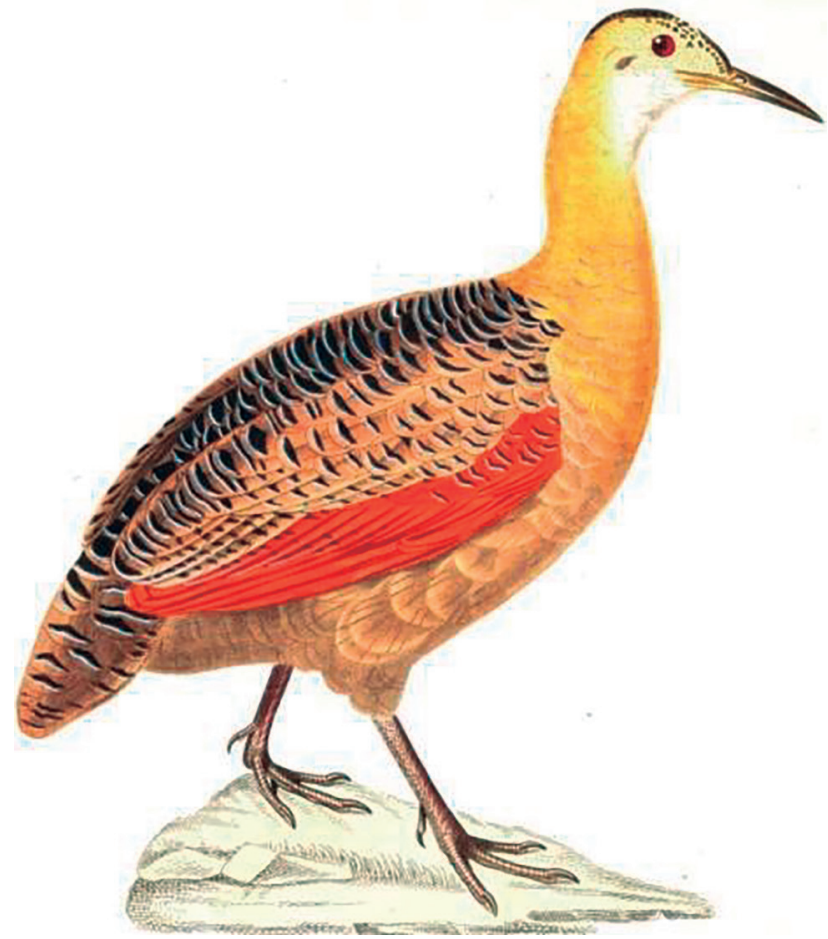

Figura 25. Perdiz.

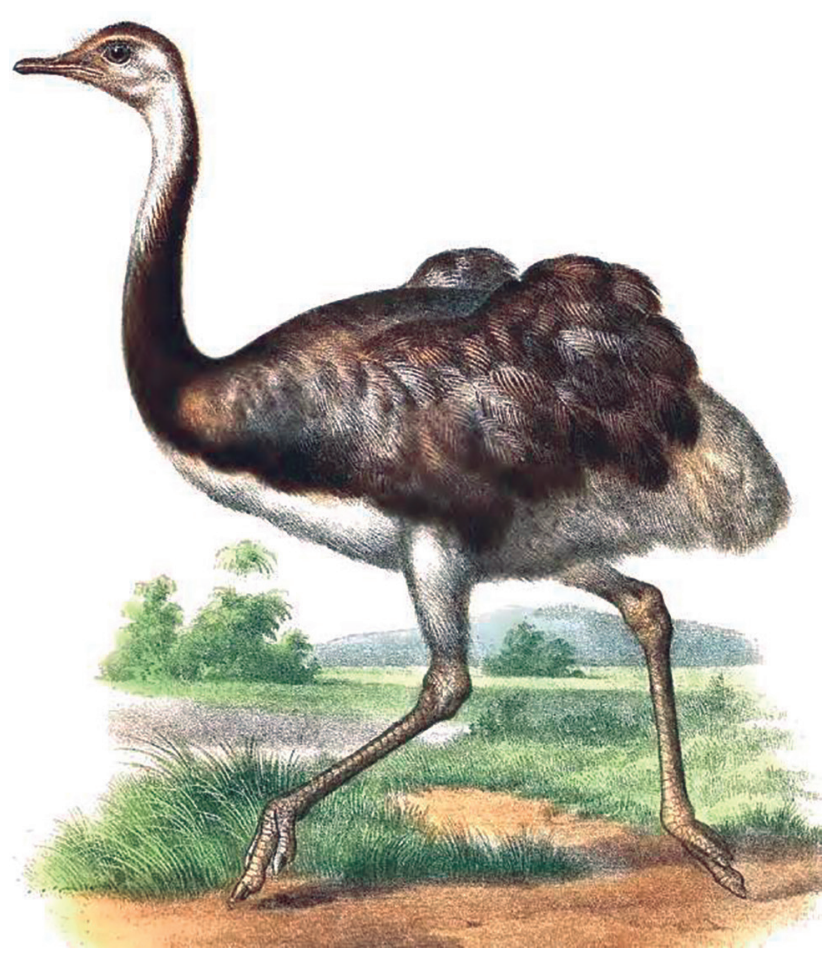

Figura 26. Ema.

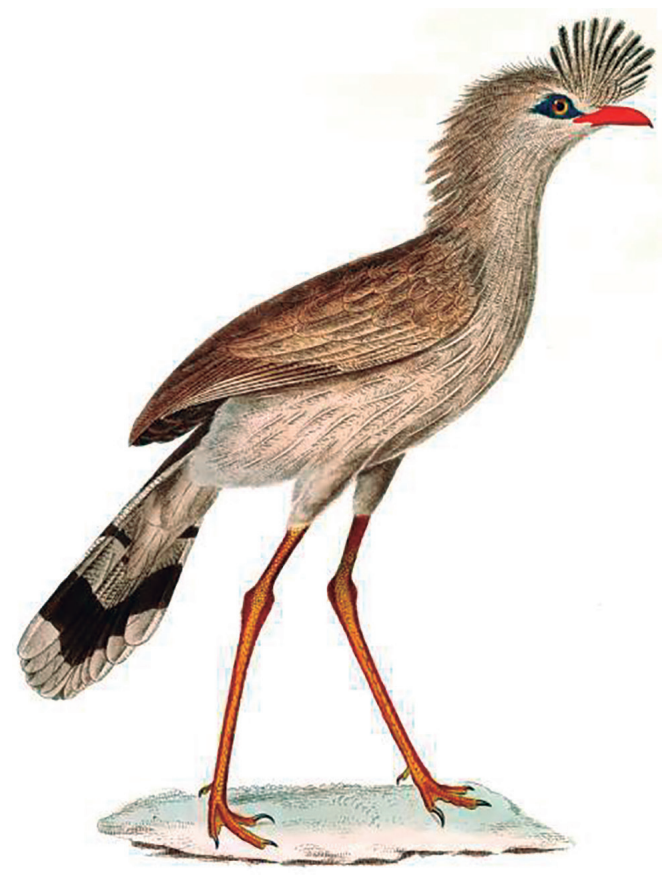

Figura 27. Seriema.

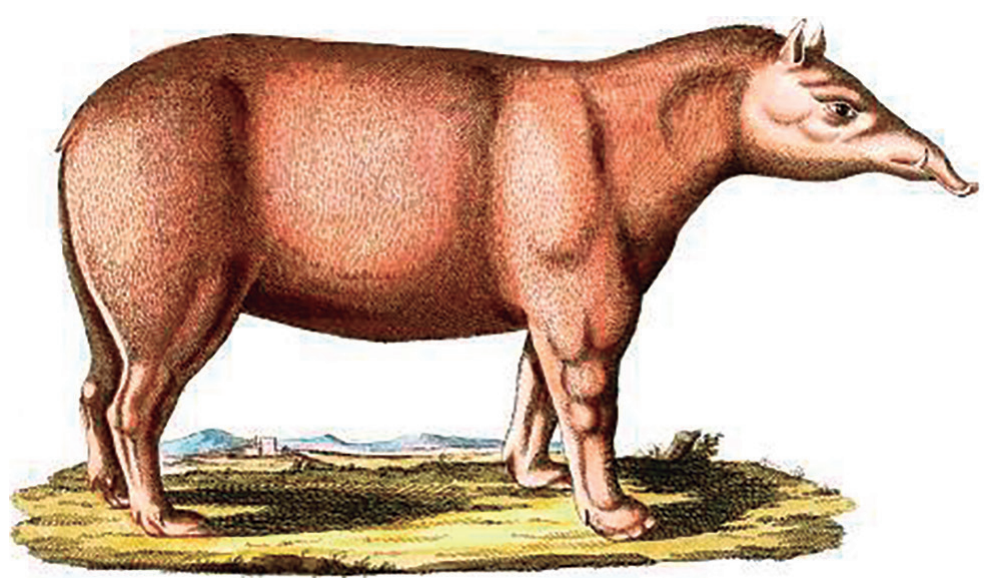

Figura 28. Anta.

Neste mesmo dia se matou o primei-/ro Jacaré a tres, ou quatro passos de distan-/cia da Canoa; que taõ pouco espantadissos/saõ. Este com ser pequeno, pelo que diceraõ,/ tinha seis palmos de comprido, uatro péz,/ Como Lagarto, mais grosso no Corpo, que hum/

homem//

\section{Fólio 17v [16.09-07.10.1750]}

homem pela coixa, rabo comprido á porpor-/ção do mais Corpo. A [pele] pela parte de sima/ feita em Cintas, como armas branças [sic], e taõ du-/ra, eu dando-Ihe á mão tente com hũa faca/ de ponta, 


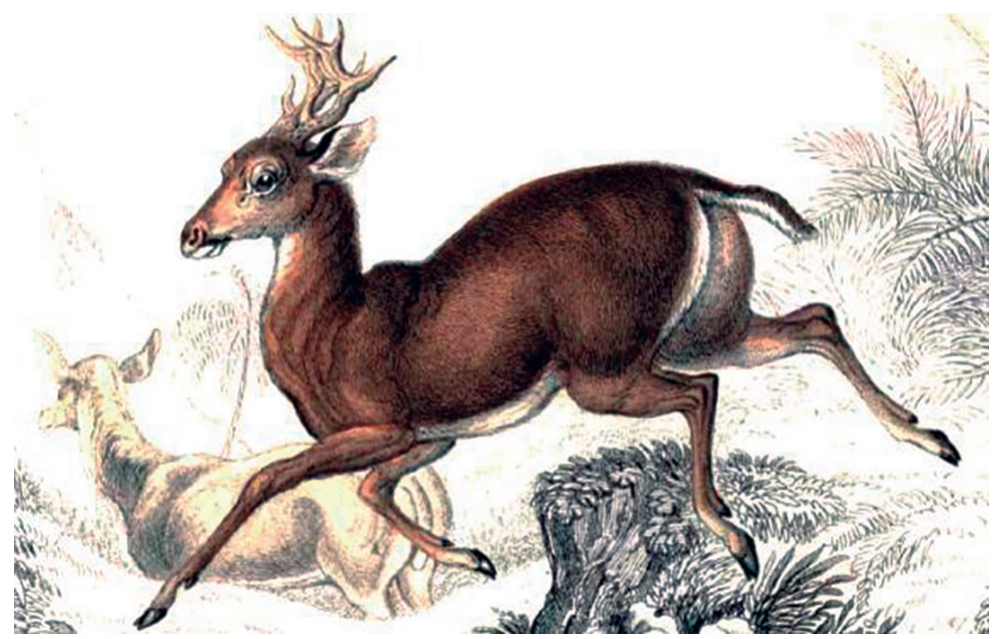

Figura 29. Cervo.

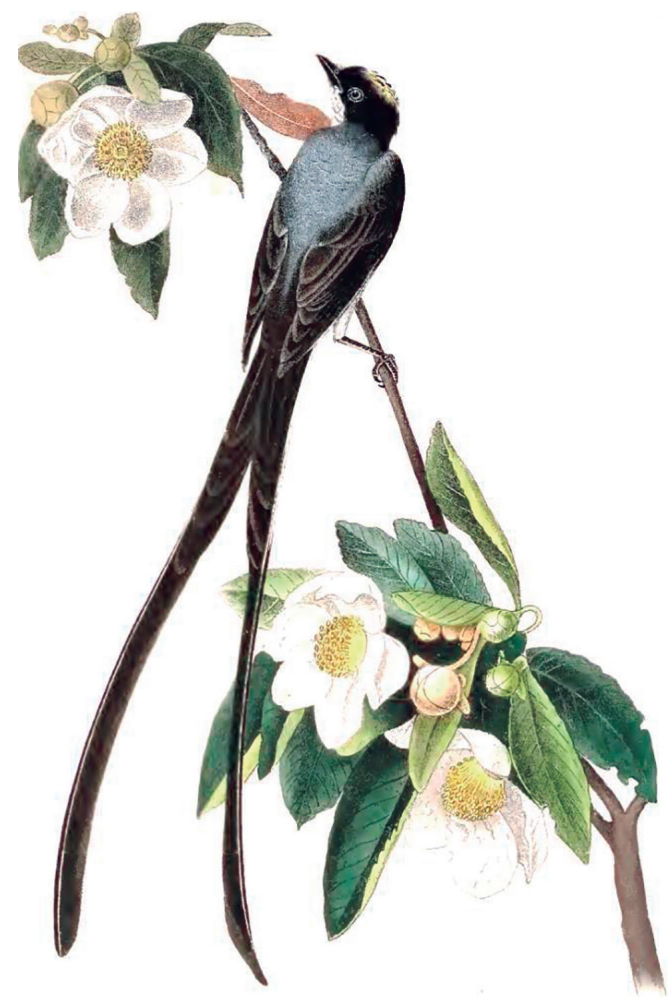

Figura 30. Tesoura.

apenas Ihe entrou grossura de duas/moedas de dez reis. A cabeça hé comprida, os/dentes de cão, e sem Lingoa ${ }^{34}$.

A 16 vi hũa/ pendencia de huns passarinhos do tamanho de/ Pintacilgos, a que chamaõ tizouras ${ }^{35}$ (Fig. 30) por terem/ o rabo do feitio deste instrumento, quando está a-/berto, com hum Gaviaõ, e sem embargo deste/ ser grande, e os passarinhos só dois, de tal sorte/ o perseguiram, que se vio obrigado a fugir, o q'/ me diceraõ ser por estes Ihe buscarem os olhos,/ aonde os picaõ./

A sette de Outubro passei hum/Jupia, que este Rio tem mais pequeno, e me-/nos perigoso, que o do Rio Grande, mas sem-/pre hé algũa couza. Como passei por/ junto a elle, tive todo o Lugar de observalo./

$\mathrm{Fa}-/ /$

\section{Fólio 18r [13.10.1750]}

Fazia a agoa a figura de hum covo, fundo, estrei-/to para baxo, a circunferencia da baze, que fica-/va para sima era maior, que a de hum gran-/de alguidar de amassar, e nesta figura remu-/inha a agoa, de forma, que segundo dizem os/ Piloutos, tem já socedido ali alagarem-se/ varias Canoas, puxando-as para o fundo a/ força d'agoa. Para se acautelarem disto Ihe/ deitaõ hũa corda, ou cadea pela proa, $e$ quã-/do vaõ chegando perto puxão por ella com/força as canoas da banda da terra até que te-/nhaõ Salvado o dito Jupiá, e algũas vezes as/seguraõ com outra corda pela poupa para/ que a Revessa, que ali hé grande as naõ bote/ sobre elle. A oito pela primera vez vi/ o Rio tinto de vermelho pela cauza, que já/ dice. A treze cheguei do Coraõ, em que o rio/ se despenha de hũa Lage abaixo, na altu-/ra de quarenta, ou Cincoenta palmos.-/ Os mais saltos deste Rio excepto o primeiro só tem/ a que basta para obrigar a que as cano-/

as/

\section{Fólio 18v [17-23.10.1750]}

se levem á Sirga, e á maõ por elles; e descarrega-/das; mas neste como bem se ve foi precizo con-/duzilas por terra. Antes de chegar a elle comi/ hũas frutinhas do mato, que em gosto, cor/ e figura se parecem

\footnotetext{
34 Na realidade 0 jacaré tem língua, mas ela é "colada" ou pregada na parte inferior da boca, o que faz com que 0 animal tenha que comer com a boca aberta e fazer movimentos com o corpo para empurrar a comida goela abaixo.

35 Tesoura - Muscivora tyrannus (Linnaeus, 1766).
} 


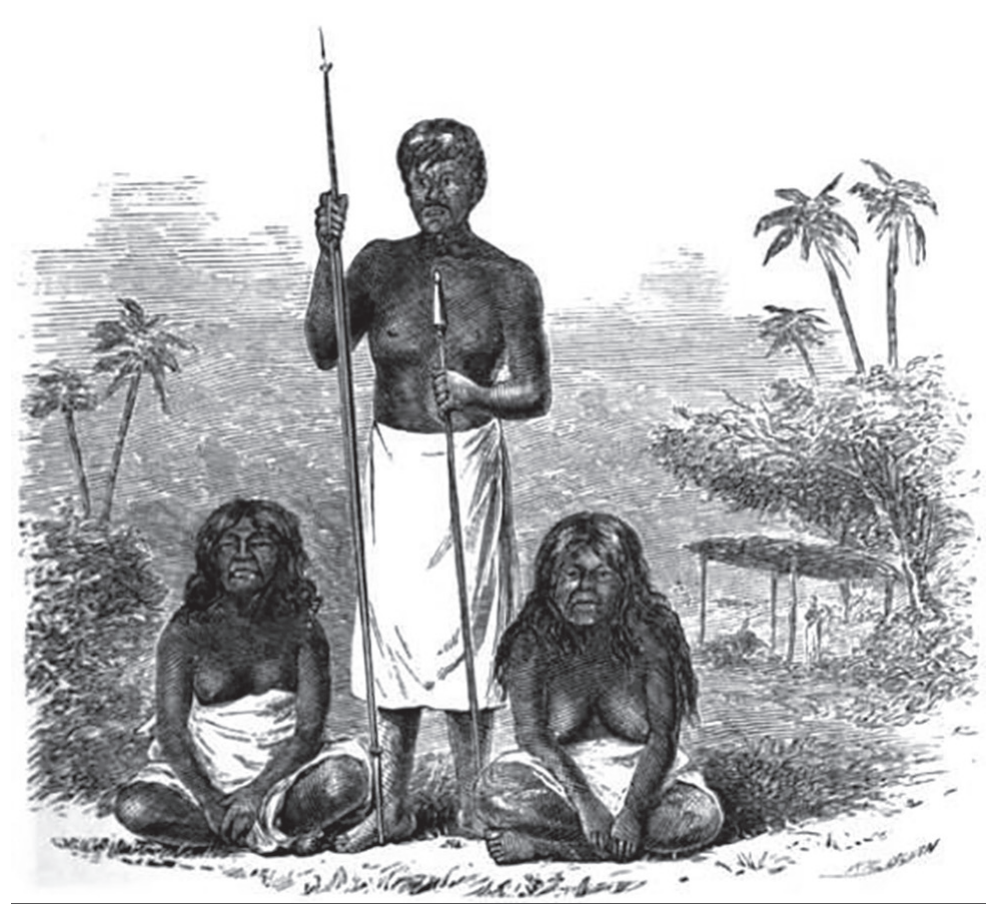

Figura 32. Índios Payaguá (Washburn, 1871: 43).

Figura 31. Lobo ou Guará.

muito com as nossas Sere-/jas. A 17 se matou hum Lobo ${ }^{36}$ (Fig. 31), que hera do/ tamanho de hum cão ordinario. O pello averme-/lhado, a cabeça mais curta, a boca menos rasga-/da e os dentes mais pequenos, que os nossos cus-/tumaõ ter, e taõbem parecem naõ serem taõ/sagazes; porque o mataraõ á queima roupa/parado de hum perdigueiro, e quieto. Da-/qui para diante dá o Rio infinitas voltas,/ muito curtas, e algũas inteiramente oppos-/tas hũas ás outras.

A vinte e tres pou-/co adiante do Salto do formigueiro me esta-/va esperando o Capitaõ mór de Cuiabá, o/ qual havia vindo com as canoas de guerra/ escoltando as de comercio por cauza do Gen-/tio Pouagoa $^{37}$ [sic] (Fig. 32), e ainda que aquellas naõ/

costu-//

\section{Fólio 19r [25-28.10.1750]}

costumão passer do Tacoary [Taquari], elle se adiantou/ ate camapuan para vir comprimentar-me,/ de donde por terra veio buscar-me até onde/ digo.

A vinte e cinco passei o ribeirão verme-/Iho, em que já tenho falado, que me ficou á/ direita, e tem hũa braça de Largura, ou pou-/co mais, e naõ chega a Cubrir meia perna,/ sem embargo do que tem os effeitos, que con-/tei. Dali para sima há agoa sumamente cris-/talina, e a melhor, que em toda a jornada en-/contrei.

A vinte e oito cheguei ao porto de Sam-/bexuga, cujo nome Ihe dá hũa alagoa, que fica/ perto, que as tem excelentes, couza rarissima no/ Brazil. Aqui há huns ranchos cobertos de/ palha, aonde se meteraõ as cargas das Canoas./Tanto neste Cítio, como por todo o rio Pardo/ hé distrito de Gentio Caiapózs, o qual tem/feito muitos insultos; por cuja cauza man-/dava pôr sempre hũa guarda para a/

par-//

36 Lobo ou guará - (Chryscyon brachiurus (Illiger, 1815).

37 Os Payaguá eram um grupo indígena, atualmente considerado extinto, que habitava a região do Alto Rio Paraguai. Também eram chamados de canoeiros. Eram um subgrupo dos Guaikuru.

380 termo Kayapó é um exônimo que data do início do século XIX, tendo sido criado por grupos indígenas vizinhos desta etnia. Significa "homens semelhantes aos macacos" e está, provavelmente, ligado a certos rituais do grupo, nos quais os homens dançam usando máscaras de macaco. 0 endônimo dos chamados kayapó é mebengokre, que significa, literalmente, "homens do buraco (ou poço) d'água". Os Kaiapó se dividem nos subgrupos: Kayapó-aucre, Kayapó-cararaô, Kayapó-cocraimoro, Kayapó-cubem-cram-quem, Kayapó-gorotire, Kayapó-mecranoti, Kayapó-metuctire, Kayapó-pau-d’arco, Kayapó-quicretum e Kayapó-xicrim. No passado, eram também chamados de coroados, e os de Mato Grosso, coroás. João Antonio Cabral Camello informou, em 1727, ao Pe. Diogo Soares o seguinte (cf. Varnhagen, 1842: 491): "Por todo este grande rio costumam andar os Cayapós; uma legua pouco mais das suas cabeceiras ha uma varge, e n'ella uma lagoa, á que chamam a Sambixuga: n'esta varge se desembarca, e tirando por terra as canôas, se põem em umas carretas de quatro rodas pequenas, de que tiram vinte e mais negros, distancia de legua e meia, até as pôrem no pequeno riacho de Camapoam, uma legua pouco mais ou menos do seu nascimento, em sitio em que estão duas roças povoadas; as cargas vão á cabeça dos negros, e se gastam n'esta passagem quinze ou vinte dias; é porém precisa toda a vigilância n'ella, porque os Cayapós não perdem toda a boa occasiaõ que se lhe offerece: como com effeito experimentaram uns de $S$. Paulo, que foram na mesma tropa, por nomes Luiz Rodrigues Villares, e Gregorio de Crasto, que no meio da fileira dos negros que Ihe conduziam as cargas, e seriam sessenta ou mais, Ihes ataram tres ou quarro, retirando-se tão velozmente, que quando os mais levaram as espingardas à cara, já os não viram". 


\section{Fólio 19v}

parte da Campanha, cubrindo todo o acampamento: e nesse porto foi precizo deichar ou-/tra para della acompanharem sempre solda-/dos a condução das cargas, e canoas até cama-/puan, a qual se faz em carros, e de noite em re-/zão da violencia do Sol, que se comessa a Sentir/ dali por diante mais rigorozo. No dia se-/guinte me puz a caminho para o dito Sitio de/Camapuan, e sem embargo de ser esta distancia/ de duas Legoas boas as fiz a pé, com toda/ a minha Commitiva por naõ haver mais que/ dois Cavalos na fazenda, e uns pouco Capa-/zes./

Fica o dito Sitio, ou fazenda de Camapuan/ á borda de hum pequeno rio, do qual toma o no-/me, como ali naõ há outro morador, tem/ elle toda a largura, que querem os seus do-/nos, que saõ quatro em hũa sociedade pa-/ra se utilizarem dos Lucros; que saõ gran-/des nas carreaçoens das Canoas, e fazendas,/ e no mantimento, que vendem aos passagei-/

ros//

\section{Fólio 20r}

passageiros. Tem sempre grande abundancia/ de milho, farinha do mesmo, feijaõ, arróz, por-/cos, e vacas, das quaes se naõ sabe já o nu-/mero pela Largueza dos pastos, e se enten-/de passarão de seis centas cabeças: por esta/ Conveniencia vive ali hum dos socios com al-/guns Camaradas brancos, $e$ bastantes pretos/ expostos aos ataques do Caipó [sic], e sem missa, nem/ quem o conforte em cazo de perigo, ao mesmo tem-/po que a distancia hé taõ grande para qu-/alquer dos povoados./

Tem aquelle Citio Cazas/ de sobrado muito sufficientes para a parte, em que estaõ, pois nellas me acommodei com/ todos os Officiaes, e Familia, estaõ dentro de/ hum pateo fexado, em que se pode tourear. Alem destas altas em que eu fquei tem ou-/tras mais no mesmo pateo, e juntamente ca-/pella com mais asseio do que ali se podia es-/perar. Neste citio me despi pela primeira véz, o que até entaõ naõ tinha feito desde o/

prin-//

\section{Fólio 20v}

principio da viagem, excepto para mudar/ de roupa: tanto a fim de estar mais prompto/ para as madrugadas, que sempre eraõ pelas/tres horas da manhañ, principalmente depois/ que sahi do Teéte; porque naquelle rio mel Levantava mais tarde algũa couza em rezaõ/ de naõ poder sahir sedo por cauza das nevoas, / que saõ de todos os dias, e em alguns se extende/ até muito tade, e por cauza das caxoeiras se/ naõ pode navegar aquelle rio com ellas. An-/tes me vi hũa vez obrigado a fazer alto até/ que aclarasse hũa serraçaõ, que trouce hũa/trovoada; pois hé precizo, que esteja bem cla-/ro para os piloutos conhecerem as pedras,/ que estaõ debaixo d'agoa. Taõbem tirava da-/quella pratica a conveniencia de me resguar-/dar melhor dos mosquitos, os quaes perseguem/muito em todo o tempo da viagem. Comi-/

Até ali os/ experimentei de tres castas; huns muito peque-/nos a que chamaõ polvora pela grande chaõ//

\section{Fólio 21r}

comichão, que fazem: outros Burrachudos,/ que saõ maiores, e barrigudos, que Logo que/ mordem tiraõ sangue, cuja nodoa fica por/muitos dias, e com dor; os terceiros, que mais pro-/priamente saõ moscas pequenas me persegui-/ram mais, quando sahia ao campo á cassa naõ/ picam. Mas buscaõ os olhos ${ }^{39}$ com tal prolixida-/de, que sempre andava na diligencia de os ti-/rar delles, o que algũas vezes mos fez agravar./

Alem destas sevandi-/jas houveraõ [sic] partes, em que nos enchemos de/ Carrapatos, os quaes se ferravaõ no corpo, e fa-/ziaõ bortueja, e comichão dezesperada. Para/os tirar foi precizo Lavar-me, ou para melhor/dizer, sujar me com agoa de tabaco de fumo,/ que he o que os faz cahir. Tambem pelo rio/ Pardo encontramos hũas formigas que a-/onde chegaõ roem tudo. A hum dos Missi-/onarios em hũa noite lhe deixarão a roupa/ incapaz de se vestir, e outras pessoas mais per-/deraõ varios trastes dos seus vestidos./ 
Fólio $21 v$

Os dias, que aqui estive parado, me dever-/ti taõbem com hir ás perdizes, quando a/ chuva me dava Lugar; ainda que ali há/ menos sempre vinhaõ algũas para ca-/za; porem o tempo, como já dice, me dava/ pouco Logar; porque todos os dias ou mais/ ou menos sempre havia trovoadas, e como/ estas se armavaõ, quando hia chegando ao/meio dia, e embaraçavaõ taõbem poder to-/mar o Sol á minha vontade. Hum dia ain-/da que com grande deficuldade, por se estar es-/condendo de quando em quando me pareceu/ achar altura de dezanove graos, e mais. Taõ-/bem comecei a experimentar naquelle Sitio peores agoas; porque alem de trazerem sem-/pre algũa area, aí continuas trovoadas/faziaõ ainda mais turvas. Sem embar-/go do muito gado, que há naquella fazen-/da, como a conveniencia dos donos hé que [?]/os passageiros se demorem, nunca hé muito/ o que tem manso, e capáz de andar com/

\section{Fólio 22r [20.11.1750]}

os Carros, os quaes taõbem ordinariamente naõ/ passaõ de dois os que tem cada hũa das fazen-/ das, e ainda que com o avizo, que eu lhe tinha/ feito, estavaõ mais algum promptos, nunca/ pude dezembaraçarme antes de vinte de No-/vembro, pelas minhas Canoas, e cargas, que/ houve, que passar, e pela pouca força dos bo-/is, que sem embargo de serem formozos, saõ/necessarias tres, e quatro juntas para o tra-/balho, que faz huma dos nossos, o qual estes naõ/ podem fazer, senaõ de noite, ou com muito pou-/co Sol.

Finalmente naquelle dia me puz á/ Caminho a pé com toda a gente, e me fui em-/barcar dali meia Legoa no rio Camapuan,/ porque ainda que este passa ao pé das cazas,//aonde eu estava, Leva ainda naquelle Lo-/gar taõ pouca agoa, que o caminho, que eu/ fiz por terra em pouco mais de meia ho-/ra, Leva ás canoas pelo rio alguas vezes dois e tres dias com grande trabalho, tanto/

pela/l

\section{Fólio 22v}

pela falta de agoa, como pelas muitas voltas,/ e embaraços de paos./

Aonde eu me embarquei,/se Ihe junta outro rio da mesma Largura/sem embargo do que me pareceu naõ exce-/der a de cinco braças; como passa por entre/ matos muito espessos, e estes na America tem/

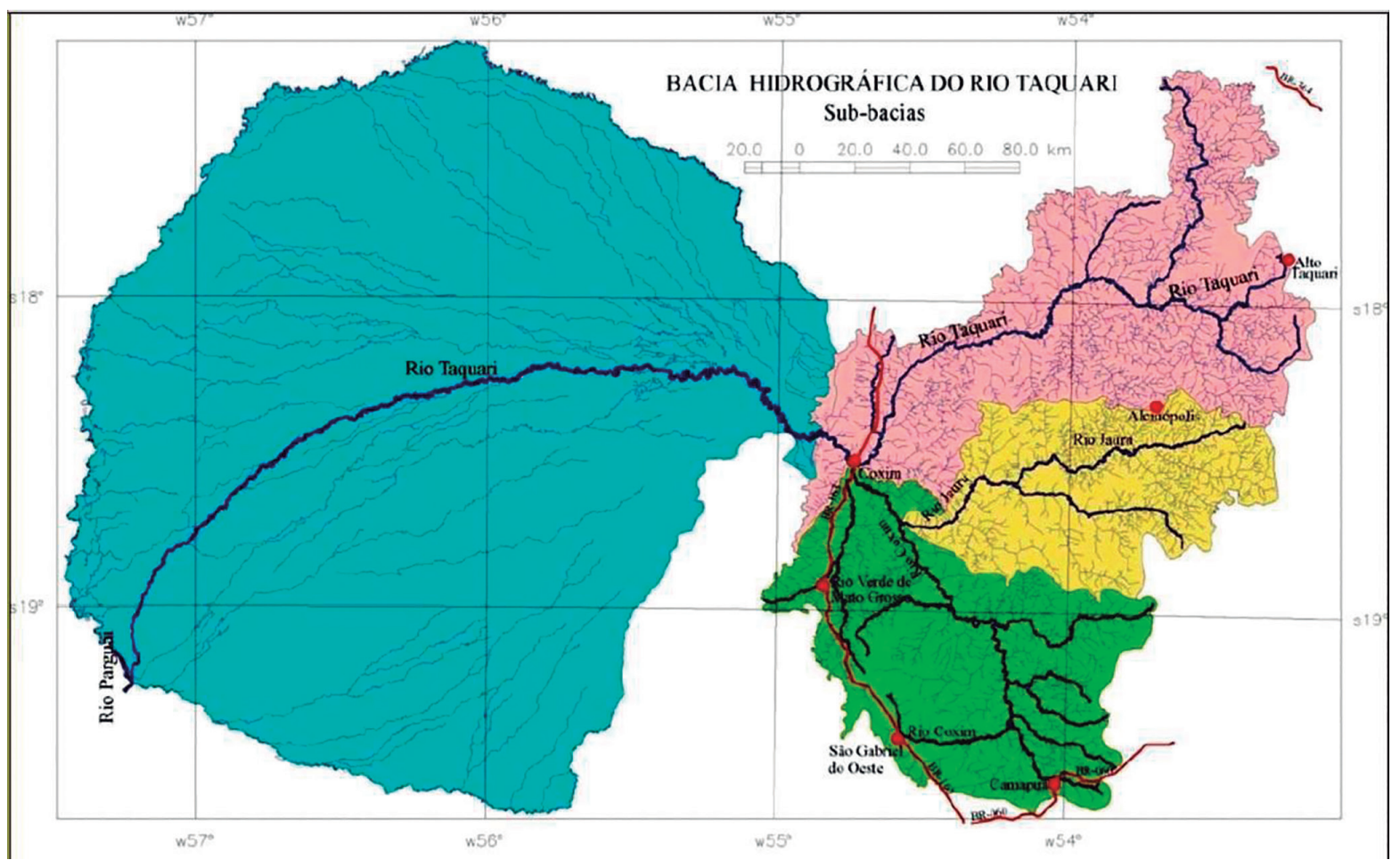

Figura 33. Rios Coxim e Taquari. 
as raizes á flor da terra, as cheias escarnã-/do estas derrubaõ todos os annos quantida-/des de paõs [sic]. os quaes pela pouca Largura do/ rio atravessaõ de hũa parte á outra de/Sorte, que todas as canoas, que por elle pas-/saõ, he necessario cortarem muitos para a-/brir caminho, e como aquelle rio hé taõ peque-/ no com qualquer agoa enche muito, e com a/mesma facilidade torna a vazar, pelo q'/ nunca hũa tropao acha na mesma igu-/aldade, que a outra, e pela mesma razaõ/se naõ aproveita hũa dos paos, que a que/ passou diante havia cortado. Eu passan-/do agora, verbi gratia posso rolar por bai-/

$x O / /$

\section{Fólio 23r}

baixo de hum paõ [sic], que está atravessado de bar-/ranco a barranco: enche mais o rio, e já as/canoas, que neste estado navegaõ lhes faz/ embaraço o mesmo pao./

Este rio naveguei pa-/ra baixo, e como a sua correnteza hé violenta,/ e elle tem os embaraços, que expus, se serviaõ/ os remeiros de varas naõ para empurrar/ as canoas para diante, mas para as hi-/rem tendo maõ a fim que ellas naõ ganhas-/sem força com o impulso da mesma corren-/te, e se virassem, ou quebrassem, batendo com/ o mesmo impulso nos ditos paos. Alem des-/te perigo correm outro os navegantes, e vem/ a ser que muitos daquelles paos estaõ como/ já dice atravessados em altura, que as ca-/noas podem passar por baixo; quando is-/to hé escaçamente, Ihe chamaõ aos taes pa-/os razouras; por que é quazi razaõ as ca-/noas na passagem, nestes hé necessário grã-/de cuidado; por que naõ soceda apanharem/

algum//

\section{Fólio 23v}

algum entre si, e a borda da canoa. Por fal-/ta delle hiaõ socedendo algũas desgraças por/ se naõ abaixarem a tempo, sendo precizo/a alguns Lançarem-se ao rio para escapar/de morrerem arrebentados. Alem disto se/vai sempre passando por baixo de ramos, q'/ lançaõ os paos, que estaõ á borda do rio, e/ rossando por elles traz dentro á canoa/ quanta porcaria, e bixaria elles tem sobre/si. Isto me familiarizou tanto com as ara-/nhas, que já me naõ cansava com as sacudir/de mim; por que a todo instante estavã̃ ca-/indo. Taõbem pelos mesmos ramos estavaõ/varios enxames de besperas ${ }^{40}$ muito grandes,/a que por estas terras chamaõ maribondos,/ que mordem dezesperadamente./

Neste rio/ me servirão muito as canoas de montaria,/ as quaes mandava diante com gente e ma-/ chados para me hirem cortando os paos, e/ dezembaraçando o caminho; pela minha/

conta entendo//

\section{Fólio 24r [23.11.1750]}

entendo se cortarão mais de oitenta.

A vinte/ e tres pela menhaã entrei no Cochiin [Coxim] (Fig. 33), que/ taõbem naveguei para baixo. Este hé já/ mais largo, pelo que se naõ experimentaõ/ nelle os incomodos do antecedente; porem no/ primeiro dia hé o perigo muito maior. Tem/ de muitos annos varios paos debaixo d'agoa;/ a corrente hé violenta com exceço; leva-se/ a remo por se navegar pelo meio delle, aon-/de he fundo. As voltas são curtas, de sor-/te que quando se concluem os paos, naõ hé tem-/po de tomarem os piloutos partido, e se rezol-/vem por que parte hão de meter a canoa./ Para acautelar este perigo mandava hir di-/ante as canoas de montaria, que como mais/ Ligeiras naõ tem tanto, estas avizavaõ dos/ paos, e da parte por que se haviaõ de tomar,/ e a mesma palavra se hia passando de canoa/ em canoa em altos gritos, o que fazia hum/arruido continuado com algum orror.

Alguns//

\section{Fólio 24v}

Alguns destes passos eraõ mais deficulto-/zos por cauza do que ficava entaõ nelles al-/gũa das ditas canoa de montaria para os/mostrar. 
Alem do perigo dos paos tem este/ rio vinte e duas caxoeiras, quazi todas deficulto-/zas, cinco principalmente, em que hé precizo des-/carregarem-se as canoas para as poderem pas-/sar com grande trabalho: em partes corre o rio/ com hua violencia extraordinaria incanada/ por entre paredoens altissimos cortados a pru-/mo de sorte que os primeiros Sertanistas se naõ/ atreviaõ a subir este rio, $e$ o fizeraõ a primei-/ra vez, quando se retirou do Cuiabá Rodrigo Cezar ${ }^{41}$ : servem-se para isto de puxarem as/ Canoas por cordas marchando, e firmando-se/ em pedras, que estaõ ao Longo do mesmo rio en-/ costadas aos paredoens.

Se os Gentios nossos/ inimigos soubessem discursar, poucos, que se/ pozessem em sima daquelles paredoens ro-l

lando//

\section{Fólio 25r [28.11.1750]}

rolando pedras para baixo era o que basta-/va para naõ poder passar canoa, que se naõ/ a fundisse; porem a sua brutalidade nos pre-/zerva deste risco; ao que os ajudaria muito/ a pouca Largura, que naquelles Lugares le-/va o rio, que naõ passará de quatro ou cinco/braças. Nas mais partes me pareceu seria/ sempre de quinze para sima.

A vinte e oito/ de tarde entrei no Tacoary (Fig. 33), acabando de passar/ a ultima Cachoeira, que o hé taõbem de todo o ca-/minho. Hé este rio bastantemente Largo, e/ como dá muitas voltas parece aos que o na-/vegam, que está sempre em bahias fexadas./ Quando leva pouca agoa deixa varias pra-/ias descubertas, as quaes se enchem de cassa,/ principalmente Patos de extraordinaria grã-/deza, e outros mais pequenos, a que chamaõ Marecos. Há taõbem pellos matos muita/ Aracoam ${ }^{42}$ (Fig. 34), Jacúz $z^{43}$ (Fig. 35), e Jacotingas ${ }^{44}$ (Fig. 36); passaõ de/ bom gosto, saudaveis de modo, que se daõ aos/

doentes//

\section{Fólio 25v [29.11.1750]}

doentes principalmente as Aracoans; que sen-/do destes os mais pequenos, sempre tem o ta-/manho das nossas Frangas. Há outros, a que/ chamaõ Mutins ${ }^{45}$ (Fig. 37) [sic], do tamanho dos nossos pe-/runs novos, muito airozos, e bem feitos, e de/ bom gosto. A caça de pello taõbem hé in-/finita: muito porco brabo ${ }^{46}$ (Fig. 38), muito viado, e ca-/pivaras.

Como deste rio para diante hé/ o perigo, de se encontar o gentio Cavaleiro ${ }^{47}$, el Payagoá, costumaõ as tropas esperar nelle hũ-/as pelas outras pela facilidade de se mante-/rem com a Cassa, e dali vaõ juntas em con-/serva das canoas de guerra, que vaõ sem-/pre do Cuiabá escoltando as que sahem, e/ para conduzir as que vem. Quando eu che-guei àquelle rio, Levava elle já bastante a-/goa, e por isso naõ achei tanta cassa, mas/ sempre vi algua de todas as especies, que te-/nho dito.

A 29 cheguei aonde estavam ar-/

ranchados//

\section{Fólio 26r}

arranchados, os que haviaõ vindo nas canoas de/ guerra do Cuiabá, á diligencia, que assima di-/ce, as quaes costumaõ esperar nequelle Lugar,/ ou nas suas vezinhanças por ser aonde se cor-/taõ varas para navegarem as canoas do Pa-/ragoay mirim para diante, no qual se comenda/subir. Constava tal armada sutil de cin-/co Canoas, a saber duas propriamente de guer-/ra por virem dezembaracádas [sic], e sem cargas,/ a sua guarnição constava de cinco, ou seis ho-/mens cada hũa, e vinte e quatro espingardas,/

41 Rodrigo César de Meneses foi um administrador colonial português que exerceu o cargo de Governador e de Capitão-General da Capitania de São Paulo entre 1721 e 1728 , e da Capitania-Geral do Reino de Angola entre 1732 e 1738, tendo sido antecedido por Paulo Caetano de Albuquerque e sucedido por João Joaquim Jacques de Magalhães. Foi também responsável pela fundação da Vila de Cuiabá, em 1726, após a descoberta de ouro na região.

42 Aracuã - Ortalis canicollis Wagler, 1830.

43 Jacu - Penelope ochrogaster Pelzeln, 1870.

44 Jacutinga - Aburriajacutinga jacutinga (Spix, 1815)

45 Mutum ou mutum-pinima - Crax fasciolata Spix, 1825).

46 Referência aos caititus (Tayassu tajacu (Linnaeus, 1758)) ou aos queixadas (Tayassu pecari (Link, 1795)).

47 Os espanhóis colonizadores chamaram de Mbayá (termo provavelmente de origem Tupi) aos Guaikuru (nome também de origem Tupi), dos quais descendem os Kadiwéu. Com origem no lado ocidental do rio Paraguai, parte dos Mbayá atravessou, no século XVII, para a banda oriental. Com a pressão das frentes colonizadoras, deslocaram-se mais para o norte e os que ainda não tinham migrado para leste do rio o fizeram no final do século XVIII. Nessa época o seu território se estendia das serras que separam os rios Paraná e Paraguai até mais além da latitude de $18^{\circ}$ sul. 0 s Kadiwéu, que a literatura histórica uma vez chamou de "os índios cavaleiros", por sua condição de possuidores de um vasto rebanho equino e sua admirável destreza na montaria, vivem hoje localizados no Estado do Mato Grosso do Sul, em terras parte incidentes no Pantanal matogrossense. Sobre os índios Guaikuru, ver Camponez ([1766] 1865) e Prado ([1793] 1839). 


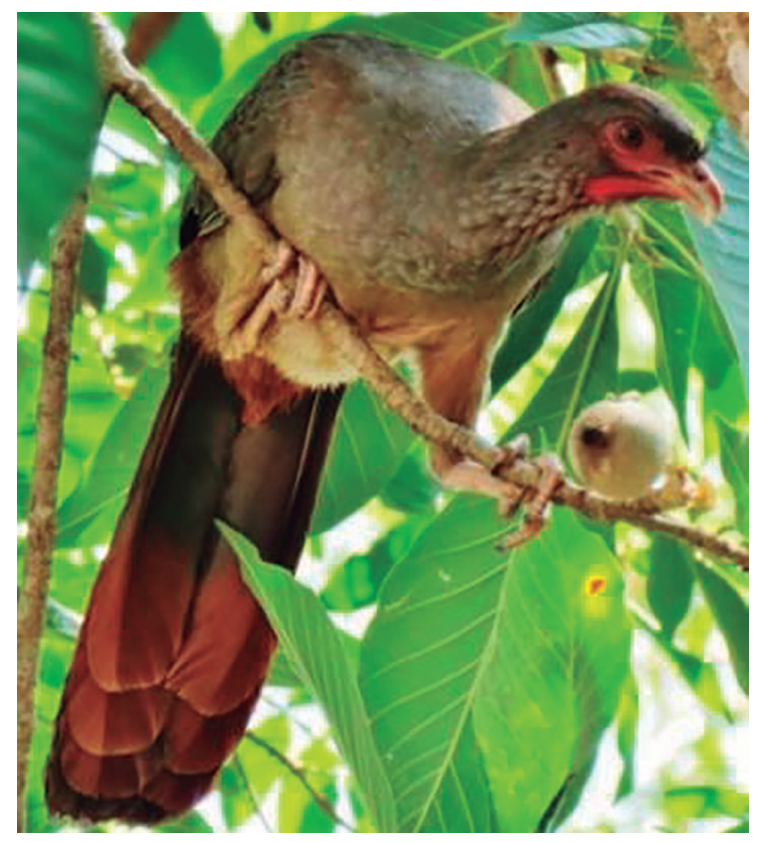

Figura 34. Araquã.

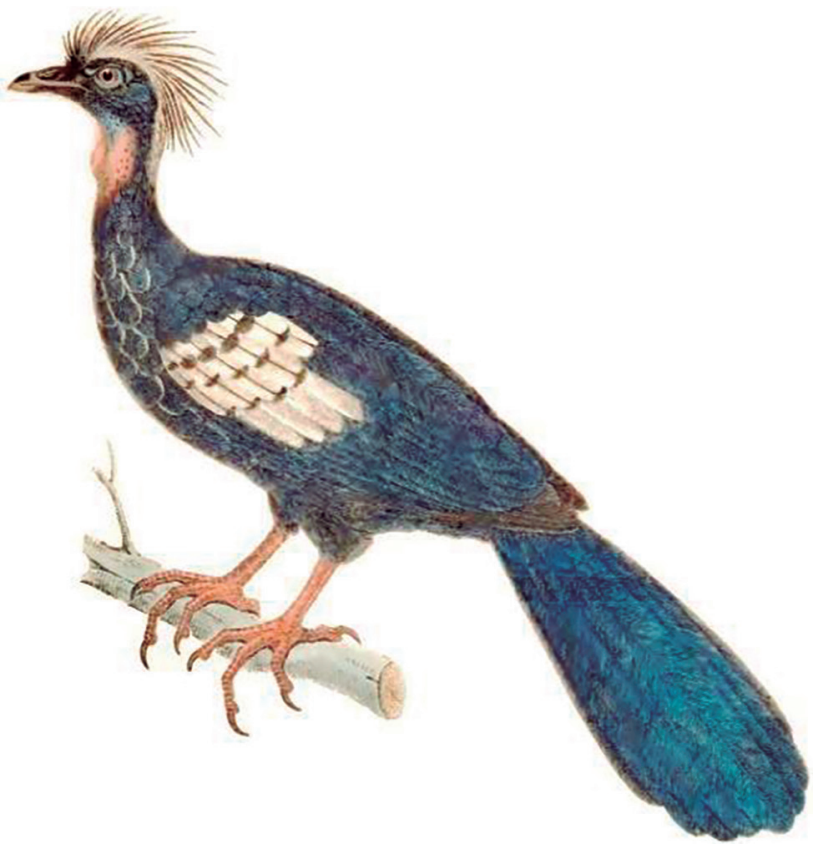

Figura 36. Jacutinga.

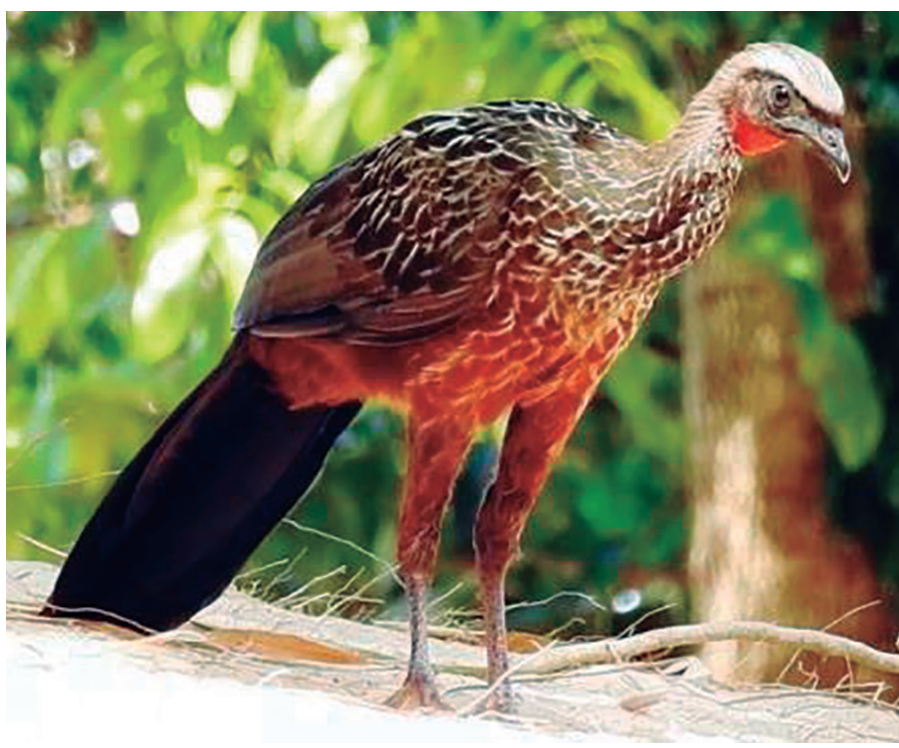

Figura 35. Jacu.

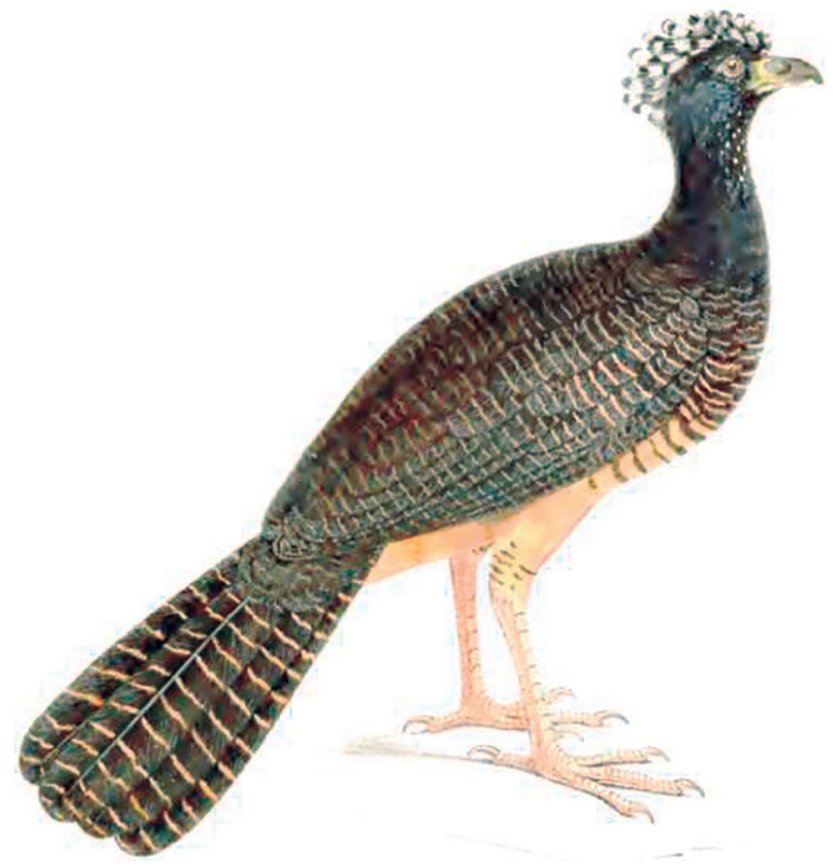

Figura 37. Mutum-pinima.

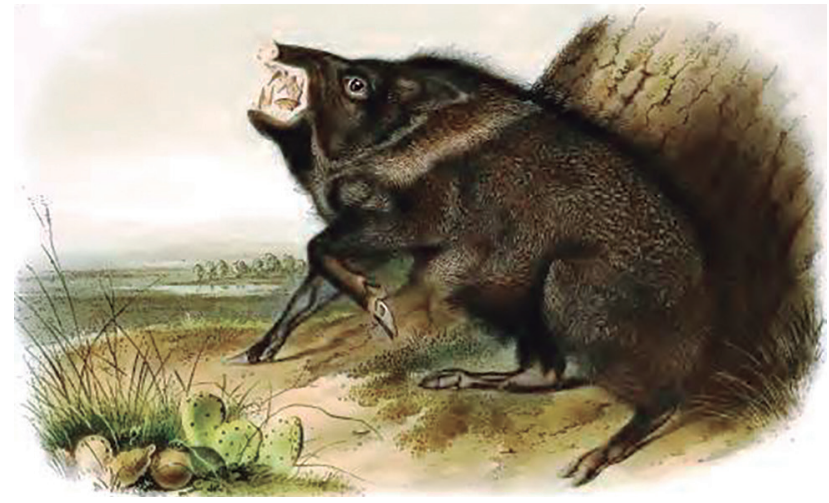

Figura 38. Caititu. 
atacadas com bastardos, ou perdigotos ${ }^{48}$, as ou-/tras duas Levavaõ taõbem alguns homens fó-/ra os remeiros, e alguas armas, ejuntamen-/te mantimentos, com o que naõ ficaõ taõ ca-/pazes de se baterem. A quinta hera de mon-/taria para espiar e descubrir os gentios, e/ dar parte. Fiaõ-se estes soldados unica-/ mente no fogo de sorte que nem espada le-/vavaõ. Estas canoas, excepto a montaria/se custumaõ dividir pela vamguarda, e retagu-/

arda//

\section{Fólio 26v [02.12.1750]}

e retaguarda, e se a tropa que acompanhaõ, hé mui-/to grande se poem alguas taõbem pelo Centro pa-/ ra acudirem com promptidaõ á parte atacada./ A dois de Dezembro me fui arranchar em hum/ mato, que estava cheio de palmitos, havendo mar-/chado naquelle dia e no antecedente com maior/Cautella por me hir avezinhando ao destricto,/ em que se custuma encontrar gentio. Hé o pal-/mito hũa arvore, de cujo tronco se tira hũa espe-/cie de nabo, ou raiz branda, e gostoza, a qual/se come guizada de varias maneiras, e ainda/ crua há algua, que tem o gosto de casta-/nha verde. Naõ somente ali mas em vari-/ as partes achei aquella especie de hortaliça [sic] pe-/lo caminho, que naõ somente nelle, mas ainda/ nos povoados tem estimação./

Naquella para-/gem me demorei alguns dias á esperar pelo Juiz/ de Fóra de Mato Grosso, tanto por amor delle/ pelo muito que tinha trabalhado na minha jor-/nada, como em razaõ de trazer na minha/

com-//

\section{Fólio 27r}

companhia muitas cargas de muniçoens de El-/Rey, minhas, e da cometiva, as quaes trazia/ elle com sigo. Desta demora me servi para/fazer exercicio aos Soldados de como se ha-/viaõ haver sendo atacados. Trés saõ/as Naçoens, que custumaõ perseguir aos vi-/andantes deste Caminho; á primeira hé dos/Caiapós. Saõ forcozos [sic], e Ligeiros: Uzaõ por/ armas de arco, e flexa, e de porretes. A pri-/meira bem conhecida hé, e por isso me naõ can-/ço em explica-la; a segunda saõ huns paos/do tamanho de hum Covado pouco mais ou/menos, de hũa parte redondos, por onde lhe/ pegaõ e pela outra espalmados, como as páz/dos Remos; enfeita-nos [sic] cobrindo-os com seus/tecidos feitos de cascas de arvores de varias co-/res á imitação de esteiras; porem muito a-/justados, e unidos aos paos (Fig. 39). O seu modo de/ peleijar hé atreiçoadamente. Tomando sen-/tido onde algũa tropa se arrancha, e pare-/cendo-Ihe, que tem partido a vem atacar,/

quan-//

\section{Fólio 27v}

quando a achaõ descuidada; porem se a tropa/ tem algum poder, se naõ rezolvem a isso. $O$ ma-/is commum hé esperar os que sahem ao Cam-/po a cassar; encondendo-se de modo, que não hé/ facil vellos por se pintarem de modo, que ficaõ/ da côr do mesmo mato, e derrepente darem sobre/ os que vaõ passando, atirando-Ihe primeiro com/ as frexas; e depois quebrando-lhe a cabeça de perto com os porretes, o que feito fojem Logo, Lar-/gando a arma com que fizeraõ a morte. Con-/tra estes basta hũa pouca de Cautela nos ran-/chos, e taõbem que naõ saião menos de tres, ou/ quatro a cassar, e que estes se recolhaõ juntos; pois na retirada hé que elles custumaõ mais/dar os seus assaltos. Do Tacuari para dian-/te já se naõ encontrão, nem daõ cuidado. A segunda hé dos Cavaleiros, a que chamaõ/assim por andarem sempre a cavalo. Vivem/ a borda do Rio Paraguai da parte do poente, e/ vizinhaõ com as povoaçoens dos Castelhanos, que/ experimentaõ delles alguns insultos, e se extendem/ pela mesma borda do rio até às vizinhanças/

\section{Fólio 28r}

do Caminho, que eu truce. Pelo tempo que os/rios estaõ baços, vem buscar o Tacuari, e atraves-/sando-o vaõ fazer guerra ao Gentio das var-/geas assim chamado, por terem nellas as suas/ povoaçoens, das quaes cativaõ muitos, e delles se costumam servir. 
Há certas paragens no Ta-/cuarí; aonde se tem já encontrado com elles as/Canoas por serem baixios donde custumaõ pas-/sar; e se virão bem embaraçados com elles. As/ armas, de que uzaõ saõ Lanças compridas, e Laços; porem nunca no rio se podem servir/ taõbem dellas; pois o naõ ajuda ali a ligeire-/ za dos cavalos. Nos pouzos taõbem naõ há/ receio delles; porque estes se fazem em matos,/ em que elles perdem a ventagem dos cavalos, em que consiste a sua maior força. Pelo que só/ hum ataque repentino, e imprevisto naquel-/las paragens, sem que dé Logar a se começa-/rem a servir das armas de fogo, hé que po-/de cauzar destroço grande./
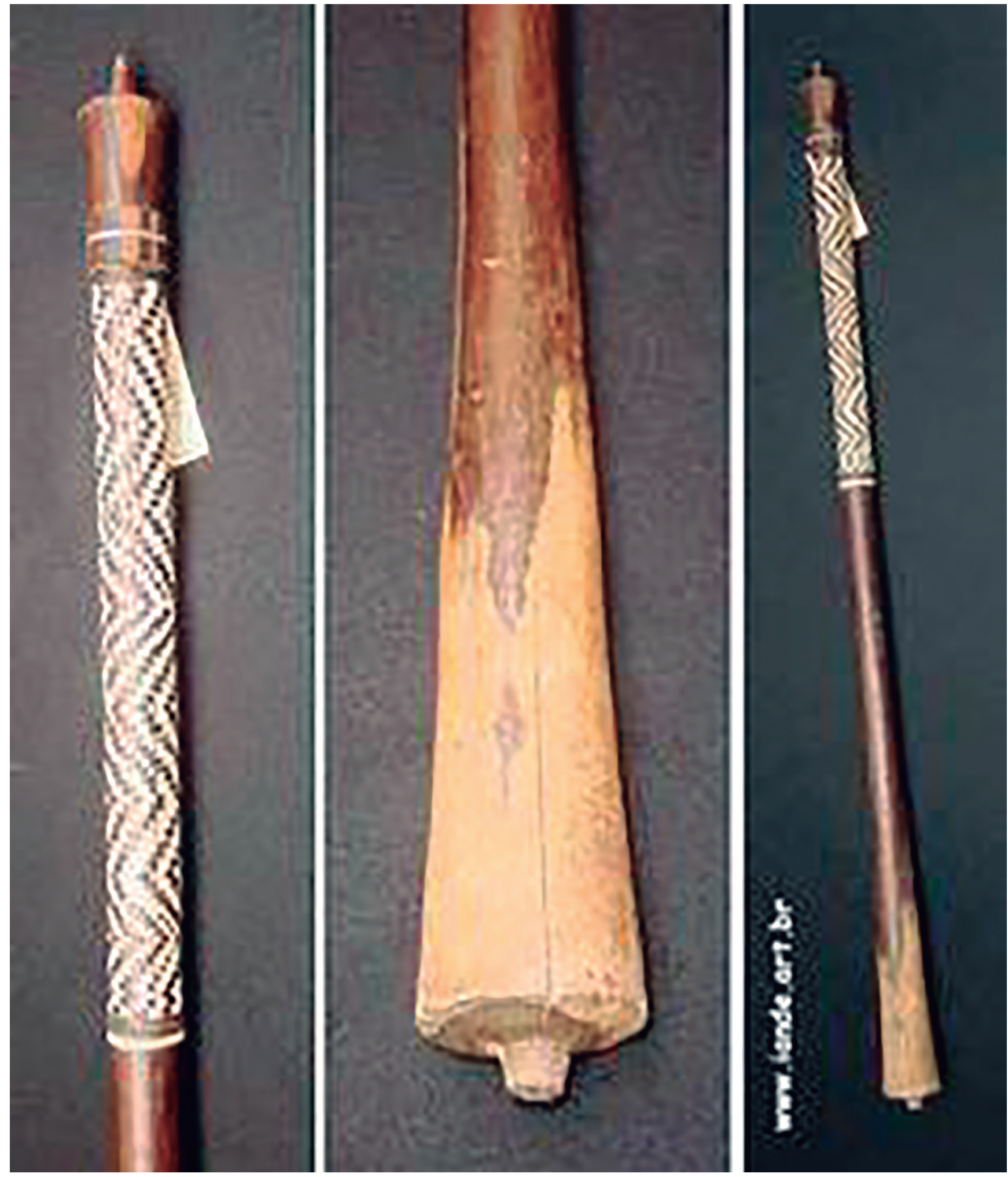

Figura 39. Tacape Kayapó. 
Fólio 28v

A terceira, e ultima hé do Paiagoa, e a de/ quem temos recebido mais, e maiores damnos:/ servem-se de arco, e frexa, e taõbem de Lan-/ças pequenas com pontas de ferro muito a-/gudas com as quaes ofendem de perto, e taõ-/bem de arremesso. Os seus ataques saõ de/ ordinario nos Rios, e em canoa; porque em ter-/ra naõ valem nada, e tres ou quatro armas/de fogo bastão a fazer opoziçaõ a hum gran-/de numero delles. Em cada canoa embar-/cão oito até dez, metade dos quaes rema, e/ a outra se serve das armas. A sua povoaçaõ/ está muito perto da Cidade da Assumpção. Quando os rios enchem, e fazem pantanais pe-/las suas margens, sobem entaõ a vir buscar o nosso Caminho, buscando sempre os mesmos/ pantanais, e logares deficeis ás nossas cano-/as por se naõ verem obrigados a baterem-se/ com nosco por força, o que Ihe socederia se an-/dassem pela madre dos rios, aonde encontran-/do-nos naõ poderiaõ escapar com facilidade./

A sual/

\section{Fólio 29r}

A sua cautela hé grande, e nunca atacaõ tropa/ algũa, sem que primeiro a venhaõ vigiando mui-/to tempo. Escondem-se pelos ribeiroens, e san-/gradouros; que dezembocaõ nos rios por onde hé/ a nossa viagem, para o que tem maior facili-/dade no Paraguai merim, e no Paraguai gran-/de, e quando os rios Levaõ já muita agoa no/ mesmo rio Cuiabá até muito junto do porto.

Dali nos espiaõ, e qu-/ando nos vem descuidados, saem derrepente com/ hũa grande gritaria, e o seu empenho todo hé/ molhar-nos as armas, e abordar para se li-/vrarem do damno, que dellas recebem, se nos/daõ Lugar a isso. Suposto pois o que tinha/dito me preveni para os receber da forma se-/guinte. Mandei pôr Lestas, e dezembaraça-/das tres canoas mandando tirar dellas tudo/ o que podia servir de algum impedimento/ dos Soldados para qualquer acçaõ, ou de fogo,/ ou de maõ. Em duas, que havião fazer a vam-/guarda, e retaguarda mandei meter dezoito ho-/

mens//

\section{Fólio 29v}

homens em cada hũa; os primeiros comanda-/dos pelo Capitaõ, e os segundos pelo Tenente;/ estes estavaõ em duas fileiras, e os dividi em/ trez pelotoens de vamgoarda a retaguarda;/ porem na ordem do fogo mandava para/ o conservar melhor dar separadamente fogo,/ primeiro a retagarda, e depois a vangoar-/da, e desta sorte fazia dos tres pelotoens seis/fogos; por quanto ainda que pareça muito pou-/ co tres armas para hum fogo, naõ hé para/ estes inimigos; os quaes vendo a continuação/ do fogo, $e$ perdendo alguns dos seus, ainda que/ poucos, hé o que basta para atemorizar, e fa-/zer fugir.

Na terceira, que havia hir no/ centro de toda a tropa mandei montar hũa/ pecinha de amiudar 49 (Fig. 40), que havia trazido do Rio/de Janeiro, a qual ficou taõbem na Canoa,/ que com grande facilidade fazia fogo so-/bre hum, e outro bordo, sem embaraçar de nenhum modo a marcha. Esta canoa en-/

tre-//

\section{Fólio 30r [11.12.1750]}

entreguei Logo ao Alferes com onze homens./Nesta forma os exercitei até ficarem ha-/beis e promptos.

Depois de haver estado naquel-/le citio alguns dias, como naõ tivesse chegado/ o Juiz de Fóra, me mudei mais para diante/ por evitar algũa corrupçaõ do ar com a dema-/ziada estada no mesmo Lugar, principalmen-/te começando já a ter algum maõ [sic] cheiro pel-/la muita Cassa, que se havia morto. A on-/ze me púz em marcha tendo já chegado o/Juiz de Fóra, e a doze por me hir avizinhando/ao destricto das passagens do Cavaleiro, e do Pay-/agoa dispúz as canoas na forma seguinte.

Na vanguarda a em que hia/ o Capitaõ, em que me meti taõbem com/ o Ajudante de Tenente; na retaguarda a/ do Tenente, na qual mandei embarcar o/ Tenente General: no Centro a do Alferes com/ a pecinha. Do centro para a vangoarda, e/ do Centro para a retaguarda marchavão/

49 Pecinhas de amiudar - Inventada por Frederico Jacob Weinholtz, contratado como Instrutor de Artilharia em 1736 pela Coroa Portuguesa, para introduzir novas peças de artilharia nas forças militares de Portugal. Essa peça de artilharia disparava até vinte balas por minuto, lançando uma espécie de granada que se amiudava, foi utilizada pelos portugueses na índia em 1740 . No Brasil, 0 Governador do Pará Francisco Xavier de Mendonça Furtado em carta ao irmão (Conde de Oeiras e futuro Marquês de Pombal) datada de 9 de novembro de 1752, solicitou 0 envio de pecinhas de amiudar para prevenir qualquer ataque por parte dos paiaguá. Era assentada nas canoas artilhadas perto da proa, em uma carretinha sobre um pranchão, onde podia fazer fogo para todos os lados (Mello, 2009: 336). 


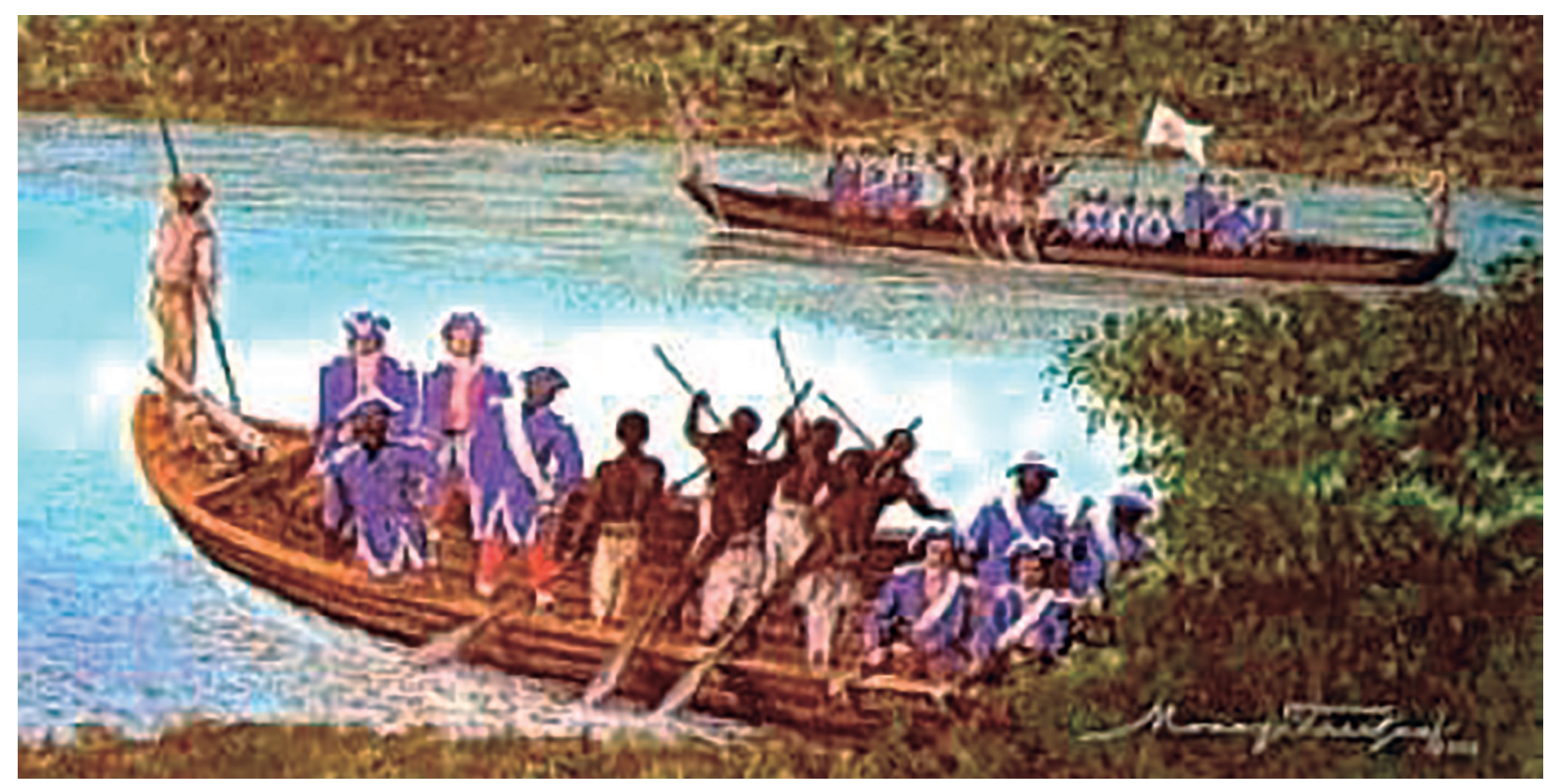

Figura 40. Canoa com "pecinha de amiudar" na proa.

\section{Fólio 30v [12.11.1750]}

as de carga. Meti taõbem nos mesmos in-/tervalos duas canoas de Guerra das que ti-/nha Levado o Capitaõ mór, para que naõ/ houvesse canoa algũa de carga, que naõ fos-/se á vista sempre de algũa de Guerra. Dis-/tante hum pedaço da vangoarda, mas sem-/pre á vista della, mandei hir hũa Canoi-/nha de montaria bem equipada para hir/ descobrindo, examinando todos os Logares/ de suspeita. Entre esta, e a da vangoarda/ marchavão todas as demais Canoas de monta-/ria, cujo Lugar lhe hé precizo para Cassar,/ e pescar fóra do maior ruido, que faz a tro-/pa. Somente rezervei hũa para que fosse/ á vista da minha com dois Soldados para le-/varem as minhas ordens tanto na marcha/ como na acçaõ, e muitas vezes me servi della/ para ver se a tropa vinha unida, o que eu/podia ver por cauza das voltas dos Rios.

A doze passei pela llha/ dos passaros, aonde saltei hum pouco em/

terra//

\section{Fólio 31r}

em terra. Hé aquella Ilha hũa das couzas/ raras, que se encontrão neste caminho. Daõ-/lhe aquelle nome por se criarem ali varias/ castas de passaros muito grandes, a que/ chamam Tuiuiús ${ }^{50}$, e outros nomes, que me naõ lem-/braõ. Estes quaze todos brancos, quando eu/passei naõ era já tempo de haverem tantos pe-/lo que me diceraõ; sem embargo que, quan-/do de longe avistamos a llha estavaõ as ar-/vores, que hé tudo mato fexado taõ cheias de/ taes passaros, que parecia roupa, que estava a enchugar. Cada hum dos cassadores se/ poz debaixo da sua arvore, e dali matou/ os que quis; porque por mais que cahissem/ os que ficavaõ na mesma arvore se naõ afas-/tavão. Em fim eu receei, que arrebentassem/algũas armas; pois naõ medeava mais tem-/po entre tiro, e tiro, que o que leva a carregar/só tinha hum disconto, que a menor parte/ era dos que vinhaõ abaixo. A sua mesma molidaõ os fazia ficar prezos nos ramos.

\section{Fólio 31v}

A treze dei fim ao Tacuari devidindo-se/ este em hũa quantidade de braços, e sangra-/douros pelos quaes dezagoaõ em huns lar-/guissimos Campos, formando nelles pan-/tanais taõ Largos, que a vista se perde pa-/ra lhe alcançar o fim. Alguns praticos Ihe/ daõ trinta e quarenta Legoas, e outros mui-/to mais afirmando, que se estende até a Ca-/choeira dos Parrudos, cuja fica para o cami-/nho que vem de Goyás. Este pantanal for-/ma varias bahias limpas, e em outras par-/tes marchavaõ as canoas por sima 
do Capim,/ e hũa casta de erva a que chamaõ Agoapé51 (Fig. 41), o/ que cresce debaixo d'Agoa, e com o lixo, e terra, que ella ajunta, fazem tal embaraço, que/ em partes era precizo abrir o caminho com/ enchadas, e machados. Noutras taõbem es-/tavão as ervas á flor da agoa, todas floridas/ de varias cores, o que formava hũa vista sũ-/mamente agradavel./

De espaço em espaço/

\section{Fólio 32r}

se levantaõ huns redutos cobertos de matto, que/ servem de pouzos; porem como por fora se/ parecem huns com os outros, nem há bali-/zas certas por onde se possa dirigir a viagem/pela largueza, e igualdade do pantanal,/ hé muito dificultozo acertar por elle o cami-/nho, em muitas vezes sucede ser precizo tornar/ atráz por se dár em partes mais secas, e que/ naõ permitem Levarem-se por ellas as ca-/noas; porem eu naõ errei hũa passada. A agoa deste pantanal e dos mais, que passei, hé clarissima. Naõ se lhe percebe movimen-/to, mas summamente mole, e taõ quente, que/ naõ hera precizo aquentar-se para fazer a barba: por cuja cauza a achei ainda pe-/or, que a dos rios que pela sua correnteza/ apanhava menos calor do Sol, sem embargo/ do que de camapuan até ás minas, cada vez/ vinha mais turba, e cheia de terra pela/ repetição das trovoadas.

No mesmo dial

fiquei//

\section{Fólio 32v [15.12.1750]}

fiquei arranchado em hum reduto, cujo matto/ heraõ palmitos, como estes tem hum tronco/grosso, e delle Lançaõ varios ramos em roda/todos arqueados, e estavaõ os taes palmitos bem/Companados [copados]; de qualquerparte, que se olhas-/se se via hũa rua como de quinta Cuberta com/aquella especie de abobada; formada daquelles/ ramos. Naõ somente foi agradavel a vista/ á quelle rancho; mas taõbem ao gosto; por que os palmitos eraõ de excelente qualidade,/ e foi a primeira vez que os comi cruz, em que/ Ihe naõ achei inferior sabor ao das castanhas; des-/contou-nos isto hũa praga de Carrapati-/nhos, que nos pegaraõ, e de que nos enchemos, que nos deu que fazer muitos dias. A estes por/destinçaõ dos outros chamaõ mecuins ${ }^{52}$.

A quinze/ á tardinha entrou no Paraguay merim, que hé/ hum braço do Paraguay grande, metendose/ entre este e aquelle hũa Ilha, que o forma. Tem sua deficuldade acertar por elle o cami-/

nho//

\section{Fólio 33r [17.12.1750]}

Caminho por se devidir em varios sangradou-/ros, e em partes por ser pantanal que se commu-/nica com o outro. Daqui até sahir do Pa-/raguai Grande hé aonde mais facilmente/ se encontra o Paiagoa por terem estes rios/muitas abertas, e sangradouros para os pan-/tanaes, de onde elles custumaõ dar, e taõ-/ bem por serem Largos, o que dificulta ás ca-/noas aportar á terra de donde com facili-/dade se defendem; por esta cauza marchei/ nestes dois rios com dobrada cautela.

A 17 en-/trei no Paraguay grande hum dos dois ma-/iores rios da America, e sendo aonde eu o/ naveguei taõ distante de sua barra; hé já/ ali caudalozissimo, tendo quaze a mesma/ Largura do rio grande. Por detráz das su-/as margens tanto de hũa, como da outra/ parte saõ pantanais e bahias muito Lar-/gas que com elle se communicaõ por sangra-/douro. Em hũa dellas me afirmou hum/

pra-//

\section{Fólio 33v}

pratico havia marchado em hua canoa doze/dias para chegaráterra firme, hindo ella/remada pordezaseis remeiros, pelo que me/ parece, que o largo [sic; lago] de Xaraes ${ }^{53}$ (Fig. 42) propriamen-/te começa no fim

51 Aguapé - Eichhornia crassipes (Mart.) Solms, 1883.

52 Micuim - Designação vulgar dos ácaros da fam. Trombiculidae, especialmente os do gênero Trombicula, que em sua fase larval costumam atacar o homem e os animais, causando fortes comichões.

53 A lagoa dos Xaraiés, lago dos Xaraiés, lago dos Xaraés (em português) ou laguna de los Jarayes (em castelhano) era um lago hipotético localizado nas nascentes do rio Paraguai. Foi retratado por cartógrafos e cronistas hispânicos do século XVII. Na verdade, 0 "lago" era resultado da interpretação errônea das observações do Pantanal na época das cheias por parte dos exploradores europeus. 0 nome "Xaraiés" significa "donos do rio" e foi aplicado a uma tribo indígena que existiu na região de Cáceres, no Mato Grosso. Sobre o assunto, ver os excelentes trabalhos de Costa (1999, 2007). 


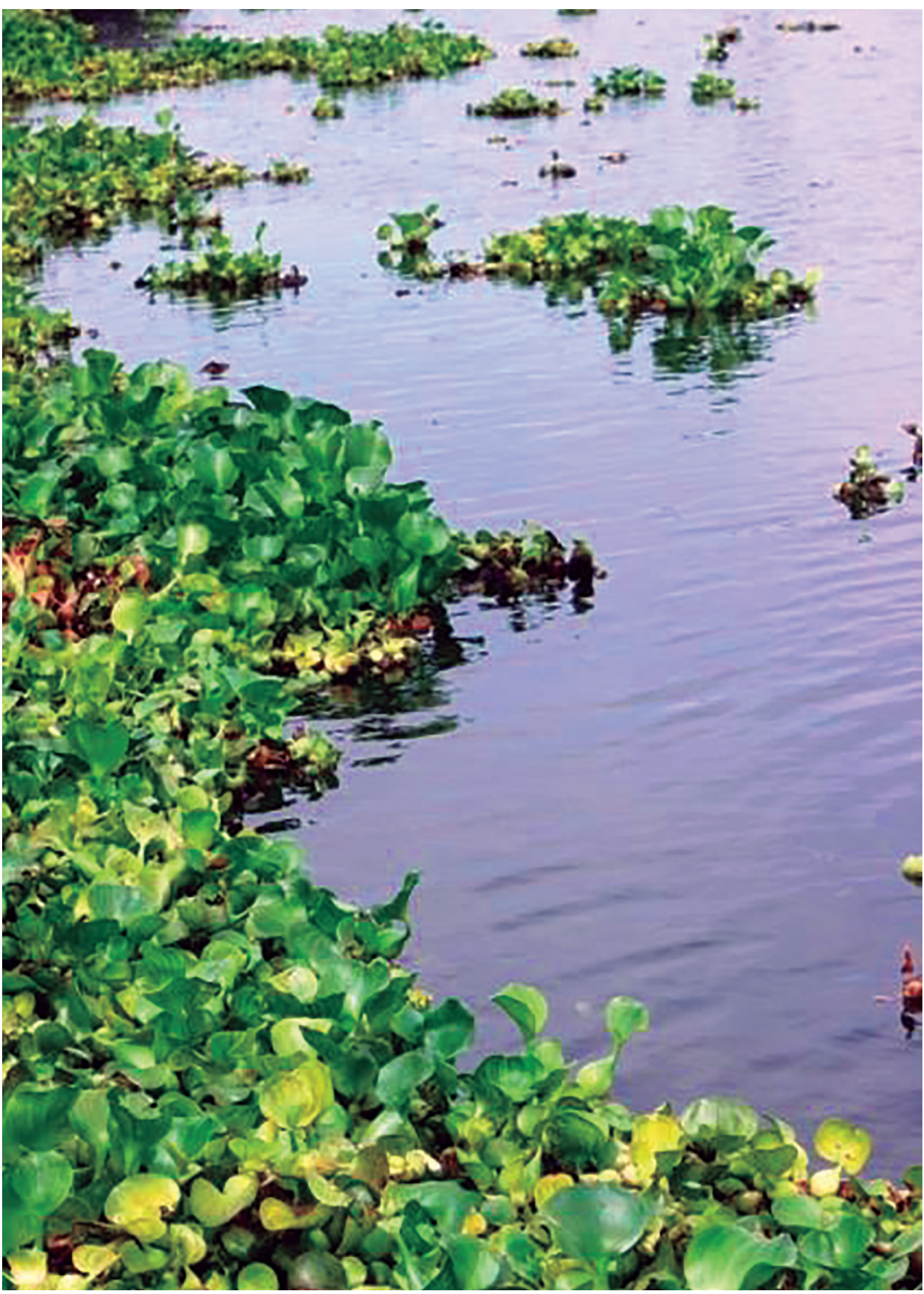

Figura 41. 'Este pantanal forma varias bahias limpas, eem outras partes marchavaõ as canoas por sima do Capim, e hũa casta de erva a que chamaõ Agoapé, o que cresce debaixo d'Agoa, e com o lixo, e terra, que ella ajunta, fazem tal embaraço, que em partes era precizo abrir o caminho com enchadas, e machados' [Fólio 31v]. 


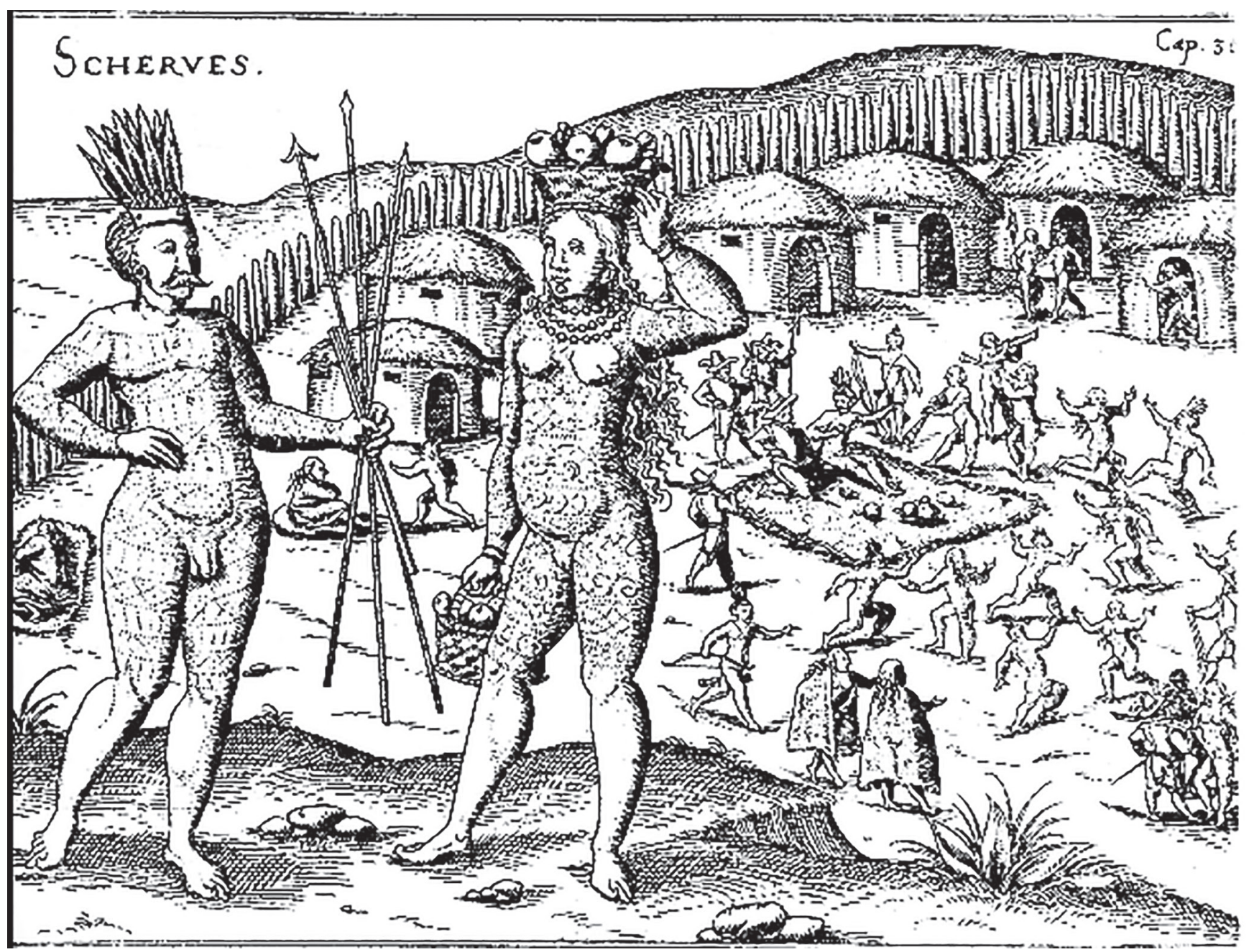

Figura 42. Índios Xaraiés (Sherves) (Hulsius, 1599: figura entre as pp. 49 e 50).

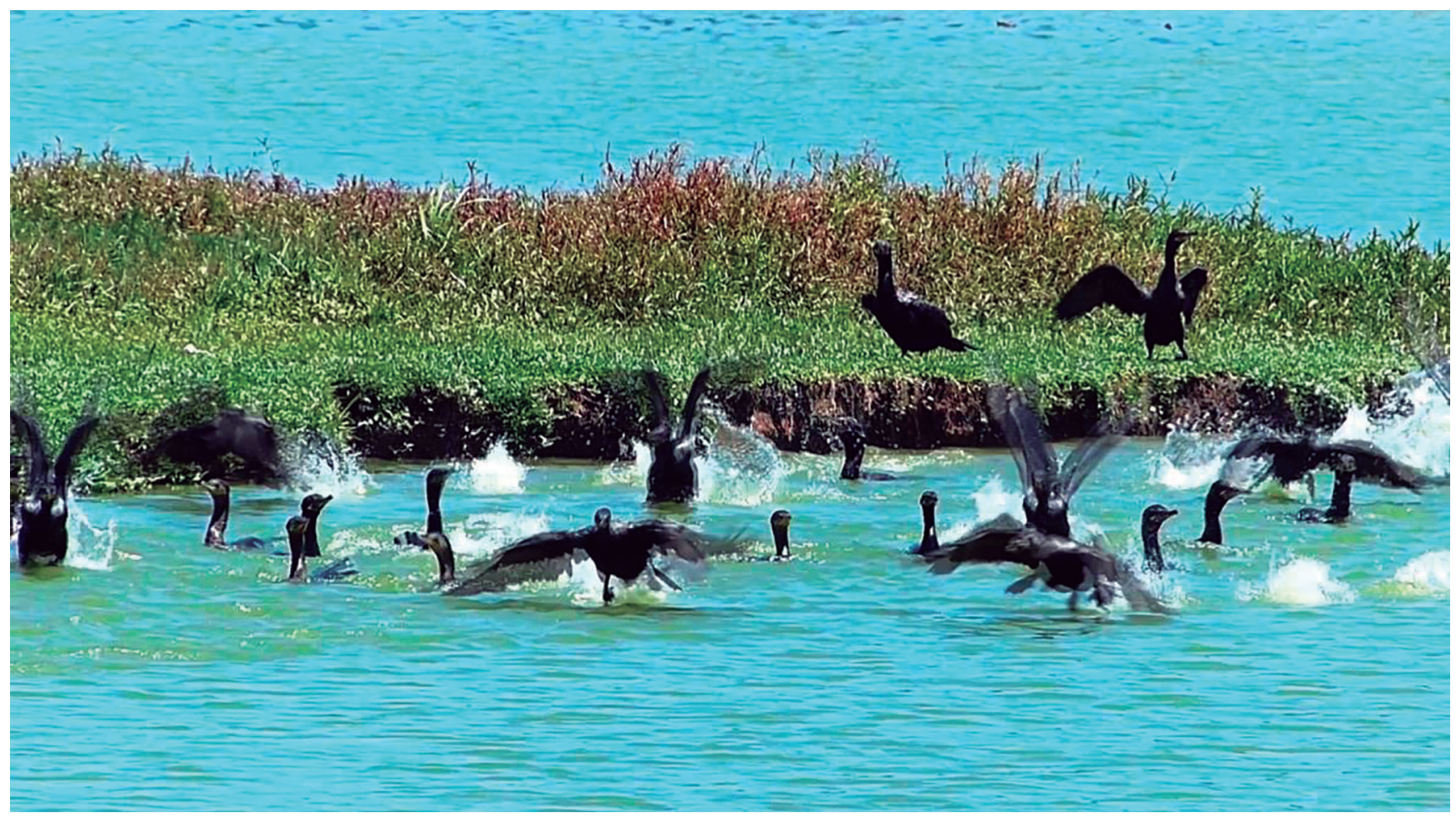

Figura 43. Revoada de biguás. 


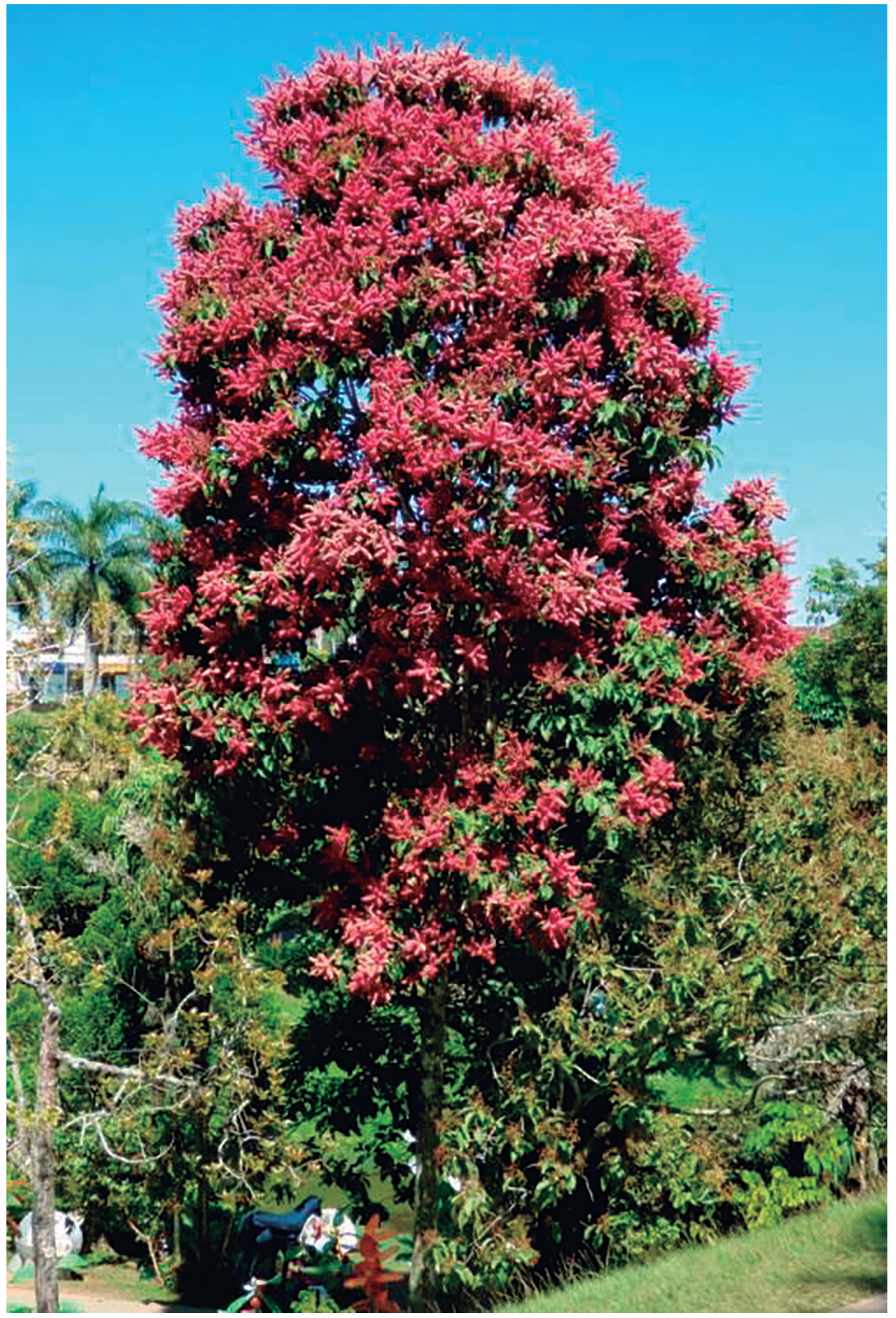

Figura 44. Pau-de-formiga, pau-de-novato ou taxizeiro (Triplaris americana). 

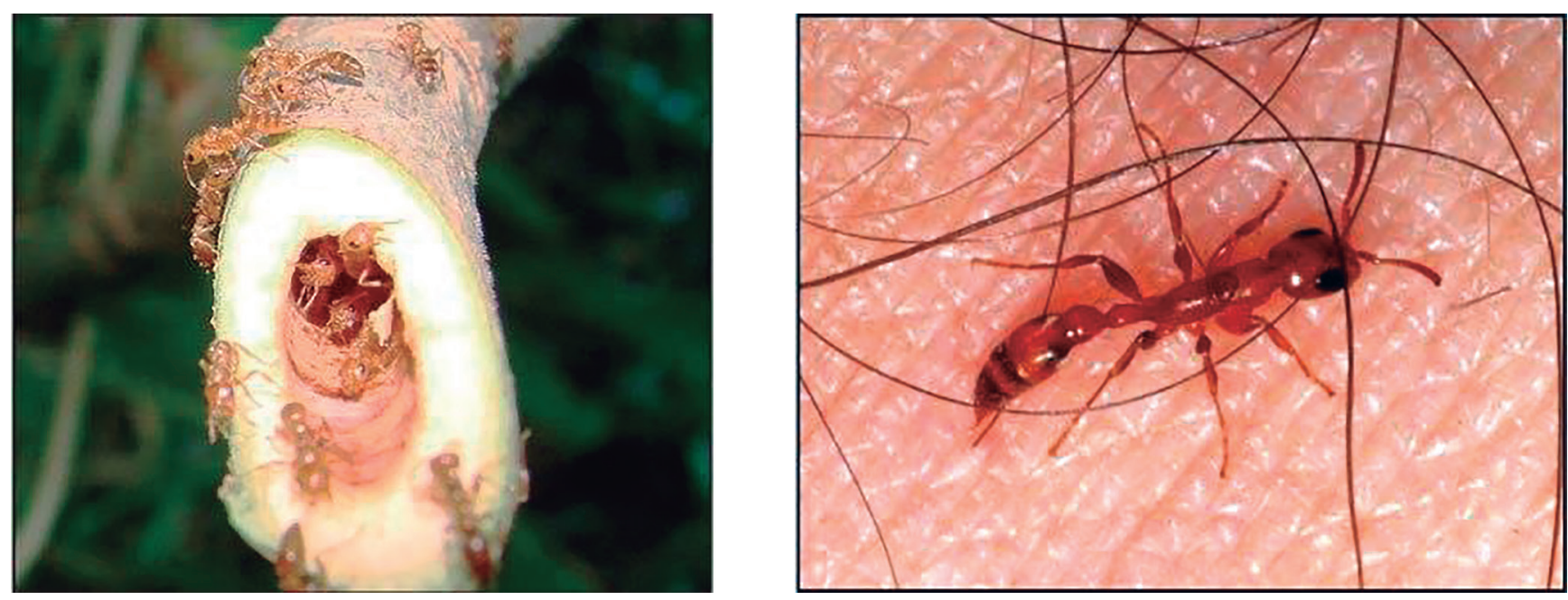

Figura 45. Psedomyrmex triplarinus - ataque após o corte de um ramo do taxizeiro e aspecto da formiga (Haddad Junior et al., 2009: figs. 2 e 3).

do Tacoari; pois desde aquel-/le Logar até ás vezinhanças do Matto Gros-/so, principalmente no tempo das agoas hé tudo/ hum pantanal, ficando só discubertos os mor-/ros, e alguns pedaços de restingas á borda do rio, de sorte que a quem fáz esta viagem naquel-/le tempo, lhe custa achar aonde fazer pouzo./

Neste mesmo dia chegando/ ao pouzo, foi tanto o Bigoa ${ }^{54}$ (Fig. 43), que comessou a le-/vantar-se da agoa, que cobriaõ os arres [sic; ares], e com/ o fogo, que se lhe fazia das canoas, parecia hũa/ descarga continuada, de sorte, que a [sic] ultimas ca-/noas ao principio entenderão, que as primeiras/andavaõ ás maõs com o Paiagoa. Naõ so-/mente desta Cassa, mas de toda a mais se a-/chou bastante neste rio./

\section{Fólio 34r [19.12.1750]}

A dezanove deixando-o á esaquerda tomei a di-/reita pelo Achianes [?], que hé hum braço dos/Porrudos. Em partes se passa por alagoas, e/ noutras, por pantanaes, em que os Agoapéz/faziaõ seu embaraço. De hũa véz foi precizo abrir/ o caminho à fouce, e ao machado; porque de todo es-/tava tapado por aquella erva, que começa a/ crescer do pé do barranco, e se estende tanto pa-/ra o meio do Rio, que tendo este bastante lar-/gura, ficava bem pouco espaço livre, e dezem-/baraçado, e naquelle lugar de todo havia fexa-/do o caminho.

Desde o fim de Tacoary co-/mecei a experimentar peores pouzos; porque/ com as muitas chuvas estavaõ as margens dos/rios alagadas, e os mesmos mattos molhados de/ sorte, que varias vezes nos vimos obrigados a/ comer o almoço e a Cêa meios engrolados./ A este discomodo se ajuntava outro maior. Aquelles matos desde a paragem, que disse a-/té estas minas estaõ cheios de algũas ar-1

vores//

\section{Fólio 34v [22.12.1750]}

arvores a que chamaõ paos de formigas ${ }^{55}$ (Figs. 44 e 45); porq'/ ellas se apoderaõ delle de forma, que nelles vivem,/ e delles se sustentaõ, e cada pao tem em si hua im-/mensidade. Se por engano se corta algum pao da-/quelles se espalhaõ, e fazem hũa perseguiçaõ extra-/ordinaria; porque a sua mordidela ainda que/ naõ faz inchar couza algũa, cauza hũa for taõ/vehemente como a das besperas.

A vinte e dois/ entrei nos Porrudos, que naquelle Lugar se de-/vide em dois braços, hum que conserva o seu/ [no]me, e vai buscar o Paraguay, o qual me ficou/ á esquerda, e o outro, que forma o Archianes, I por onde eu havia sobido; Logo mais adiante/ Lança o mesmo rio outro braço, que taõbem me/ ficou á esuerda, aonde se devide o caminho pa-/ra Mato Grosso; por cuja razaõ se chama hũa/ praia, que ali há - a praia dos abracos [sic] - por/ser o lugar até onde foraõ os de cuiabá no an-[no]/ de 35, ou de 36 acompanhar, e despedir-se dos/ primeiros descobridores, $q^{\prime}$ foraõ $p^{a}$ o matto grosso.

Neste//

54 Biguá - Phalacrocorax brasilianus (Gmelin, 1789). Erroneamente transcrito como "bigaz" por Varnhagen (1842: 493).

55 São as formigas-de-novato - "Pseudomyrmex ants (novice ants) live in cavities of the trunk and branches of the novice tree, the pau-de-novato (Triplaris spp.). The names novice ants and novice tree are associated with the fact that only those new to the region touch these trees, due to attacks by the ants. Triplaris americana is the most common species of novice tree. It is a large, beautiful tree (10-20 $\mathrm{m}$ high) that has a hollow trunk and branches. Its popular names are pau-formiga or pau-de-formiga (ant tree), pau-de-novato (novice tree), formigueiro (ant mound) and taxizeiro" (Haddad Junior et al., 2009: 727). 


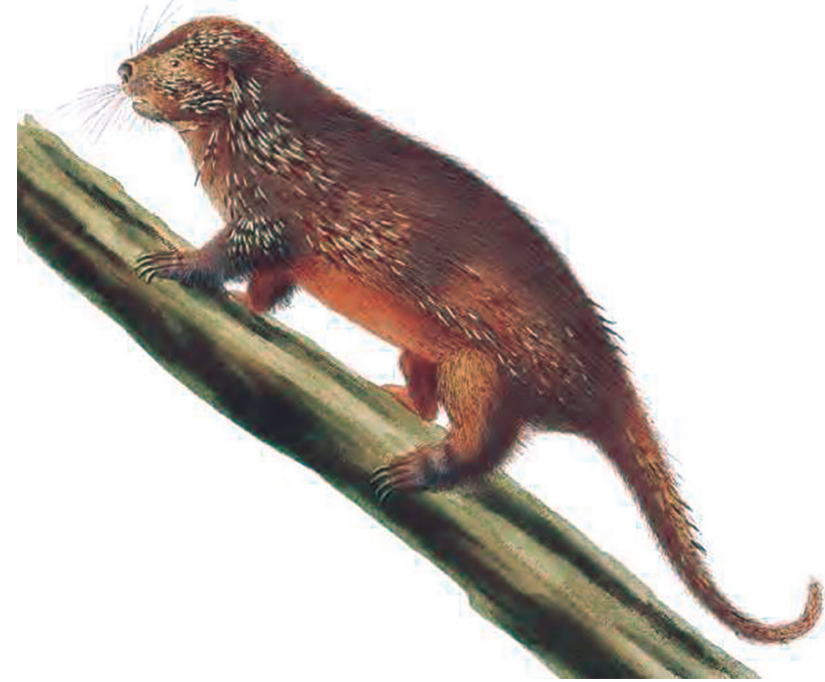

Figura 46. Ouriço-cacheiro.

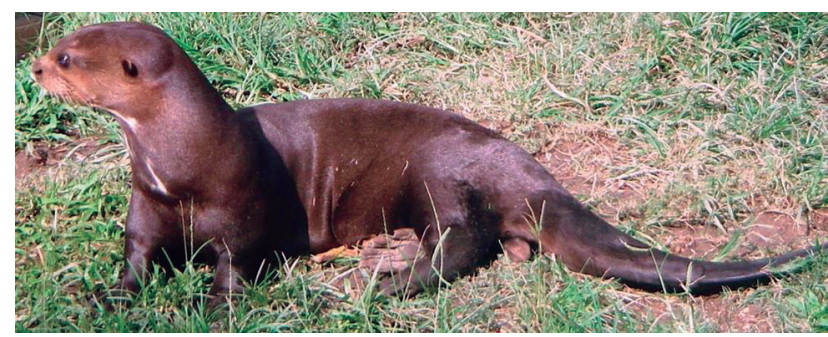

Figura 47. Ariranha.

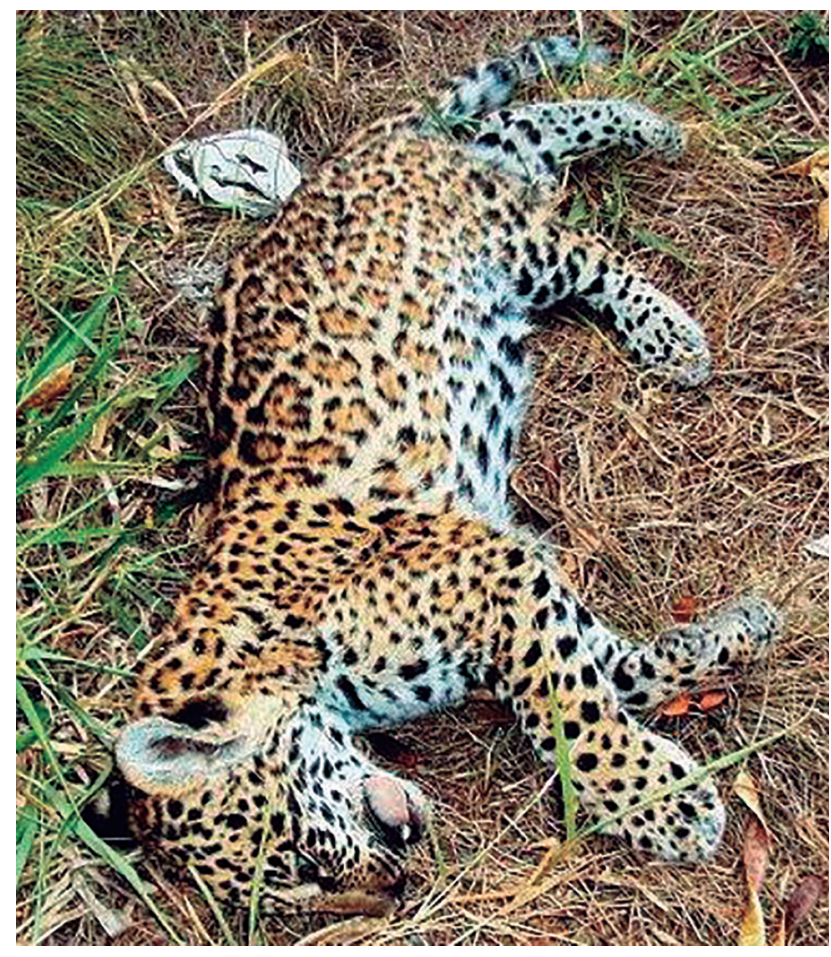

Figura 48. "A trinta se matou hũa onça nova...."

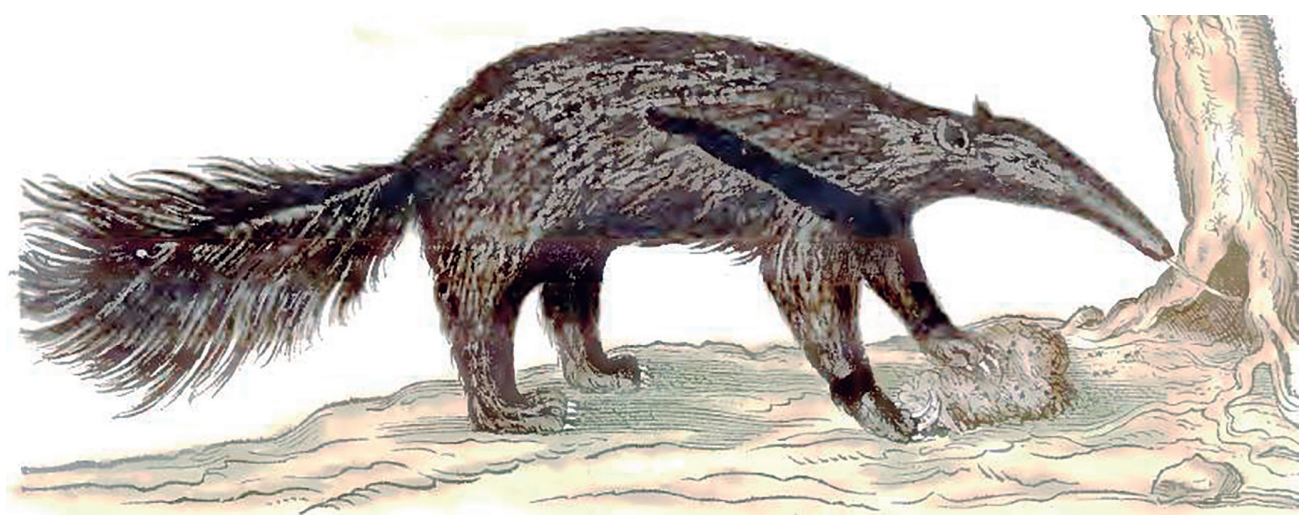

Figura 49. Tamanduá-bandeira (Marcgrave, 1648).

Fólio 35r [24.12.1750]

Neste mesmo dia, e no que se seguio corri ao/ Longo de hũa Ilha; que pela minha fantazia/ passa de tres Legoas de comprimento. Taõbem/ por aquelle tempo senti extraordinaria perseguiçaõ de mosquitos, que desde o Tacoary já/ nos davaõ bastante, que fazer. Eraõ estes de/ duas castas huns pernilongos do mesmo fei-/tio que os nossos, e outros a que chamaõ bran-/cos, que parecem hũa aresta; estes perse-/ guem de noite, e aquelles de dia, e as suas pi-/cadas deichaõ bolha, e comichão para mui-/to tempo, e eraõ tantos, que nos cansavamos/ em os enchotar; e nos naõ podiamos Livrar/ delles por mais que trabalhassemos. O ali-/vio, que tinhamos era quando apareciaõ huas/Borboletas ${ }^{56}$, que os comem. por que entaõ se/ somiaõ todos, e nos deichavaõ por algum/tempo; fora disso foi o maior martirio, que/ tive em toda a jornada.

A vinte, e quatro/ apareceraõ dois bichos novos, hum porco-espinho ${ }^{57}$ (Fig. 46)/ 


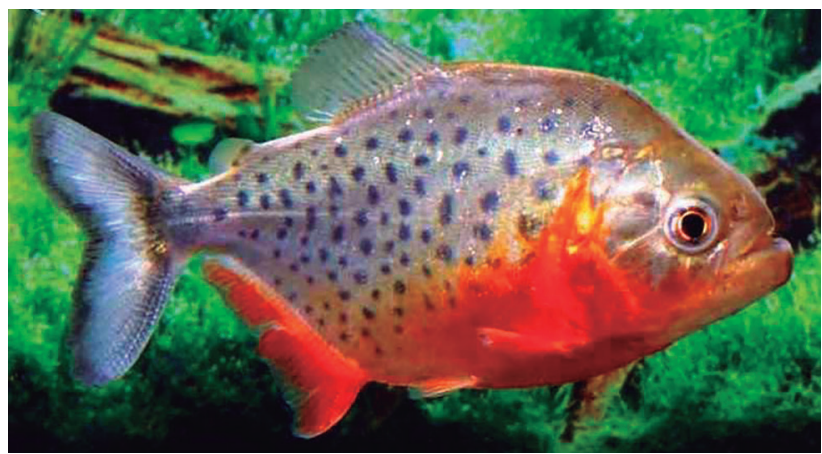
como as vem se deitaõ de costas, e quando a Onça lhe dá o Salto a apertão nos braços em que tem muita força, e com duas [sic] unhas, que tem em cada maõ muito rijas as atra/vessaõ até o coração" [Fólio 36v].
Figura 51. Piranha.

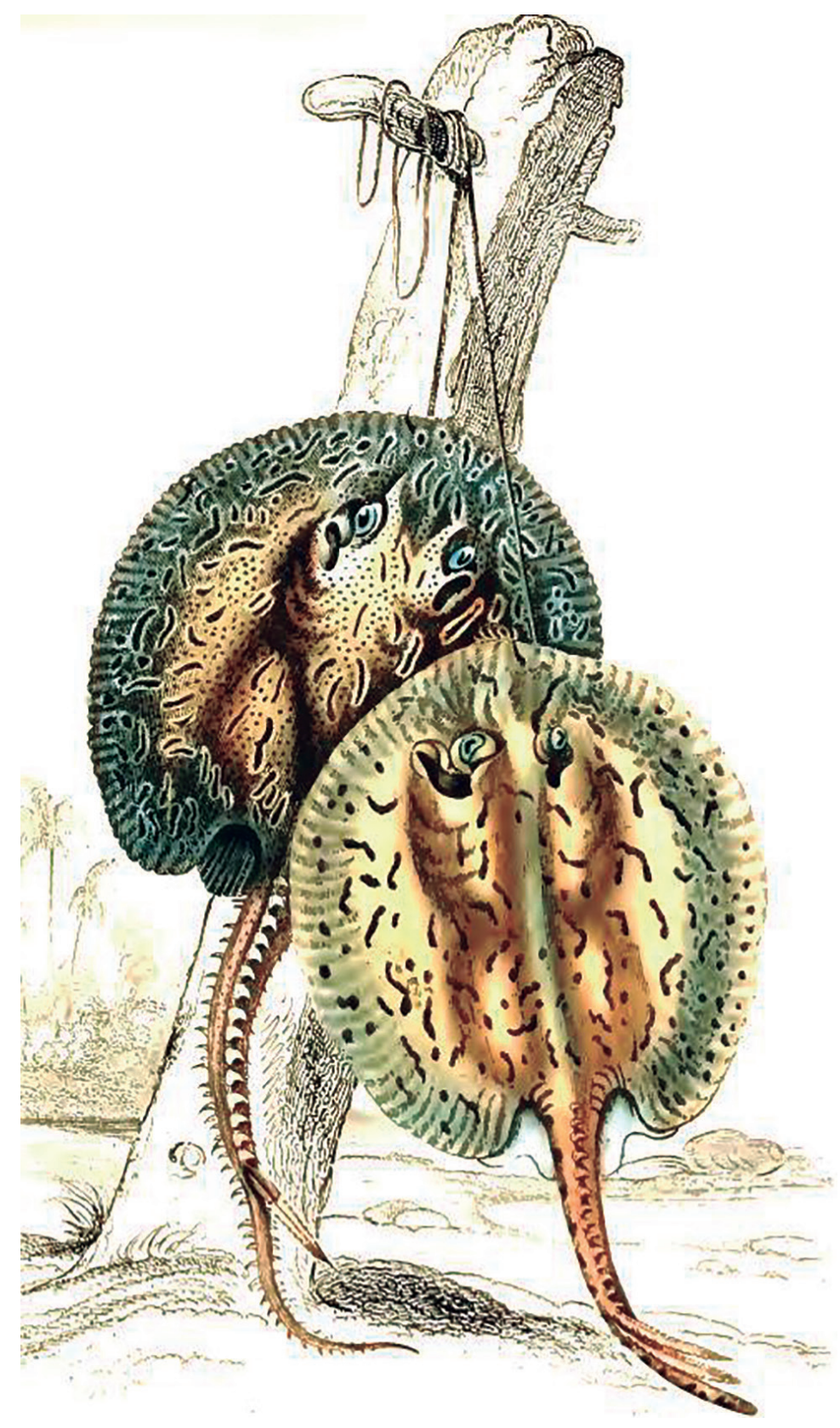

Figura 52. Arraia. 


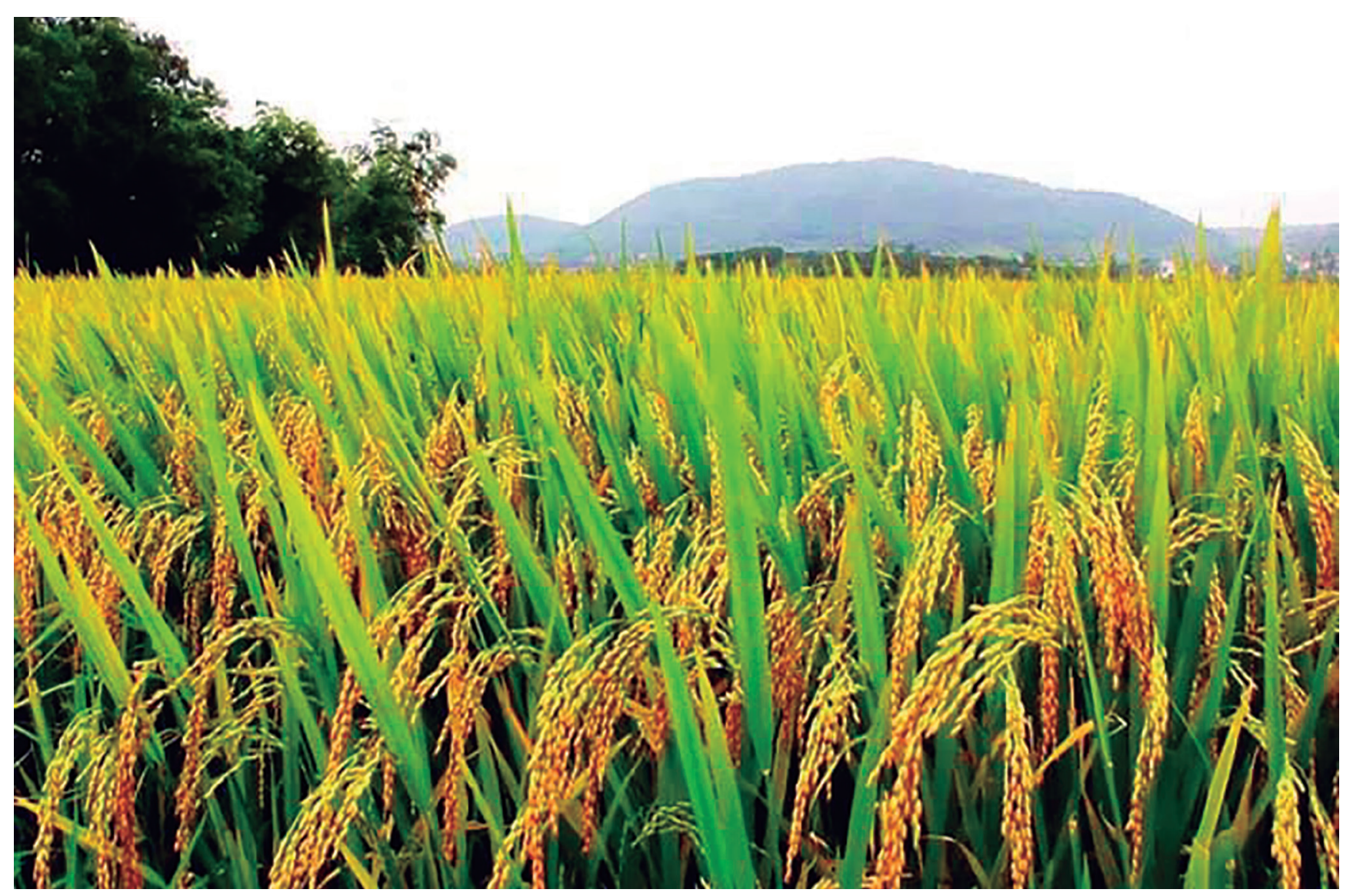

Figura 53. Arroz selvagem do Pantanal.

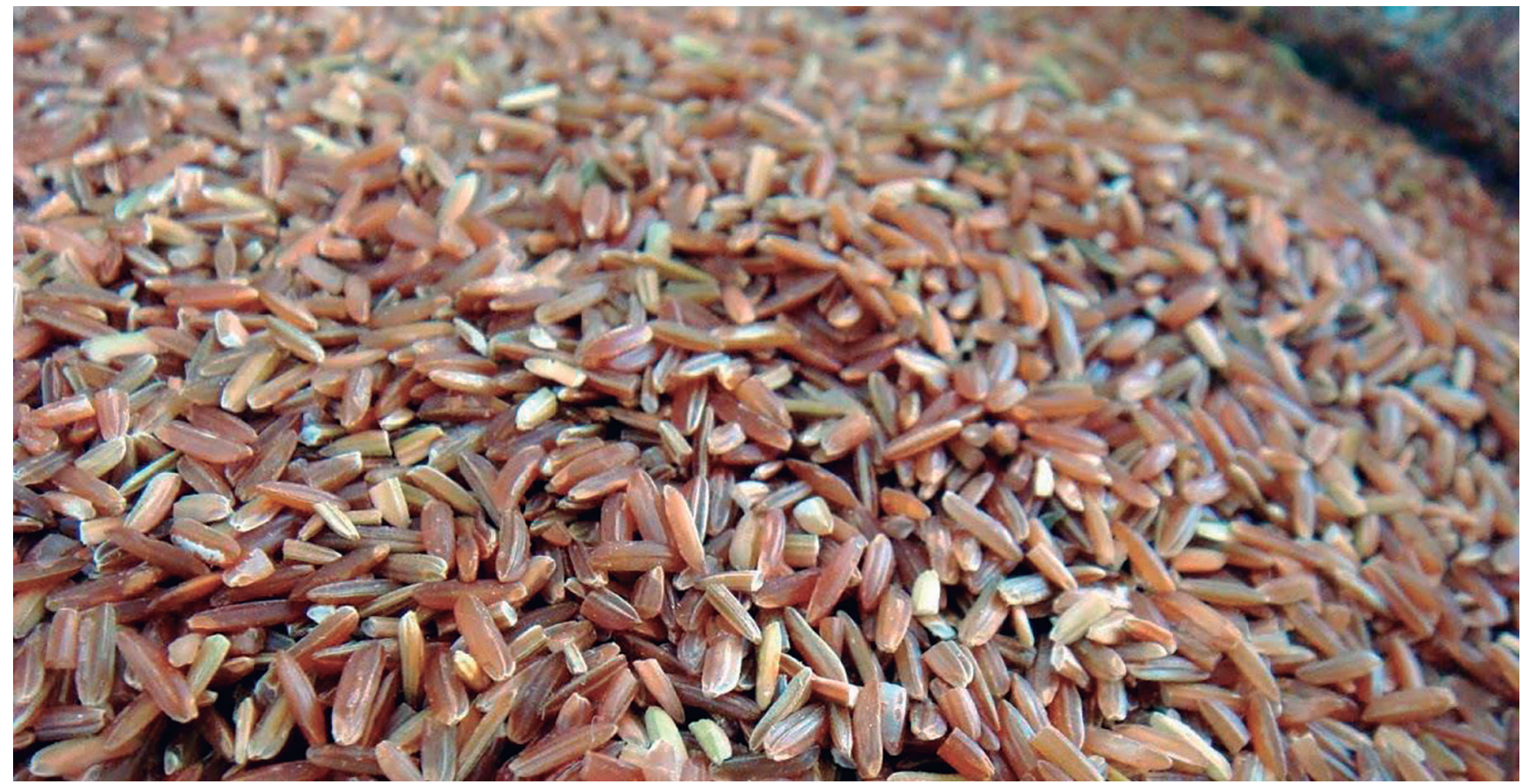

Figura 54. Grãos crus do arroz selvagem do Pantanal.

Fólio 35v [25-27.12.1750]

que se matou, e hum cachorro d'agoa 58 (Fig. 47), que se/ apanhou vivo. O primeiro hera do tamanho/de hum gato com o rabo comprido todo cheio/de espinhos agudos e compridos. No feitio se/ parecia mais 


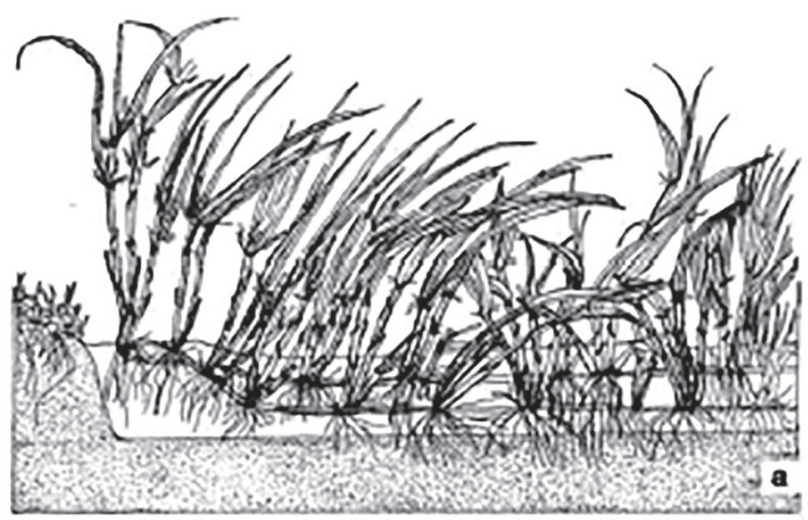

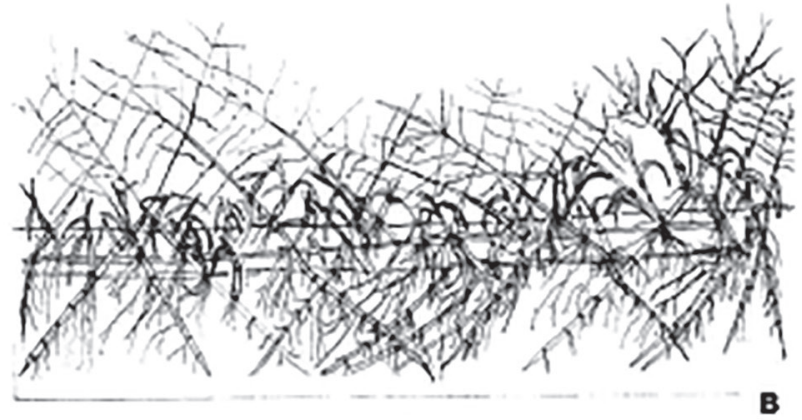

Figuras 2a-b. 2a Esquema da mancha de arroz-do-campo (Oryza latifolia) no plco da chela Quando chegs o plco da chela, as primetras sinfiorescênclasse abrem aumentando a area de cobertura da especse $2 b$. Esquema da mancha de arroz-do-campo ( $O$. Lotffolla) no periodo de vamante $Q$ uando a aqua comeca a batrar, dos nos de cada colmo que fica exposto na limina dagua rebrotam novos ramos.
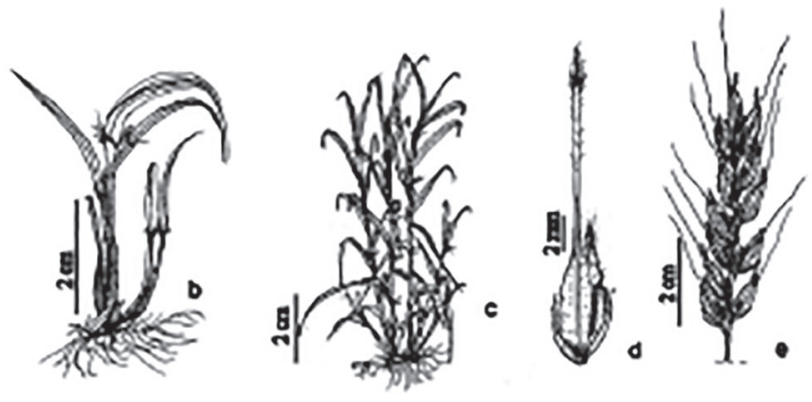

Piguras 3a-e. 3a. Esquerm da mancha de arroz-do-campo (O. lettyolta) na época da seca Quando as manchas de arroz secam, noros Indiriduos germinam na borda das manchas e tamberm novos ramos rebrotam dos colmos caldos no restante da mancha 3b. Plantula de $O$. intyolla que cresce na borda das manchas em época de seca completa, com as giumelas atnda presas as ratzer. 3c. Detalhe do ramo emergente do colma. 3d Esplgueta. que encerra of fruto. 3e. Espiguetas.

Figura 55. Arroz selvagem (Oryza latifolia) no Pantanal sul-mato-grossense (Bertazzoni \& Damasceno-Júnior, 2011).

com hum cão; o segundo taõ-/bem mas tem a diferença de ter os dedos de péz/ e mãos pegados, como os patos, o rabo comprido,/ e espalmado, e o pello sumamente fino, e ma-/cio. Andaõ sempre n'agoa, em que me dizem/ser taõ fortes, que mataõ as onças. Apanha-/dos, se domesticaõ muito, mas naõ sessão de Gritar.

A vinte, e cinco deichei este rio á maõ direi-/ta, e tomei pelo cuiabá, que a principio achei/ mais estreito, mas ao dipois alarga muito; por/ que ali vai unido, e para baixo se divide em va-/rios braços e sangradouros.

A vinte e sette che-/guei á caza de telha, cujo nome daõ áquelle/ Logar, por ter havido ali huns Citios com cazas/telhadas, que se dezamparou por cauza do Pay-/

agoa//

\section{Fólio 36r [30.12.1750 - 02.01.1751]}

Paiagoa, mas ficou ali sempre hum grande ba-/nanal, que serve aos passageiros por naõ ter/hoje dono. Quatro canoas se encherão dellas,/ que mandei repartir á tropa./

A trinta, se ma-/tou hũa onça ${ }^{59}$ nova (Fig. 48) do tamanho de hum gato/ grande, e do mesmo feitio muito pintada: foi/ morta indo com a May, que se escapou. Nes-/te rio há bastantes pelo que dizem; por que/ eu fóra esta somente vi outra, que o vinha atra-/vessando, e por mais deligencia de remo, q' se/féz para cortar o passo, o naõ pude conse-/guir; porque antes disso se lançou á terra, e/ se foi. Algũas vezes ouvi taõbem o seu ru-/gido ao Longe, e o rasto fresco em algũas par-/tes; porem suponho, que a bulha que fazia/ a tropa, e a repetição dos tiros á cassa, que apa-/recia, que era bastante, as desviava de nós. 
A dois de/ Janeiro se matou hum Tamandoa ${ }^{60}$ (Fig. 49), o bicho ma-/is raro, que encontrei desde que ando pelal

Ame-//

\section{Folio 36v}

America. O tamanho era de hum porco grande ao/ qual se parece nas sedas, ainda que muito mais/ crescidas, e com suas malhas. O rabo hé do feitio/ de hũa pluma taõ comprido e largo, que se cobre/ todo com elle. O focinho cumprido e agudo. A Lin-/goa em extremo delgada, e do comprimento de/ hum covado, ou mais. O seu sustento saõ for-/migas, que apanhaõ metendo a lingoa pelo ou-/co dos paõs [sic], em que ellas estaõ, e em sentindo/bastantes pegadas nella, a recolhem. Com u-/zarem de taõ fraco sustento saõ animaes mui-/to forçozos, de sorte, que mataõ as onças (Fig. 50). As-/sim como as vem se deitaõ de costas, e quan-/do a Onça Ihe dá o Salto a apertão nos braços/ em que tem muita força, e com duas [sic] unhas,/ que tem em cada maõ muito rijas as atra-/vessaõ até o coração ${ }^{61}$. Foi morto de hũa ca-/noinha, vindo nadando pelo rio, o que se/ féz com grande facilidade, dando-lhe com/ hum páo no focinho.

A muita agoa, que o rio levava e a grande corrente della da-/

vaõ//

\section{Fólio 37r}

davão hum grande trabalho aos remeiros, e com/ pouco fructo, porque naõ avançavaõ quazi na-/da; porque como as varas naõ chegavaõ ao/ fundo, custava infinito vencer com o remo a/ corrente. Pelo rigor do trabalho hiaõ adoecen-/do muitos remeiros, principalmente naõ os/deichando os mosquitos sossegar de noite, nem/ de dia, e achando os pouzos molhados. A isto/ se ajuntava hum calor excecivo, e chuva con-/ tinuadas. Nem podiaõ ter o refrigerio de se/ banharem no rio; por que do Paraguay pa-/ ra estas Minas há duas castas de peixe, q'/ o naõ consentem. Ao primeiro chamaõ Te-/zouras ${ }^{62}$ (Fig. 51): o seu tamanho hé de hum palmo; mas tem huns dentes taõ agudos e fortes, q'/ os vi varias vezes cortar anzoes capazes de/ sustentar peixes muito maiores. Pouco tem-/po basta, que apanhem hum homem n'a-/goa para o deixarem em miseravel estado.

A segunda Casta hé das Arrayas ${ }^{63}$ (Fig. 52),/ as quaes com hum ferrão, que tem no rabo,

daõ//

\section{Fólio 37v [03.01.1751]}

daõ picadas taõ peçonhentas, que os primei-/ros dias se naõ pode passar com [sic; sem] dores, prin-/ cipalmente as primeiras vinte, e quatro ho-/ras, e depois Levaõ muito tempo a curar-se,/ o que vi soceder ao proeiro da minha canoa,/ que sendo picado, passou até o outro dia em con-/tinuos gritos.

Pelo que tenho dito me rezolvi a/ trés a tomar pelo campo, deichando o rio á/ maõ direita. O cuiabá no tempo das agoas/fáz de hũa, e outra parte grandes pantana-/es, e chega a tomar tanta agoa, que por elles/se navega até junto da vila; porem nesta oc-/caziaõ ainda em partes naõ tinha a altura/ necessaria, e vime obrigado a buscar outra vez/ o rio. Sempre tive o gosto de ver com os meus/ olhos, o que já me tinhaõ contado mas naõ per-/suadido, e foi marchar com as canoas por/ sima de vastissimos arrozais, que naturalmen-/te sem serem plantados crescem por aquel-/le pantanal, e ali o vem colher todos os an-/

nos//

60 Tamanduá-bandeira - Myrmecophaga tridactyla Linnaeus, 1758.

61 Efetivamente os tamanduás-bandeira se defendem valentemente de ataques de onças, mas o que registrou o Conde de Aambuja é puro produto da imaginação popular.

62 Piranhas - Já G.S. de Souza [1587] 1851: 301 registrava:'Piranha quer dizer tesoura: é peixe de rios grandes, e onde o ha, é muito; e é da feição dos sargos, e maior, de côr mui prateada; este peixe é muito gordo e gostoso, e toma-se á linha; mas tem taes dentes que corta 0 anzol cerceo; pelo que os indios se não atrevem a meter n'agoa onde ha este peixe; porque remete a elles muito e morde-os cruelmente; se lhes alcançam os genitaes, leva-lhos cerceos, e o mesmo faz á caça que atravessa os rios onde este peixe anda'. Os índios, que só conheceram a tesoura (instrumento) após achegada dos europeus, compararam seu poder de corte com os dentes das piranhas e passaram a designar o instrumento com este último nome. 0 oposto ocorreu com os porugueses, que passaram a designar as piranhas como'tesouras'.

63 Designação comum a vários condrícties raiiformes da fam. Potamotrygonidae, de água doce. Acidentes com arraias da família Potamotrygonidae são muito comuns no Brasil. São animais de água doce e possuem de 1 a 3 ferrões de dentina, localizados na base da cauda, usados na defesa do animal. 0 ferrão é coberto por uma bainha tegumentar contendo glândulas mucosas e de veneno. Os acidentes geralmente acontecem quando as pessoas pisam no dorso do animal, escondido sob a areia. Por consequência, a arraia introduz o ferrão no pé ou no calcanhar da vítima, causando um ferimento extremamente dolorido, que muitas vezes infecciona e leva à necrose do tecido (Lameiras et al., 2013: 11; consultar este trabalho para mais informações sobre o veneno dessas arraias e os acidentes que causa). 


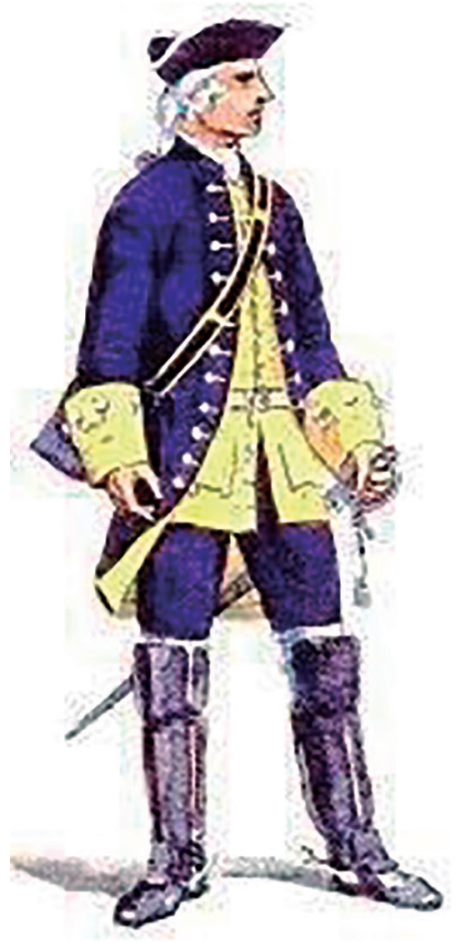

SOLOAOO OA.TKGIA

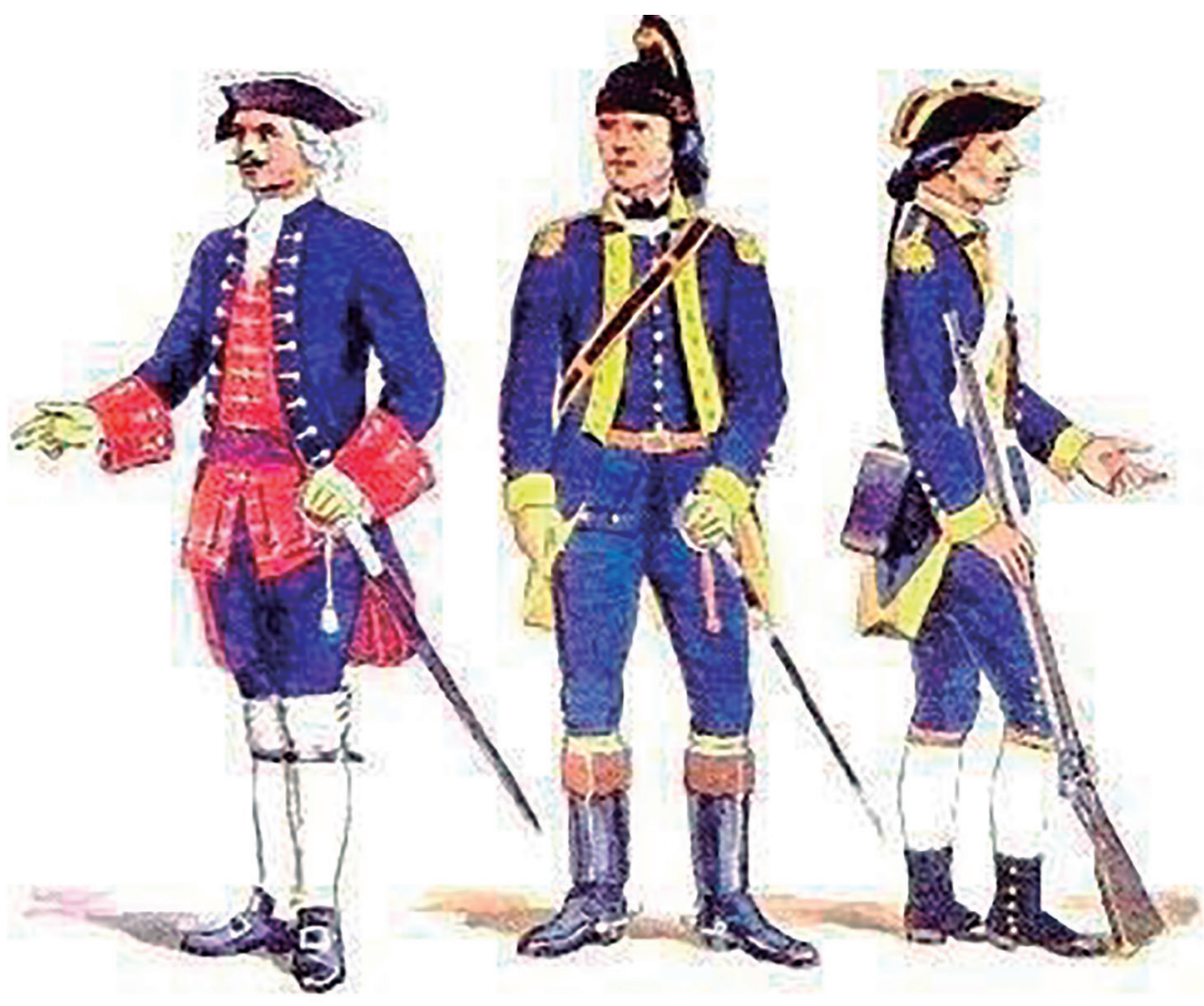

CRIELAL DA 2: CIA

SOLOADOS

Figura 56. Dragões e seus uniformes.

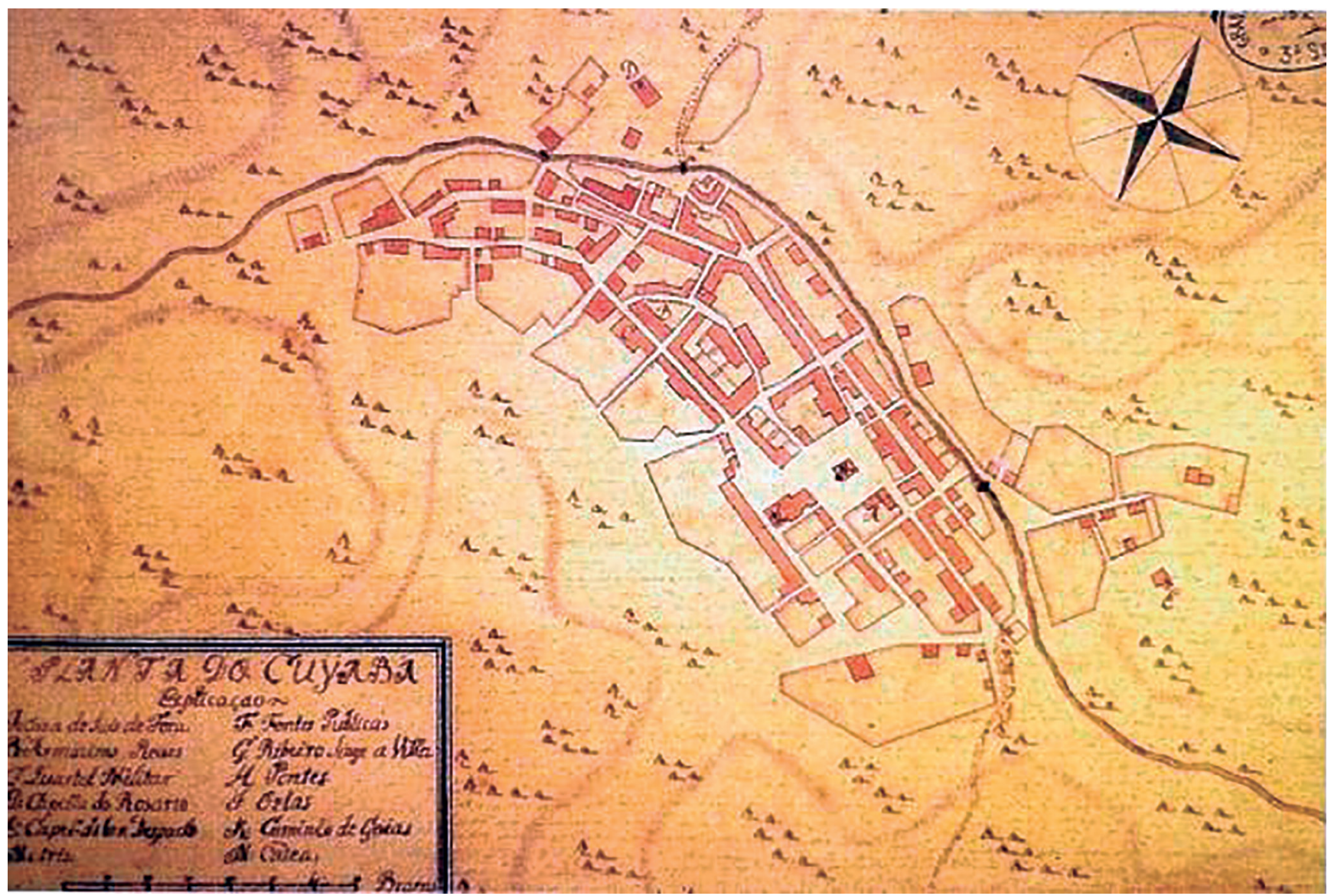

Figura 57. Planta da Villa Real do Senhor Bom Jesus do Cuyabá (século XVIIII). 


\section{Fólio 38r [06.01.1751]}

annos o Gentio. Quanto mais as agoas cres-/cem tanto mais cresce o arrós de sorte, que/ sempre está cinco ou seis palmos fóra d'a-/goa ${ }^{64}$ (Figs. 53-55). Naõ era todo o pantanal cheio de-/le, mas estava em rodellas entrechassado/com o capim, do qual vi algum já com o/ graõ formado.

Como a cada vez custava mais/vencer a corrente sem embargo de ser mal so-/cedido a primeira vez, a seis tornei a tomar o/ pantanal deichando o Rio á maõ esquerda, e/ entrei nelle por hum sangradouro, que chamaõ/ o cuiabá merim. Hera aquelle pantanal di-/ferente dos outros; porque eraõ tudo bahias/ muito Largas, e Limpas, e com bastante al-/tura d'agoa. Para passar de huas a outras/ se atravessaõ pedaços, que estavaõ cubertos de/ capim, e Agoapé, o que lhe servia de divizaõ./ Naquelle dia passei quatro bahias todas/Largas; mas na ultima me pareceu, que es-/tava no porto de Lisboa pela sua Largura,

\section{Fólio 38v [07.01.1751]}

e ainda pelas ondas, que fazia, o que naõ dei-/chou de dar algum cuidado; porque as enmbarca-/çoens, em que hiamos, naõ saõ para rezistir/ a ondas, se naõ para passar cachoeiras. Qu-/ando lhe chegamos ao fim, era quaze nove ho-/rãs da noute; e por vir crescendo o vento, ain-/da que nos ficava a terra Longe naõ houve ma-/is remedio, que arrumar a hum pouco de agoa-/pé forte, que nos abrigava do vento, $e$ ali/ dormimos aquella noite bem mal ceados; por/ que naõ houve aonde se poder acender o Lume, nem/ Lenha para elle.

No dia seguinte, em q'/ o almoço se pareceu com a cêa antecedente, pas-/sei duas bahias mais, e na ultima me aper-/tou a vento de sorte, que nos encostamos taõbem/ a hum agoapé para nos abrigamos [sic] delle;/ mas como cada véz hia crescendo mais, e ali naõ/ estavamos com toda a Segurança; nos rezol-/vémos por melhor partido a continuar a via-/gem ainda que com algum risco. A não o ha-

ver//

\section{Fólio 39r [11.01.1751]}

haver por divertimento se podia marchar por/ ali pela Largueza, e alegria das bahias, cu-/jas margens ofereciaõ á vista hum belo paíz./ A ultima era a maior de todas; della entrei/ num sangradouro, que me conduzio outra véz/ ao rio aonde vi ja choupanas de pescadores. A onze vim ouvir missa a Santo Antonio,/ pequena Irmida, aonde ouvi missa, e acaba-/da ella mandei salvar o Santo com tres des-/ cargas de mosquetaria, e vinte e hũa pessa [sic].

Neste dia já algũas pessoas/me vieraõ encontrar em Canoas, e no seguinte/todos com os Ministros, e Camera, e me condu-/ziraõ até o porto, aonde estavaõ duas peças/de artelharia, que estiveraõ salvando desde/ que me avistarão. Ao saltar em terra me/ salvarão taõbem os Dragoens com tres des-/cargas de mosquetaria, e a peça com vinte/ e hum tiro [sic]. No porto tinhaõ todos seus/Cavalos, e estava taõbem hum preparado/ para mim por ter distancia até a villa (Fig. 57)/

de//

\section{Fólio 39v [17.01.1751]}

de meia Legoa, e me acompanharaõ todos a-/té á minha porta. Aos Principaes Convi-/dei a Cearem comigo. Ali estavaõ forma-/das as ordenanças da terra, muito bem far-/dadas de uniforme (Fig. 56), as quaes eu mandei se tirar,/e antes de o fazerem deraõ tres descargas; e no Do-/mingo seguinte, dezassete do mez tomei posse//.

\section{AGRADECIMENTO}

À Profa. Dra. Maria de Fátima Gomes Costa, do Departamento de História da Universidade Federal do Mato Grosso, por sua gentileza em ler criticamente o texto.

64 No Pantanal brasileiro foi constatada a ocorrência de Oryza glumaepatula, 0. gradiglumis e 0. latifolia. Popularmente, essas espécies são conhecidas como arroz-do-campo, arroz-do-brejo ou arroz selvagem (Bertazzoni \& Damasceno-Júnior, 2011: 477). 


\section{REFERÊNCIAS}

Almeida, G.B. de. 2014. Os Juízes de Fora da Capitania de Mato Grosso e uma discussão em torno de suas rendas. Democracias e Ditaduras no Mundo Contemporâneo. In: Encontro da Associação Nacional de História, Seção Mato Grosso do Sul, 12 ${ }^{\circ}$. Aquidauana, MS. UFMS/CPAQ. http://www.encontro.ms.anpuh.org/resources/ anais/38/1411240492 ARQUIV0 ArtigoAquidauana.pdf.

Amado, J. 1995. Região, sertão, nação. Estudos Históricos, Rio de Janeiro, 8(15): 145-151.

Anôn. 1754. Relaçaõ da chegada, que teve a gente de Mato Groço, e agora se acha em companhia do Senhor D. Antonio Rolim desde o porto de Araritaguaba, até a esta Vila Real do Senhor Bom Jesus do Cuyabá. Na Officina Silva, Lisboa. Annaes da Bibliotheca Nacional do Rio de Janeiro, 20: 245-248, 1899. [Reproduzido, com a grafia original]

Anôn. 1977. Marcelino Pereira Cleto, Manuel Cardoso de Abreu, Luís dos Santos Vilhena, Martim Francisco Ribeiro de Andrada. Roteiros e Notícias de São Paulo Colonial. 1751-1804. Introdução e notas de Ernani da Silva Bruno. São Paulo, Governo do Estado de São Paulo. [Coleção Paulística vol. I].

Barbosa, F. de 0. [1792] 1843. Noticias da Capitania de S. Paulo, da America Meridional. Escriptas no anno de 1792 por Francisco de Oliveira Barboza. Revista trimensal de Historia e Geographia ou Jornal do Instituto Historico e Geographico Brazileiro, Rio de Janeiro, 5: 22-35.

Bertazzoni, E.C. \& Damasceno-Júnior, G.A. 2011. Aspectos da biologia e fenologia do Oryza latifolia Desv. (Poaceae) no Panatanal sul-mato-grossense. Acta Botanica Brasilica, 25(2): 476-486.

Camponez, M.R. [1766] 1856. Diario da expedição que ultimamente se fez desde o presidio da Nova Coimbra pelo rio Paraguay abaixo, por ordem do governador e capitão general das capitanias do Mato Grosso e Cuyabá, Luiz d'Albuquerque de Mello Pereira e Caceres, aonde principalmente se relatam algumas conferencias que se tiveram pela gente da mesma expedição com os índios guaycurús ou cavalleiros [Incluído no ofício enviado desde Vila Bela, aos 10 de janeiro de 1777 , a Martinho de Mello e Castro, por Luiz d'Albuquerque de Mello Pereira e Caceres]. Revista trimensal do Instituto Historico, Geographico e Ethnographico do Brasil, Rio de Janeiro 28(1): 70-88.

Canova, L. 2008a. Antônio Rolim de Moura: Um ilustrado na Capitania de Mato Grosso. Coletâneas do Nosso Tempo, 8(8): 75-86.

Canova, L. 2008b. Os índios em Mato Grosso no governo de Antônio Rolim de Moura (1751-1765). Histórica - Revista Eletrônica do Arquivo Público do Estado de São Paulo, São Paulo, 32: 1-11. Disponível em: http://www.historica.arquivoestado.sp.gov.br/materias/anteriores/edica032/materia04.

Canova, L. 2010. As representações de Antônio Rolim de Moura sobre a paisagem no interior da América portuguesa no século XVIII. Revista Crítica Histórica, 1(2): 116-140.

Canova, L. 2011. As representações do sertão na visão de Antônio Rolim de Moura. Revista NUPEM, Campo Mourão, 3(4): 39-58.

Canova, L. 2016. Índios e civilização na Capitania de Mato Grosso sob a perspectiva do Directório. Revista História e Diversidade, 8(1): 126-143.

Carvalho, F.A.L. de. 2014. "Com despesas próprias a bem do Real Servço": funcionários, colonos e a defesa da fronteira no extremo oeste da América portuguesa, c. 1750-1800. História, São Paulo, 33(1): 171-194.

Costa, M. de F. 1999. História de um País Inexistente: O Pantanal entre os séculos XVI e XVIII. São Paulo, Estação Liberdade \& Kosmos.

Costa, M. de F. 2007. De Xarayes ao Pantanal: A Cartografia de um mito geográfico. Revista do Instituto de Estudos Brasileiros, São Paulo, 45: 21-36.

Haddad Junior, V.; Bicudo, L.R.H. \& Franzoso, A. 2009. The Triplaria tree (Triplaris spp.) and Pseudomyrmex ants: a symbiotic relationship with risks of attacks for humans. Revista da Sociedade Brasileira de Medicina Tropical, 42(6): 727-729.

Hulsius, L. 1599. Vierte Schiffart. Warhafftige Historien einer wunderbaren Schiffart welche Ulrich Schmidel von Straubing von Anno 1534 bisz Anno 1554 in Americam oder Newen Welt bey Brasilia und Rio della Plata getham. Was für er in diesen Neuntzehen Jahren auszgestanden vnd was für seltzame wunderbare Lander vn Leuter gesehen: durch ermelten Schmidel selbs beschrieben an jetzt as ber an Tag geben mit Verbesserung vnd Corrigierung der Statt Länder vnd Flüsz Namen deszgleichen mit einer nothwendig Landtaffel Figuren vnd anderer mehr Erklerung gezieret durch Levinum Hvlsivm. Hulsij, Noribergae, Impensis Levini.

Ihering, R. von. 1940. Dicionário dos animais do Brasil. São Paulo, Secretaria da Agricultura, Indústria e Comércio do Estado de São Paulo, Diretoria de Publicidade Agrícola.

Keller-Leuzinger, F. 1874. The Amazon and Madeira rivers. Sketches and descriptions from the note-book of an explorer. With sixty-eight illustrations on wood. London, Chapman and Hall.

Lameiras, J.L.V.; Costa, 0.T.F. da; Santos, M.C. dos \& Duncan, W.L.P. 2013. Arraias de água doce (Chondrichthyes - Potamotrygonidae): Biologia, veneno e acidentes. Scientia Amazonia, 2(3): 11-27.

Lima, A.N. 2010. Caminhos da integração, fronteiras da política: a formação das províncias de Goiás e Mato Grosso. Dissertação de mestrado em História pela USP.

Mello, S.Á. de. 2009. 0 Arsenal de Marinha em Mato Grosso. Projeto político de defesa nacional e de disciplinarização do trabalho. Do planalto à planície pantaneira (1719-1873). Dissertação apresentada ao Programa de Pós-Graduação em História da Faculdade de Ciências Humanas da Universidade Federal da Grande Dourados, para obtenção do título de Mestre em História, Dourados.

Moura, C.F. 1982. Dom Antônio Rolim de Moura, Primeiro Conde de Azambuja. Biografia. Cuiabá, Imprensa Universitária, Universidade Federal do Mato Grosso. (Coleção Documentos Ibéricos, Série: Capitães-Generais, 1).

Papavero, N. \& Teixeira, D.M. 2007. A fauna de São Paulo nos séculos XVI a XVIII nos textos de viajantes, cronistas, missionários e relatos monçoeiros. São Paulo, Editora da Universidade de São Paulo.

Prado, F.R. do. [1793] 1839. Historia dos indios cavalleiros ou da nação Guaycuru escripta no Real Presidio de Coimbra por Francisco Rodrigues do Prado commandante do mesmo. Em que se descreve os seus usos e costumes, leis, allianças, ritos e governo domestico, e as hostilidades feitas a differentes nações barbaras, aos Portuguezes e Hespanhoes, males que ainda são presentes na memoria de todos - Anno de 1793. (Trasladado de um manuscipto offerecido ao Instituto pelo socio correspondente José Manoel do Rosario). Revista do Instituto Historico e Geographico do Brazil, Rio de Janeiro, 1(1): 21-44.

Souza, G.S. de. 1851. Tratado descriptivo do Brazil em 1587. Edição castigada pelo estudo e exame de muitos códices manuscriptos existentes no Brazil, em Portugal, Hespanha e França, e accrescentada de alguns comentarios à obra por Francisco Adolpho de Varnhagen. Rio de Janeiro, Typographia Universal de Laemmert.

Souza, J.S. de \& Makino, M. 2000. Diário da navegação. Teotônio José Juzarte. São Paulo, Editora da Universidade de São Paulo \& Imprensa Oficial.

Taunay, A. 1953. Relatos monçoeiros. São Paulo, Livraria Martins Editora. (Biblioteca Histórica Paulista IX).

Taunay, A.A. 1988. Aquarelas e desenhos de Taunay. Expedição Langsdorff ao Brasil 1821-1829. Volume 2. Rio de Janeiro, Edições Alumbramento. 
Teixeira, D.M. 1997. Brasil Holandês. Volume II. O "Thierbuch" e "Autobiografia" de Zacharias Wagener. Rio de Janeiro, Editora Index.

Varnhagen, F.A. de (Org.). 1842. Noticias praticas das minas do Cuiabá e Goyazes, na Capitania de S. Paulo e Cuiabá, que dá ao Rev. Padre Diogo Soares, o Capitão João Antonio Cabral Camello, sobre a viagem que fez às Minas do Cuiabá no anno de 1727. Revista Trimensal de Historia e Geographia, ou Jornal do Instituto Historico Geographico Brasileiro, Rio de Janeiro, 14: 487-500.

Varnhagen, F.A. de (Org.). 1846. Relação da viagem, que fez o conde de Azambuja, D. Antonio Rolim, da cidade de S. Paulo para a Villa do Cuyabá em 1751. Revista trimensal de Historia e Geographia ou Jornal do Instituto Historico e Geographico Brasileiro, Rio de Janeiro, 7(28): 433-497.

Veiga [Magro de Souza], M.F. da S. e. 1769. Falla que no dia 5 de Janeiro de 1766 em que se celebraram os felicissimos annos do III. ${ }^{\text {mo }}$ e Ex. ${ }^{\text {mo }}$ Senhor D. Antonio Alvares da Cunha conde do mesmo Titulo, do Conselho de Sua Magestade Fidelissima. . . Vice-Rei, e Capitão General do Estdo do Brasil. . disse, e offerece ao mesmo senhor em nome de todo o corpo da Relação do Rio de Janeiro o doutor Manoel Francisco da Silva e Veiga Desembargador de Aggravos da mesma, e Juiz Intendente do Real Confisco. Lisboa, Regia Officina Typographica.

Vilhena, L. dos S. 1935. Recopilação de noticias da Capitania de S. Paolo. Dividida em duas partes e acompanhada de duas plantas geographicas intereçantes e pouco vulgares para servir na parte que convier de elementos para a historia brasilica, Offerece e dedica ao ill. ${ }^{\text {mo }}$ e ex. ${ }^{\text {mo }}$ senhor D. Rodrigo de Souza Coutinho, Ministro e Secretario de Estado da Repartição da Fazenda, Presidente do Real Erario, Conselheiro de Estado de Sua Alteza o Principe Regente Nosso Senhor e Presidente da Bibliotheca Publica, Luiz dos Santos Vilhena Professor Regio de Lingua Grega na Cidade da Bahia. Lisboa MDCCCII. Bahia [= Salvador], Imprensa Official de Estado.

Washburn, C.A. 1871. The history of Paraguay. With notes of personal observation, and reminiscences of diplomacy under difficulties. In two volumes. Vol. I. I. Boston, Lee and Shepard, Publishers. 


\section{APÊNDICE}

A “Relaçaô da chegada que teve a gente de Mato Groço, e agora se acha em companhia do senhor D. Antonio Rolim desde 0 Porto de Araritaguaba, até a desta villa real do senhor Bom Jesus do Cuyabá" (Anôn., 1754), com a transcrição do opúsculo original nos Annaes da Bibliotheca Nacional do Rio de Janeiro 20: 245-248, 1899.

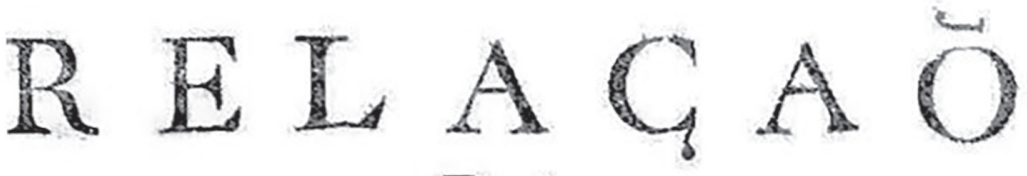

D A
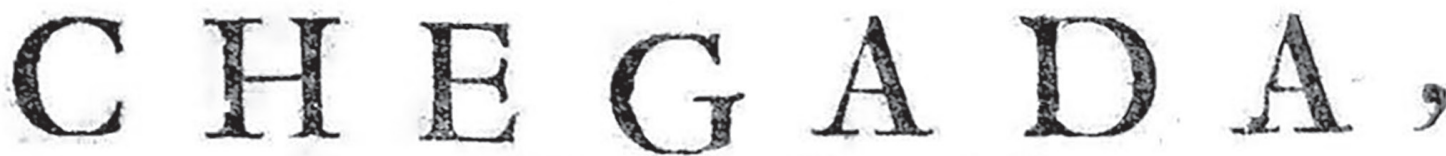

QUE TEVE A GENTE DE
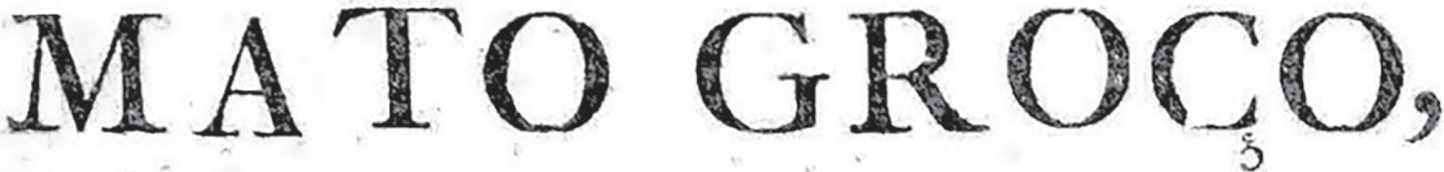

E AGORA SE ACHA EM COMPANHIA DO SENHOR
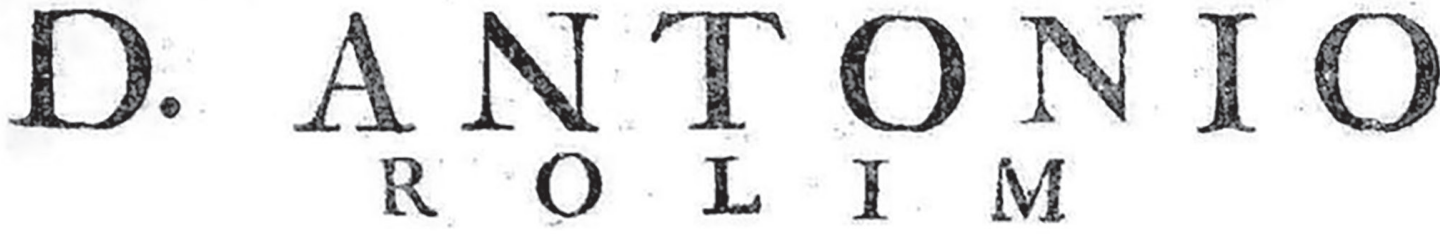

$\mathbf{L}$

I

$\mathrm{M}$

DESDE O PORTO DE ARARITAGUABA, ATR' a efta Villa Real do
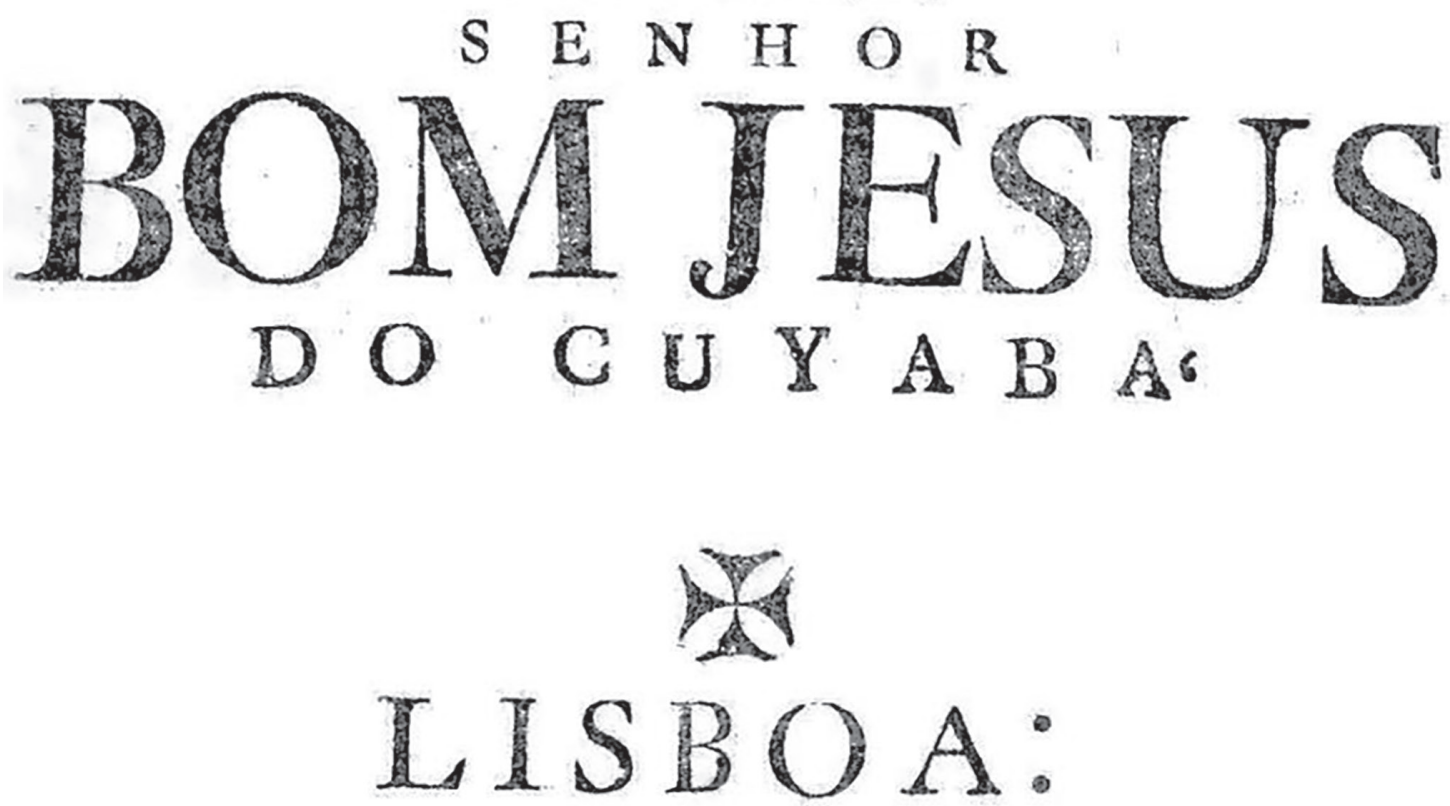

NA OFE PCINA SILVA.

$$
\text { Anno de } 17344 \text {. }
$$

Com ot das as licenças ucceffarias. 
Transcrição do opúsculo original nos Annaes da Bibliotheca Nacional do Rio de Janeiro 20: 245-248, 1899.

\section{relaçaö | da Chegada, | que teve a gente de | MATO GROÇO, | E AGORA SE ACHA EM COMPANHIA DO SENHOR | D. ANTONIO|ROLIM|DESDE O PORTO DE ARARITAGUABa, ATÉ|á esta Villa Real do|senhor|BOM JESUS|Do CUYABA.}

LISBOA :

NA OFFICINA SILVA.

Anno de 1754 .

Com oldas as licencas necessarias.

\section{RELAÇAÕ}

Sendo 5. de Agosto em que demos principio a nossa derrota, hindo S. Excellencia embarcar estava a Companhia embaixo no porto formada, e deraõ suas descargas, e depois se embarcáraõ em duas canôas, hindo primeiro a canôa de S. Excellencia com o Guia do caminho todo muito bem vestido com farda azul, e chapeo de plumas tudo agaloado, este hia piloteando, levava seis remeiros com vestia, e calçăo encarnada, e carapuça, ou barrete, com as armas de S. Excellencia abertas em prata, logo se seguia a canôa da Missaô, que hiað dois Padres da Companhia, e logo a canôa dos Officiaes da Salla, e atraz desta a canôa de guerra Capitania, em que comandava o Capitaō de Dragoens, e logo a dos criados, e atraz destas as demais de carga, nas quaes se embarcáraó 11 $3^{\circ}$. sacos de mantimento fóra o fato, e barrilame, e outras cargas mais, e atraz de todas estas a canôa Almiranta em que comendava o Tenente da Companhia, naõ deixando ficar canôa para traz, e esta ordem sempre se executou.

Partimos sendo tres horas do referido porto, e se deraõ muitas salvas, as pessoas principaes da Villa de Itéc, logo demandamos a Cachoeira Canguira Usú, que ficava duas voltas do Rio abaixo, e tem o vocabulo sua significaçaó Caveira grande, e logo Canguiramerim Caveira pequena, sendo meyo dia chegamos á pedra Itanhe engh, pedra que falla, pela huma hora a pedra $\mathrm{C}$, obaúna cara suja, pelas duas horas Itaguaçaba pedra que passa o Rio, e he Cachoeira grande fizemos parada a passar todas as canôas de duas horas, e logo fizemos pouzo na Tapera do Alcaide mór 6. de Agostossahida do pouzo 30. minutos para as sete, fomos a Pirapora Cachoeira grande, peixe que está saltando, 
de que se sirgue por cima das pedras por ser mais seguro, porque 0 canal estava muito furioso, sahimos pelo meyo dia passamos Muigiueara, buraco da Rãa, e a Cachoeira pequena, e no mesmo dia passamos os Pilós, Cachoeira aonde se afogou hum Clerigo, e tem muitas pedras, embucamos em terra a passar a Trapa, sahimos pelas 3. horas, e sendo 4. horas pouzo mato embaraçado, sete de Agosto sahida do pouzo oito horas e hum quarto, sendo tres horas passamos a Cachoeira chamada a do Gracia, por se afogar hū homem deste nome, e he Cachoeira pequena dez horas a de Peres Cachoeira pequena, tambem se afogou sendo meyo dia Capibarí Rio á direita, huma hora Serocaba Rio á esquerda fizemos parada a ajuntar as canôas, passamos a Pedreneira Cachoeira grande, e paramos na dita por ser muito má, em que custarão a passar todas as canôas, por baixo fizemos pouzo no mato. Dia oito sahida sete horas sendo tres horas Taesatuba Rio á esquerda pouzo no mato, dia oito sahida nove horas, onze horas paramos a descarregar a canôa do senhor General em huma Ilha, e logo fizemos pouzo no mato, em outra Ilha nono dia sahida do pouzo ás oito horas, sendo onze horas passamos á Cachoeira da Ilha chamada do Mato Seco, sendo huma hora passamos o Rio Peracicaba, tem dez braças de boca pouzo no mato perto do morro de Arara coara, onde tem gentio, porèm trataõ de sua lavoira, e naõ fazem mal algum aos viagantes, dia dez sahida do pouzo sete horas, sendo dez horas passamos o Ribeiraõ dos Lançoes chamado assim por ter na boca huma Cachoeira que vem da terra, e por fazer a agoa muita escuma, da que parece ao longe lançoes estendidos, terá de largo quatro braças, huma hora parada para se ajuntar as canôas para se entrar no baixio, ou cabeceira de Pintinduiba chamado estirao muito escuro, sahimos do baixio em que todas encalharaó pelas quatro horas, e fizemos pouzo no mato, quatro horas dia onze sahida sete horas Pintinduiba Cachoeira grande, que se passáraó todas as canôas com Pilotos dobrados, segunda Cachoeira do dito fizemos parada, e nos detivevos no citio de Cubas tres horas, sahimos huma hora Itaupaba de cima isto baixio, e logo a Cachoeira de Baurú, que quer dizer que Baú cahio na agoa por ser Cachoeira grande, em que antigamente sempre se perdia canôa, e tem sua sirga por ser baixio por baixo da dita Peuzo quatro horas e hũ quarto, dia treze sahida do pouzo oito horas logo se entrou na sirga q se naõ pode acabar hontē, e logo na Cachoeira de Baurúde-debaixo Pilotos dobrados, sahimos depois da dita a navegar, ás ir. horas paramos, para desẽcalhar duas canôas por tempo de huma hora, e hũ quarto sahimos meyo dia e hũ quarto passamos a Cachoeira de Maruiry merim assim chamada, sahimos pelas duas horas paramos, para descarregar primeira carga aos 32. minutos para as tres horas, fizemos pouzo sobre o Maruiry guaçú, chamada Cachoeira grande, dia quatorze sahida nove horas pelas dez entramos nas Cachoeiras, e Itaupabas que saõ baixios de muita lage, e muito grandes, e soltas, as quaes passamos em dar varias pancadas muito fortes, e logo a Cachoeira chamada Sapetuba, por ter em terra muito sapé que he palha, sahimos de todo laberinto ás onze horas 
e tres quartos paramos, para ver se algũa canôa tinha algũ perigo das quaes encalháraõ quasi todas, sahimos pela hũa hora passamos as Itaupabas, e Cachoeira das Congonhas, que he huma erva que tem muita a terra firme desta Cachoeira, de que uzao os Paulistas, como nós do nosso chá muito diuretica, e sahimos a salvamento, e fizemos pouzo quatro horas, dia quinze sahida do pouzo ás oito horas, pelas duas horas paramos, para passar a Cachoeira de Manicanguabi, chamada braço da velha, pouzo quatro horas, dia dezaseis sahida oito horas passamos a dita Cachoeira, que honte a naõ podemos passar por ser muito comprida, e hir fazendo-se noite, e paramos até passar duas canôas á sirga, que por serem pequenas naõ se meteraõ ao canal em risco de naõ aparecerem mais, sahimos pelas dez horas, de que fomos passando por huns baixios, que se chamaó a escaramuça do gato falço, por ter os cạnaes em si que parece ao vir as canôas huma contradança, onde encalhou a canôa do senhor General, embicamos depois do mayor perigo passado a esperar por elle, sendo huma hora esperamos a se ajuntar a tropa para passarmos a Cachoeira (junto de huma Ilha) chamada Tambaúcy, e significado he muyto feyo, sendo duas horas passamos Itaupabas, e comrentezas de Tambaperiria, e significado naô pode ser pernunciado, e paramos a esperar toda a tropa às quatro horas, e hum quarto passamos a Cachoeira muito grande chamada Cambajubaveya quer dizer frecha que abrio hum braço (porque o gentio atirou com ella a huma tropa, de que ferio hum homem) gastouse tempo em passar, e depois se fez pouzo dezasete dias sahida do pouzo, sete horas Rio morto pouzo ás tres horas e meya dia dezoito sahida ás sete horas às onze passamos Itaupabas da Cachoeira Abanhandava merim, que quer dizer homem que corre, ou gente que corre por ser Cachoeira grande, em que todos vaõ por terra, por isso tem este significado, ás tres da tarde passamos a dita Cachoeira com Pilotos dobrados, e fizemos pouzo sobre - salto de Abanhandava Usú, em que estivemos tres dias para haver de se vararem as canôas por terra, o varadeiro he comprido, e com grande trabalho se passaõ, a Cachoeira se despenha por pedrarias, de fórma que deita fumo, tem de altura nove braças, já tem algumas canôas hido por ella abaixo, que por causa da grande corrente que pela parte de cima há, que tem cobrado as prizoens, e tem hido pela Cachoeira abaixo, e naó se tem visto mais, que se fazem em muitos bocados, dia vinte e hum sahida de salto canôas carredas, e varadas, pelas duas horas da tarde Itaupabas, e Escaramuças, e embicamos para a sirga ás tres horas e meya sahimos das ditas sirgas, e Cachoeira da escaramuça do gato verdadeiro, com Pilotos dobrados pouzo dia vinte e tres sahida do pouzo nove horas, sendo onze horas chegamos ao descarregadouro do Itypanema, onde embicamos para serem levadas todas as cargas por terra, e as canôas hirem á sirga, todas ficáraõ por baixo do salto por toda esta tarde, e as cargas se acabáraó de passar até o meyo dia vinte e quatro a Cạchoeira supra seu significado he (salto patife) por ser muito baixo será hũa braça, no mesmo dia vinte e quatro sahimos depois de tudo carregado á huma hora, sendo duas 


\section{8}

horas Cachoeira pequena da Tha que carece de nome Itaupaba porto da huma volta do Rio, sendo quatro horas passamos as ondas grandes, Cachoeira grande q faz ondas, como o mar sendo cinco horas pouzo dia vinte e cinco sahida oito horas, sendo nove horas ondas pequenas Cachoeira grande, porèm menos ondas do que a primeira, sendo dez horas, e trez quartos passamos o funil grande Cachoeira grande, e furiosa, sirga juntamente até ás onze horas e quarenta e cinco minutos esperamos as canôas, e sahimos pela huma hora, e logo entramos ao funil pequeno, Cachoeira grande atravessáraõ algumas canôas de que estiveraõ em perigo, esperamos até ás cinco horas que passasse tudo, fizemos logo pouzo chama-se funil estas Cachoeiras, por ter, e ser canal da mesma fórma como funil na entrada largo, e sahida muito estreito, que se acazo alguma canôa naõ vai esquipada que na sahida tópa nas pedras a traveça, e logo vira, dia vinte e seis, sahida nove horas, sendo dez minutos para as dez paramos para passar a Cachoeira de Vacorituibá, lugar onde há muito palmito, he muito grande Cachoeira, todo este dia gastamos em passar esta trabalhosa Cachoeira chêa de correntezas sirgas e encalhaçoens, e fizemos pouzo, estiveraõ duas canôas em perigo por atravessar, dia vinte e sete de Agosto de caminho vinte e dois sahida ás oito horas, sendo nove horas segunda escaramuça do gato verdadeiro, sendo huma hora embicamos para passar Aracangua Merim Cachoeira, que quer dizer lugar onde se come a cabeça de Arara, por haver muita por este lugar sahimos della, e da (sic) suas sirgas pelas duas horas pouzo no mato dia vinte e oito sahida do pouzo sete horas, e sendo oito; entramos na sirga do Aracuanguá guaḉ neste salto que será de huma braça,.se gastou todo o dia a passar as canôas, e carregar, cuja carga se tirou antes que se entrasse na sirga pouzo, dia vinte e nove sahida sete horas e meya, entramos logo na sirga do Itypéla que diz salto razo, sahimos della, e fizemos logo pouzo sendo quatro horas. Naó te enfado mais amigo Leitor, com esta porèm se quizer ter a paciencia de me ouvires na segunda parte, pois nella te darei mais ampla noticia. 